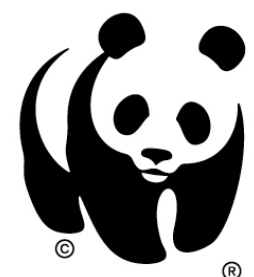

WWF for a living planet ${ }^{\circ}$

\title{
Pure Profit for Russia: Benefits of Responsible Finance
}

Edited by Ivetta Gerasimchuk, Kamila Ilyumzhinova and Alistair Schorn

Authors (in alphabetical order):

Mark Eckstein

Ivetta Gerasimchuk

Kamila Ilyumzhinova

Ekaterina Khmeleva

Georg Kraft

Jürgen Lottmann

Renat Perelet

Kevin Smith

Alistair Schorn

Evgeny Shvarts

Moscow - Frankfurt a.M. - Johannesburg, 2009 
Pure Profit for Russia: Benefits of Responsible Finance. WWF's Trade and Investment Programme report. Ivetta Gerasimchuk, Kamila Ilyumzhinova, Alistair Schorn (Eds). Moscow - Frankfurt a.M. - Johannesburg; WWF, 2009.

\section{Authors (in alphabetical order):}

Mark Eckstein - $1.4-1.6,3.4$

Ivetta Gerasimchuk - Introduction, 1.1 - 1.2, $1.4-1.6,3.2$ - 3.4, Conclusion

Kamila Ilyumzhinova - $1.3-1.4$, Chapter 2, 3.2 - 3.3, Conclusion

Ekaterina Khmeleva - 3.1

Georg Kraft - 1.3, 2.1, 3.3

Jürgen Lottmann - 1.2, 3.2

Renat Perelet -3.1

Kevin Smith - 1.3, 2.3, 3.3

Alistair Schorn - 1.5

Evgeny Shvarts $-3.2-3.3$

The purpose of this report is to serve as a post financial crisis handbook that will help both financiers and environmentalists in Russia to cooperate in establishing a 'greener' and less risky financial system in a similar manner to which this process is underway in other emerging markets such as China, Brazil and South Africa. The report provides an overview of the evolution of international mechanisms of environmental and social responsibility in the global financial sector, quantifies the scope of exposure of foreign and Russian financial institutions to environment-intensive sectors of the Russian economy, and concludes with recommendations regarding actions that might be implemented by both the Russian government and domestic financial institutions.

The report has been prepared within the framework of the project 'Integration of Environmental and Social Safeguards, Standards and Processes and the Climate Change Agenda in the Russian Finance Sector' implemented by WWF-Russia and WWF-Germany with the financial assistance of the Federal Agency for the Environment (Umweltbundesamt/UBA) under the German Federal Ministry for the Environment, Nature Conservation and Nuclear Safety (BMU), and with the support of the Russian Ministry of Natural Resources and Ecology, European Bank for Reconstruction and Development (EBRD), in collaboration with the Equator Principles Outreach Group for Russia.

\section{Reviewers (in alphabetical order):}

Dr. Sergey Bobylev - Professor in Environmental Economics, Department of Economics, Moscow State University (Moscow, Russia)

Dr. Leonid Grigoriev - Professor and Dean, Department of Management, International University (Moscow, Russia) and President, Institute of Energy and Finance (Moscow, Russia)

Dr. Theodore Panayotou - Professor in Environmental Economics, John F. Kennedy School of Government, Harvard University (Cambridge, USA) and Director and Professor, Cyprus International Institute of Management (Nicosia, Cyprus)

All rights reserved by WWF.

This report is distributed free of charge. 


\section{TABLE OF CONTENTS:}

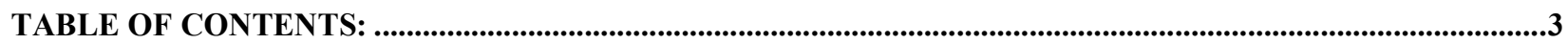

EXECUTIVE SUMMARY .......................................................................................................................................8

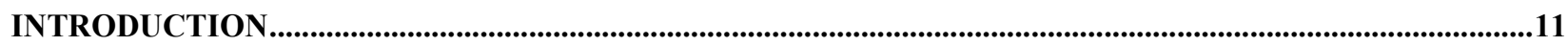

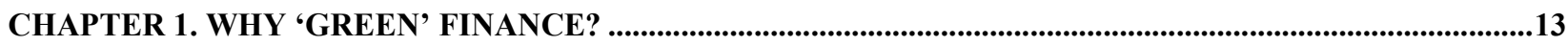

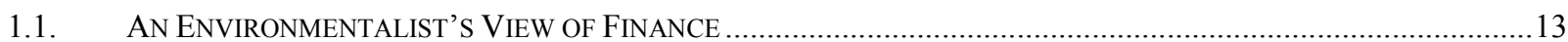

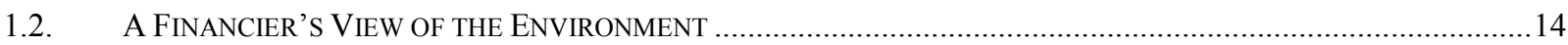

1.3. 'GREEN' FINANCIAL MECHANISMS: EVOLUTION AND EXISTING HIERARCHY .............................................17

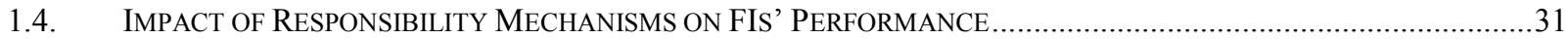

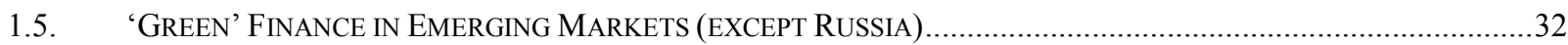

1.6. FutURe PRosPeCtS AND PRINCIPAL CHALLENGES FOR RESPONSIBLE FINANCE WORLDWIDE .........................34

CHAPTER 2. AN OVERVIEW OF THE RUSSIAN FINANCIAL SECTOR..........................................................38

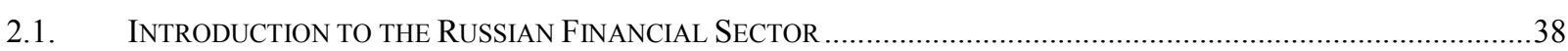

2.2. RUSSIA'S RELIANCE ON FOREIGN AND DOMESTIC FINANCE ……........................................................42

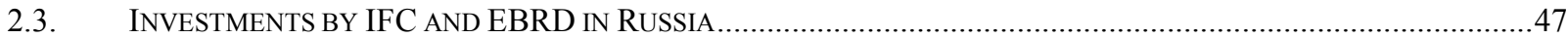

2.4. INTERNATIONAL SYNDICATED LOANS: A SECTORAL ANALYSIS ..................................................................

2.5. LOANS PROVIDED By RuSSIAN BANKS: A SECTORAL ANALYSIS ...............................................................61

CHAPTER 3. TOWARD RESPONSIBLE FINANCE IN RUSSIA ……....................................................................71

3.1. OVERVIEW OF THE EXISTING ENVIRONMENTAL ASSESSMENT PROCEDURES IN RUSSIA.................................71

3.2. RECOMMENDATIONS TO THE RUSSIAN GOVERNMENT .........................................................................74

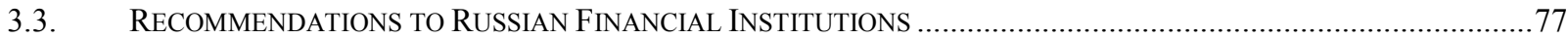

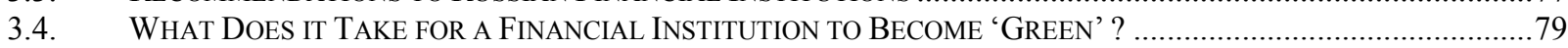

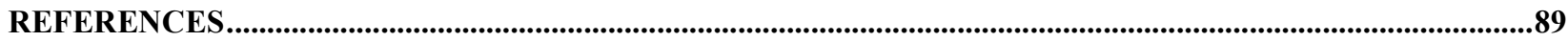

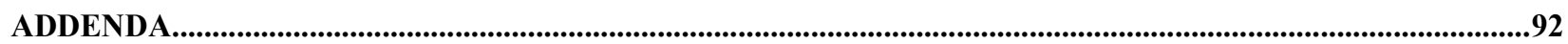

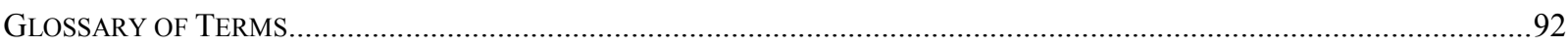

COLLEVECCHIO DECLARATION ON FINANCIAL INSTITUTIONS AND SUSTAINABILITY ............................................98

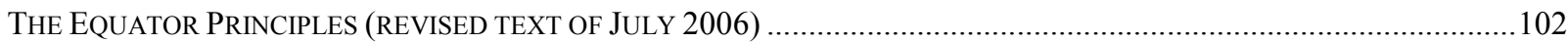

AdOPTING AND IMPLEMENTING THE EQUATOR PRINCIPLES: THE CASE OF MiZUHO CORPORATE BANK ....................109

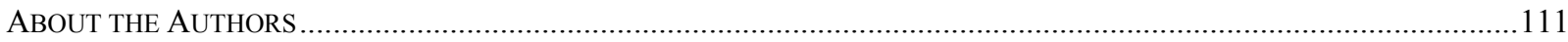




\section{List of Acronyms}

\begin{tabular}{|c|c|}
\hline ADB & Asian Development Bank \\
\hline ARRA & American Recovery and Reinvestment Act \\
\hline BRICS & Brazil, Russia, India, China, South Africa \\
\hline BRL & Brazilian Real \\
\hline CBR & Central Bank of Russia \\
\hline CDP & Carbon Disclosure Project \\
\hline CERES & Coalition for Environmentally Responsible Economies \\
\hline CSI & Corporate Social Investment \\
\hline CSR & Corporate Social Responsibility \\
\hline $\mathrm{CO} 2$ & Carbon Dioxide \\
\hline EA & Environmental Assessment \\
\hline EBRD & European Bank for Reconstruction and Development \\
\hline ECA & Export Credit Agency \\
\hline EHS & Environment, Health and Safety \\
\hline EIA & Environmental Impact Assessment \\
\hline EPs & Equator Principles \\
\hline EPFI & Equator Principles Financial Institution \\
\hline ESG & Environmental, Social and Governance \\
\hline EU & European Union \\
\hline EUR & Euro \\
\hline FFSM & Federal Financial Markets Service \\
\hline FI & Financial Institution \\
\hline FIG & Financial and Industrial Group \\
\hline FSC & Forest Stewardship Council \\
\hline G3 & Third Generation \\
\hline GDP & Gross Domestic Product \\
\hline GHG & Greenhouse Gasses \\
\hline GRI & Global Reporting Initiative \\
\hline IBRD & International Bank for Reconstruction and Development \\
\hline IFC & International Finance Corporation \\
\hline ILO & International Labour Organisation \\
\hline INCR & Investor Network on Climate Risk \\
\hline MDB & Multilateral Development Bank \\
\hline MDGs & Millennium Development Goals \\
\hline NA & Not Available \\
\hline NGO & Non-Governmental Organisation \\
\hline OECD & Organisation of Economic Cooperation and Development \\
\hline $\mathrm{PBoC}$ & People's Bank of China \\
\hline RDB & Regional Development Bank \\
\hline RUR & Russian Rouble \\
\hline SER & State Environmental Review \\
\hline SES & Social and Environmental Sustainability \\
\hline SME & Small and Medium-sized Enterprises \\
\hline SPE & Special Purpose Entity \\
\hline SR & State Review \\
\hline SRI & Socially Responsible Investment \\
\hline UK & United Kingdom \\
\hline UNEP & United Nations Environment Programme \\
\hline UNEP FI & United Nations Environment Programme's Finance Initiative \\
\hline UNFCCC & United Nations Framework Convention on Climate Change \\
\hline UN PRI & United Nations Principles for Responsible Investment \\
\hline $\mathrm{US}(\mathrm{A})$ & United States (of America) \\
\hline USD & US Dollar \\
\hline WWF & Worldwide Fund for Nature \\
\hline
\end{tabular}


[Pure Profit for Russia: Benefits of Responsible Finance]

\section{List of Tables}

Table 1. Integration of Voluntary Environmental and Social Responsibility Mechanisms in the Financial Sector of Selected OECD and OECD Candidate Countries (as of September 2009) ........ 24 Table 2a. Comparative Analysis of Internal Social and Environmental Responsibility Mechanisms of Leading Multilateral FIs 25

Table 2b. Comparative Analysis of International Social and Environmental Responsibility Frameworks Adopted by Leading FIs 27

Table 3. Comparative Analysis of Social and Environmental Responsibility Policies of Selected National Development Banks.

Table 4. Carbon Markets at a Glance. Volumes and Values in 2007 - 2008. ................................. 37

Table 5. External Debt of the Russian Federation in 2006 - 2008 ............................................. 42

Table 6. Funding Sources of the Accumulated Debt of Russia's Corporate Sector as of 30 October 2008

Table 7. Largest Syndicated Loans in Russia Classified by Mandated Lead Arrangers (January 2006

- July 2009)

Table 8. All Project Financing Transactions with the Participation of Russian Borrowers from

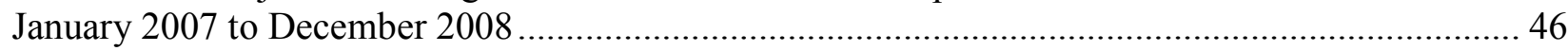

Table 9. IFC Loans to Russian Borrowers ................................................................................. 48

Table 10. EBRD Loans to Russian Borrowers............................................................................... 50

Table 11. Ten Largest Loans in the Russian Chemicals, Mining, Machinery and Manufacturing

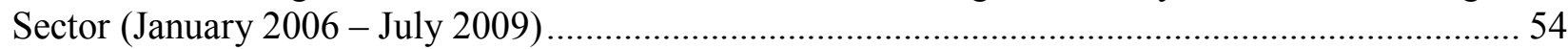

Table 12. Ten Largest Loans in the Russian Oil and Gas Sector (January 2006 - July 2009) .......... 55

Table 13. Ten Largest Loans in the Russian Utilities Sector (January 2006 - July 2009) ............... 56

Table 14. Ten Largest Loans in the Russian Real Estate, Construction and Property Sector (January

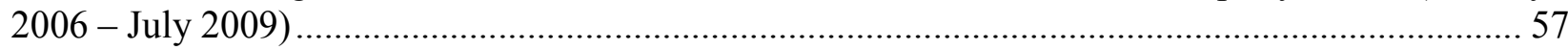

Table 15. Ten Largest Loans in the Russian Transport and Telecommunications Sector (January

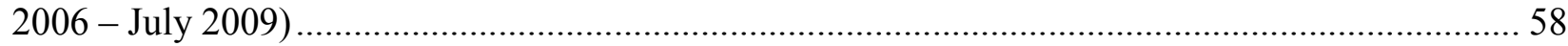

Table 16. Ten Largest Loans in the Russian Agriculture, Food and Forestry Sector (January 2006 -

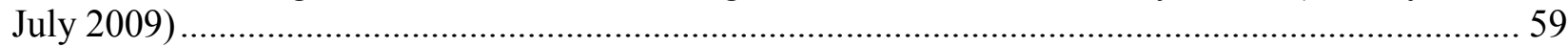

Table 17. Ten Largest Loans in the Russian Finance Sector (January 2006 - July 2009) ............... 59

Table 18. Russia's Top 25 Banks - Lending to Environment-Intensive Industries.......................... 62

Table 19. Environmental Decision-Making throughout Investment Project Life Cycle .................. 72 Table 20. Comparative Analysis of Russian Environmental Legislation and IFC/EBRD/Equator Principles Frameworks of Environmental and Social Responsibility ........................................... 73

Table 21. Global Green Stimulus and Green Investments as of 1 July 2009................................... 76 


\section{List of Figures}

Figure 1. Key Reasons Why Banks Consider Sustainability Issues .......................................... 16

Figure 2. Reactive Vs. Strategic Corporate Social Responsibility.............................................. 17

Figure 3. The Dynamic Business Case for Responsible Banking in Emerging Markets .................. 31

Figure 4. Structure of the Accumulated Debt of Russia's Corporate Sector as of 30 October 2008,

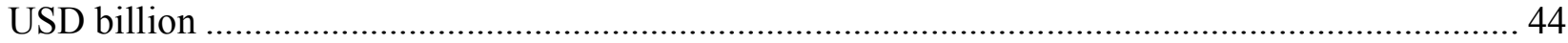

Figure 5. Domestic Lenders to the Russian Construction, Real Estate and Project Finance Sector in

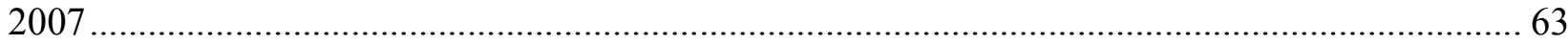

Figure 6. Domestic Lenders to the Russian Manufacturing (Excluding Light Industry), Metallurgy

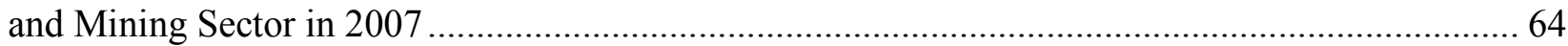

Figure 7. Domestic Lenders to the Russian Electricity Sector (Including Hydro and Nuclear Power)

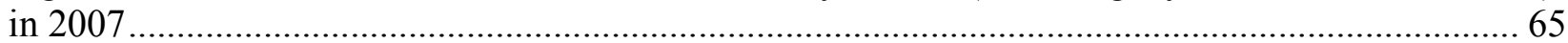

Figure 8. Domestic Lenders to the Russian Oil, Gas, Coal, Fuel and Chemical Sector in 2007 ....... 66

Figure 9. Domestic Lenders to the Russian Transport and Communications Sector in 2007........... 67

Figure 10. Domestic Lenders to the Russian Agricultural Sector (Including Food, Forestry and

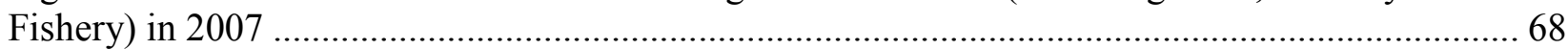

Figure 11. Domestic Lenders to the Russian Defense Sector in 2007 .......................................... 69

Figure 12. 'Intangible' Lending in Russia: Domestic Lenders to the Russian Financial Sector in

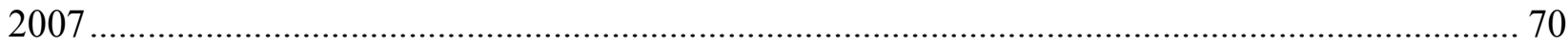

Figure 13. Integrating ‘Green’ Responsibility Standards from Scratch: a Generic Roadmap for

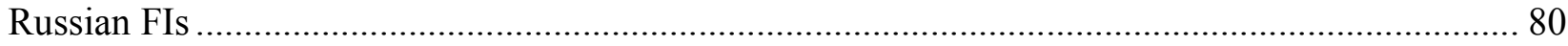

Figure 14. Internal Consultations among FI's Teams for Making Responsible Decisions............... 83

Figure 15. The Hierarchy of Options to Address Environmental and Social Risks......................... 84

Figure 16. Four Criteria for an Efficient Public Consultation under a FI's Responsibility Framework 
This report forms part of a series of studies by WWF's Trade and Investment Programme, which aims at identifying and cooperating with actors in the key emerging economies (Brazil, Russia, India, China, South Africa and others) in order to promote sustainable trade and investment internationally. The Programme examines the scope that exists for these countries to become leading exporters of, and investors in, sustainable goods and services, whilst emerging as key actors in promoting a proactive international sustainable development agenda.

The report has been prepared within the framework of the project 'Integration of Environmental and Social Safeguards, Standards and Processes and the Climate Change Agenda in the Russian Finance Sector' implemented by WWF-Russia and WWF-Germany with the financial assistance of the Federal Agency for the Environment (Umweltbundesamt/UBA) under the German Federal Ministry for the Environment, Nature Conservation and Nuclear Safety (BMU), and with the support of the Russian Ministry of Natural Resources and Ecology, European Bank for Reconstruction and Development (EBRD), in collaboration with the Equator Principles Outreach Group for Russia.

The authors extend their special thanks to Elias Sabeh for his assistance with data analysis and to Alexandra Hausladen and Janine Licare for proof-reading the English text of the report. 
[Pure Profit for Russia: Benefits of Responsible Finance]

\section{EXECUTIVE SUMMARY}

From being an exotic addition to risk management toolkits in the 1990s, environmental and social standards have over the past decade become a mainstream concern for financial institutions in developed countries, and furthermore exhibit an ever-increasing importance in emerging markets such as China, Brazil and South Africa. Moreover, sound environmental risk management practices and the application of responsibility benchmarks in the financial sector are also adherent to membership of the Organisation for Economic Cooperation and Development (OECD), which unites the most economically developed nations of Europe, North America and Australasia.

These mechanisms for responsible public finance include amongst others the World Bank's Operational Manual, the Performance Standards of the International Finance Corporation, the OECD's Recommendation on Common Approaches on the Environment and Officially Supported Export Credits and similar guidelines of regional development banks. For responsible private finance, they include the Equator Principles (signed by over 60 leading banks and covering 71 percent of the total project finance provided to emerging markets in 2007), the United Nations Principles for Responsible Investment (signed by over 510 financial institutions with total assets under management of over USD 18 trillion) and various other benchmarks.

Although varying in their scope of application, all these responsibility mechanisms within the financial sector hold a similar objective, namely that of limiting lending to or investment in environmentally and socially controversial projects, due to the additional risks associated with such projects. The responsibility frameworks also assist financial institutions to pursue new market opportunities created by low carbon government regulations and customer demand, particularly in the context of rapidly developing markets for carbon emissions certificates, and the significant 'green' components of the economic stimulus packages implemented by various governments during $2008-2009$.

The impact of sustainability benchmarks across a range of financial products and services is becoming increasingly apparent - from project and export finance to corporate loans, private equity and institutional investments. Due to the 2008/9 financial crisis and the resultant increases in public and government scrutiny of the financial sector worldwide, many financial institutions are in the process of redesigning and improving their risk management tools and approaches. By widening the scope of risk management to include environmental, social and governance issues, sustainability can be a major contributor to a more resilient and responsible global financial system.

As Russia becomes more integrated into the global economy and seeks membership of the OECD, the integration of environmental and social responsibility standards into the Russian financial sector appears to be a question of "when" rather than "if". As of October 2009, however, no Russian financial institution has adopted any of the internationally recognised responsibility benchmarks, which raises the question regarding the cost of such inaction to the Russian financial sector and to the country's economy as a whole.

Analysis of loans provided to environment-intensive industries in Russia by multinational financial institutions - the International Finance Corporation (IFC) and the European Bank for Reconstruction and Development (EBRD), - as well as by foreign private banks and domestic banks, suggests that the application of voluntary responsibility mechanisms can prove to be an effective tool for both protecting the environment and enabling Russian financial institutions to minimise their risks and increase their international and domestic competitiveness. Foreign capital markets are likely to remain the major source of funding for extractive industries in Russia (specifically mining, the extraction of coal, oil and gas, etc). At the same time, Russian banks are the principal providers of 
financing to sectors that play the most crucial role in improving energy efficiency in the Russian economy (namely construction, real estate and electricity generation) and efficient land use and conservation of the country's biodiversity (farming, forestry and fishery). The most lucrative clients in Russia, including oil and gas companies, tap into international financial markets and are therefore accustomed to applying the international responsibility mechanisms required by these investors. There is therefore no evidence to suggest that avoidance of international responsibility frameworks will make Russian financial institutions somehow more attractive to potential clients than their foreign competitors.

On the contrary, the experiences of IFC and EBRD are testament to the fact that environmentally responsible and progressive investments are possible in Russia, and that energy efficiency measures in particular can prove extremely attractive for financial institutions from a commercial point of view. According to the IFC's annual client survey conducted in 2006, the third most important factor for clients in terms of entering into a partnership with IFC was the assistance that the organisation provides in managing environmental and social issues. The potential market for energy efficiency solutions in Russia is a huge one, and the benefits to be gained, in terms of carbon emissions reductions and the resulting benefits for the climate change agenda, are equally significant. There also exists significant potential for investments in renewable energy in Russia, particularly in wind power. Similarly, waste treatment is another area which will need to be addressed by Russian companies if they are to increase their international competitiveness.

In order to integrate environmental and social responsibility benchmarks in the Russian financial sector, a joint effort of the Russian government, domestic financial institutions and affected stakeholders is required. Firstly, the 'greening' process of the Russian financial system can be assisted by the clear articulation of messages regarding environmental safeguards on the part of the Russian government, particularly with respect to the major Russian state-owned banks (VEB, Sberbank, VTB, Russian Agricultural Bank and Gazprombank). Secondly, the harmonisation of Russian legislative requirements regarding environmental impact assessment procedures with those of international financial institutions will assist Russian borrowers to avoid unnecessary costs related to duplication of effort involved in compliance with two separate sets of requirements. Thirdly, the provision of state funds, including stimulus financing, for industrial projects should target low carbon and resource-efficient projects in order to support the modernisation of the economy in a similar fashion to the 'green' stimulus schemes adopted in the US, EU countries, China, South Korea and a number of other states. Finally, in order to facilitate stakeholders' engagement and efficient decision-making, representatives of government environmental agencies and civil society organisations should be involved in the approval process for loans by the major Russian state-owned banks to environment-intensive projects.

Following a similar logic, Russian financial institutions can commence their 'greening' process by reviewing the environmental and social risks associated with their existing and potential loans and initiating an open and transparent dialogue with stakeholders. These activities should be integrated into the core operations of institutions through the creation of internal sustainability teams and the development of a responsibility strategy supported by operational toolkits such as screening checklists for industry sectors, manuals, action and client monitoring plans, and compliance and grievance procedures. In developing these internal mechanisms, Russian financial institutions could make extensive use of international sustainability practices in the financial sector. Collaboration with customers in the areas of energy- and resource-efficiency, and in the identification of client needs and opportunities in these fields offers a further value addition that sustainability teams can provide to financial businesses. Finally, Russian financial institutions might launch various 'green office' initiatives, for example ISO 14000 certifications of internal environment management 
systems, the use of Forest Stewardship Council certified and recycled paper, the implementation of energy (and cost) saving schemes such as teleconferencing instead of business travel, and the offsetting of carbon footprint from office activities and employees travel through the purchase of tradable renewable energy certificates or support for sustainable afforestation projects.

From the viewpoint of WWF, the most realistic scenario for the development of responsible finance in Russia is for a few proactive financial institutions in the country to take the lead in the area of environmental and social sustainability, and thereby 'turn the tables', making other players follow in order to retain competitiveness and market share. This report is intended to assist these anticipated market leaders in gaining the maximum benefit from a collective of international experience in responsible finance. 
[Pure Profit for Russia: Benefits of Responsible Finance]

\section{INTRODUCTION}

\section{Ivetta Gerasimchuk}

WWF, the Worldwide Fund for Nature, is one of many organisations expressing the view that both the financial and environmental crises can and should be addressed simultaneously through a wellbalanced set of sustainability measures. This vision is shared by a number of governments throughout the world that have during 2008 - 2009 included significant 'green'1 components into their economic stimulus packages, varying from 33.4 percent in China's 'New Deal' to 12 percent in the USA expenditures under the American Recovery and Reinvestment Act. $^{2}$

Financial institutions (FIs) play a major role in providing investment funding to support such 'green' points of economic growth and employment creation as development of low carbon infrastructure (energy-efficient buildings, renewable energy resources, rapid ground transit systems as opposed to air transportation, etc), the management of ecosystem goods and services and 'green' research and development. In particular, in 2005 the G8 Summit held at Gleneagles (Scotland) mandated the World Bank and regional development banks to increase their dialogue with borrowers on energy efficiency issues, in order to facilitate climate change mitigation and adaptation measures.

Furthermore, an additional dimension of the interrelation between the financial sector and the environment concerns the valuation of risk. The current myopic attitude towards various types of risks (credit, social, environmental, etc) and attempts to externalise these beyond national borders and short time frames have been amongst the primary contributors to both the ongoing environmental degradation and the credit crunch of 2008 - 2009. In order to aid the recovery of the world economy from the financial crisis it is essential that the reforms implemented in the international financial system are based on longer term considerations and that they actively take steps to avoid risks externalisation through the implementation of prudent management policies and practices.

In this regard, WWF's experience in both the countries of the Organisation of Economic Cooperation and Development (OECD) and key emerging market economies such as Brazil, China and South Africa, demonstrates that internationally recognised mechanisms of environmental and social responsibility can be an effective tool for both protecting the environment and enabling international and national FIs to minimise their risks and increase their competitiveness. In the case of public finance, these mechanisms include, amongst others, the World Bank's Operational Manual, the Performance Standards of the International Finance Corporation, the OECD's Recommendation on Common Approaches on the Environment and Officially Supported Export Credits and similar guidelines of regional development banks. For private finance, they include the Equator Principles, which have been adopted by over 60 leading banks, the UNEP Financial Initiative, the United Nations Principles for Responsible Investment, as well as a number of other benchmarks.

\footnotetext{
1 For all terms marked in Italic, see definitions in the Glossary of Terms in the Addenda section of the report.

2 Barbier, E. (2009). 'Rethinking the Economic Recovery: A Global Green New Deal.' Report prepared for the Economics and Trade Branch, Division of Technology, Industry and Economics, UNEP. Geneva. P. 4. http://www.unep.org/greeneconomy/docs/GGND-Report-April2009.pdf (accessed on 30 Oct. 2009) The Gleneagles Communiqué (2005). P. 8. http://www.unglobalcompact.org/docs/about the_gc/government_support/PostG8_Gleneagles_Communique.pdf (accessed on 30 Oct. 2009)
} 
Despite the fact that, as of October 2009, no Russian FIs has become a signatory to any of the aforementioned internationally recognised responsibility benchmarks, WWF has been both expecting and observing a growing interest in these standards within the Russian financial sector. In this regard, Russian FIs are expected to undergo the same evolution as their counterparts in the West and some emerging markets; from responsive corporate social responsibility (CSR) to information disclosure, to strategic CSR as a competitiveness tool.

Both individually designed social and environmental policies and internationally recognised benchmarks can assist Russian FIs to not only mitigate and overcome the negative effects of the 2008/9 financial crisis, but also to secure a stronger and more sustainable - in all senses of the word - footing in the post-crisis world.

The purpose of this report is to serve as a post financial crisis handbook that will assist both financiers and environmentalists in Russia to cooperate in establishing a 'greener' and less risky financial system. Due to the predominant role of commercial banks and the much less significant role of investment banks, private equity funds and other types of financial service providers amongst domestic FIs in Russia, the report is primarily focused on sustainable lending practices, whereas as mentioned above, internationally recognised environmental and social responsibility standards have emerged and been adopted in all areas of financial activities.

Chapter One of the report provides an overview of the evolution and hierarchy of international mechanisms related to the environmental and social responsibility of FIs as well as the application of these mechanisms in both OECD countries and emerging economies such as China, Brazil and South Africa.

Chapter Two briefly describes the Russian financial system and provides a classification of the Russian FIs from the viewpoint of their attitude to environmental and social issues. Particular attention is paid to the feasibility of 'green' finance schemes in Russia, as evidenced by the successes of the IFC and EBRD energy-efficiency programs. For the purposes of establishing the scope of the creditors' environmental responsibility, Chapter Two also includes a sectoral analysis of the loans that foreign and domestic FIs have provided to the Russian environment-intensive industries.

Chapter Three reviews the compatibility of the international mechanisms to promote environmental and social responsibility within FIs with existing Russian legislation, and provides recommendations for action to both the Russian government and domestic FIs.

The report concludes with an assessment of possible scenarios for the integration of environmental and social responsibility mechanisms into the Russian financial sector. The Addenda section contains materials that aim to assist readers in forming a comprehensive picture of the sustainable finance sector. These include a glossary of terms, the texts of the Collevecchio Declaration on Financial Institutions and Sustainability and the Equator Principles as well as a first-hand description of the experience of adopting and implementing the Equator Principles, written by Mr. Osamu Odawara, Senior Vice President and Head of the Sustainable Development Department at Mizuho Corporate Bank. 
[Pure Profit for Russia: Benefits of Responsible Finance]

\section{CHAPTER 1. Why 'Green' Finance?}

\subsection{An Environmentalist's View of Finance}

\section{Ivetta Gerasimchuk}

In virtually every instance of an investment project that exhibits a controversial social and environmental profile, the question that environmental organisations will inevitably ask concerns the sources of funding for the project, and therefore the financial institutions (FIs, i.e. lenders, investors, asset managers, insurers, etc) involved. The degree of interrogation often depends to some extent on the profile of the environmental organisations involved and the freedom they have to raise their concerns regarding the environmental impact and footprint of a particular project.

In this, as well as many other respects, the positions of environmental organisations vary from radical opposition to any exploitation of natural resources for commercial gain to a cooperative approach which seeks to achieve a 'win-win' outcome for both the environment and the economy wherever possible. In the majority of instances, WWF will adopt the collaborative approach based upon the assumption that environmental and economic objectives can be reconciled. Therefore, WWF will maintain a constructive dialogue with stakeholders from various sectors by liaising with the project promoters and investors in question as well as by seeking to build coalitions with other civil society interest groups.

The most significant example of 'green' $N G O s$ coalition-building with the objective of conveying environmental concerns and requirements to financial institutions is the Collevecchio Declaration on Financial Institutions and Sustainability that was released through Banktrack and endorsed by over 100 NGOs including WWF, UK, and WWF Italy in January 2003. This Declaration calls for FIs to implement 6 principles (see Addenda for the full version of the text) regarding sustainable solutions for the environment and society into their operational and financing procedures. It also demands that environmental and social issues and their sustainable mitigation be considered as important for financial institutions as shareholder value maximisation and customer satisfaction. Less than half a year after its adoption in June 2003, the financial services community responded to the Collevecchio Declaration by issuing the Equator Principles (EPs, see Addenda for the full version of the text), which govern environmental responsibility and sustainability in the finance sector. These Principles were positively received by the international NGO community as a first step towards meeting their demands. At the same time, however, many environmentalists and NGOs feel the Principles can and should go even further by defining certain "no-go areas" in industry as well as by promoting greater environment-related information disclosure on the part of signatories. Despite considerable and commendable progress in the area of environmental and social responsibility on the part of FIs, the messages of the Collevecchio Declaration remain valid, especially in the context of the 2008/9 financial crisis.

In general WWF, along with many other environmental organisations, may find itself in three distinct situations vis-à-vis FIs. The first is one in which environmentalists criticise lenders and investors for not complying with existing legal requirements and voluntary responsibility commitments. This situation arises most frequently with regard to information disclosure and participation in public hearings during the course of Environmental Impact Assessments (EIAs). For example, this was the case for two large projects in Russia, namely Sakhalin II and Boguchanskoe hydropower dam. In extreme cases, investors and lenders might even try to avoid dialogue with local communities and NGOs by setting up fake stakeholder organisations that receive money for approving environmentally and socially controversial solutions in order for EIA requirements to appear to be met. 
The second situation is one in which 'green' NGOs appeal to international lenders as auxiliary regulators of the projects, since it is sometimes the case that international FIs' requirements regarding EIAs and other social and environmental implications of investment projects are more stringent than local regulations. This is often the case in non-OECD countries, including Russia. In such circumstances, collaboration between environmental organisations, on the one hand, and banks and export credit agencies (ECAs), on the other, can prove to be particularly efficient in creating pressure on the project promoters to implement more environmentally sustainable solutions and processes. Environmental NGOs are therefore generally well aware of the important role that banks and other FIs can play in nature conservation.

The third instance of interaction between environmentalists and FIs is in the form of partnerships in which 'green' NGOs will actively assist lenders and investors to improve their responsibility policies and, in some instances, discover new competitiveness strategies such as operating in carbon credits markets or funding renewable energy.

As in any relationship, the success of interactions between 'green' NGOs and financial institutions depends on the level of mutual trust and the commitment of both parties to maintaining the dialogue.

\subsection{A Financier's View of the Environment}

\section{Ivetta Gerasimchuk and Jürgen Lottmann}

As financial markets are generally highly volatile, banks and asset managers operate according to very short time frames and their planning horizon seldom exceeds the immediate future. For example, for such risk measure as value at risk (VAR), the two most common parameters are a oneday and a two-week time horizon. In this sense, FIs are perhaps the most myopic of business organisations by nature of their activities. Since environmental and social responsibility is usually a function of planning horizon and strategic management, ${ }^{4}$ it is understandable that institutional lenders were the last organisations in the business world to recognise that they have any environmental and social responsibility at all - in fact, until the $1980 \mathrm{~s}$, banks would argue that such responsibility lies solely with borrowers.

At the same time, environmental issues, including the increasingly influential impacts of climate change, have direct impact on banks' core business. As a result, banks and other FIs have come to understand the necessity to develop and embrace their own environmental, health and safety (EHS) standards to evaluate and mitigate various types of risks, including the following:

- Reputational risks. Pressure from civil society organisations on international FIs and large private banks were amongst the principal drivers for their adoption of responsible policies during the 1980s and 90s. In a globalising world, even banks and investors in countries with weak civil society institutions must take into account pressure from international environmental organisations.

- Probability of default. Risks related to EHS may disturb the operations of a bank's customer and therefore the ability of that customer to repay any loans that may have been granted. For institutions financing environmental investments such as waste water treatment plants or solid waste disposal, environmental standards are particularly relevant since any changes or lack of compliance to these standards will directly affect the performance and revenue of the project as well as its repayment ability. However the probability of default is

\footnotetext{
${ }^{4}$ Gerasimchuk, I./ Герасимчук, И. (2007). 'Environmental Practice of Transnational Corporations / Экологическая практика транснациональных корпораций.' WWF Russia, $\quad$ Moscow. $\quad$ Pp. $66 \quad-\quad 68$. http://wwf.ru/data/pub/gerasimchuk.pdf (accessed on 30 Oct. 2009)
} 
not limited to environmental investments: It is instead a much broader issue that includes possible negative impacts from litigation in case of the borrower's violation of environmental legislation. To avoid these risks, international and OECD-based financial institutions often establish their own EIA procedures and requirements, particularly in emerging economies.

- Political and regulatory risks. For FIs, maintaining good relations with national and regional governments includes supporting public policy relating to EHS standards, sometimes in anticipation of the introduction of more stringent regulation in the future. This is particularly the case for current and future regulatory measures relating to climate change. Greenhouse gas emissions are an established international issue governed by the United Nations Framework Convention on Climate Change (UNFCCC). Following the UNFCCC Conference to be held in Copenhagen, Denmark in December 2009, which will negotiate a new multinational greenhouse gas reduction treaty to replace the current Kyoto Protocol with effect from 2012, it is expected that a range of new emissions reduction obligations will be put in place for many of the signatory nations, including high-emitting emerging markets such as China, India, Russia and South Africa. In such circumstances, a proactive approach to energy efficiency and the deployment of renewable energy technologies will definitely be of benefit to banks and their customers.

- Devaluation of collateral. Such a risk would occur in instances of environmental malperformance in the case of business enterprises or of environmental contamination in the case of real estate. Assuring the value of collateral has proven to be one of the earliest and most effective motivations for banks in OECD countries to engage in environment-related activities. However, the evaluation of environmental risks for collateral is highly dependent on government action since environmental performance is generally measured according to standards developed and enforced by national government requirements, albeit in most cases in accordance with internationally accepted norms.

- Lost market opportunities. Certain types of international refinancing are available only when accompanied by a commitment to EHS standards. In other instances, sound environmental and social policies help banks to differentiate themselves from their competitors and thereby increase their competitiveness in terms of improved access to both finance and clients.

According to the survey conducted by the International Financial Corporation, all of these factors have in the recent past played an important role in promoting the integration of social responsibility mechanisms into the practices of banks thorough the world (Figure 1). 


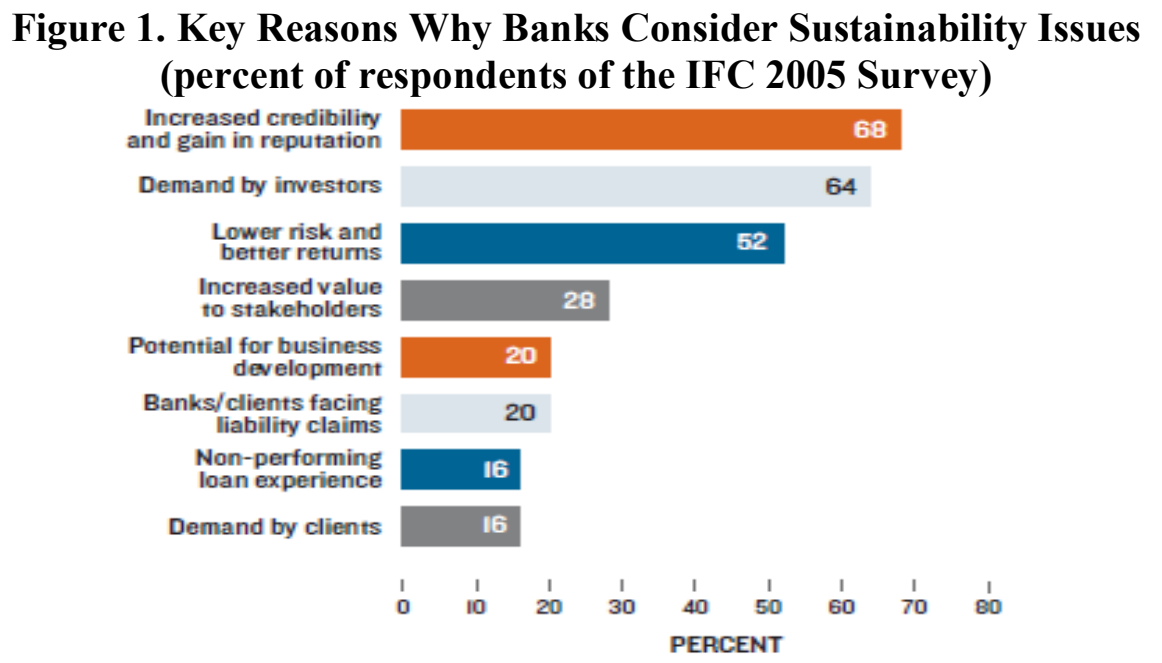

Source: IFC (2007). 'Banking on Sustainability. Financing Environmental and Social Opportunities in Emerging Markets.' IFC, Washington. $\quad$ P. 12. http://www.ifc.org/ifcext/enviro.nsf/AttachmentsByTitle/p_BankingonSustainability/\$FILE/FINAL_IFC_BankingOnSu stainability web.pdf (accessed on 30 Oct. 2009)

In view of the ongoing development of national and international environmental regulations and 'real-time' oversight by civil society organisations, the approach of international financial institutions and OECD-based lenders and investors to EHS issues has evolved from reactive corporate social responsibility (CSR) to strategic CSR as a tool to enhance competitiveness (Figure 2).

Over the past ten years, the financial industry has coined a number of sophisticated terms to describe its emerging social and environmental responsibility including, but not limited to: corporate social responsibility (CSR), corporate social investment (CSI), socially responsible investments (SRI), environmental, social and governance (ESG) issues, and social and environmental sustainability (SES). In general, the notion of social and environmental responsibility on the part of FIs can be viewed as having either a broad or a narrow scope. In the first instance, a FI that exhibits a broad approach is one that recognises the environmental and social risks inherent in projects to which it provides finance, implements systems to effectively manage and mitigate those risks. The narrow definition of responsible finance applies to FIs that specialise in financing socially and environmentally targeted projects such as social housing, energy efficiency, sanitation, etc, often providing loans to these projects at a rate lower than the market average.

It would appear that, in a globalizing world, social and environmental responsibility of FIs is currently driven primarily by established Western norms and standards, but this is also the path on which banks in Brazil, South Africa, China and a number of other emerging economies have already embarked. As a result, the question regarding the possibility of Russian FIs doing the same appears to be one of "when" rather than "if". 
Figure 2. Reactive Vs. Strategic Corporate Social Responsibility

\begin{tabular}{|l|l|l|}
\hline Generic Social Impacts & Value Chain Social Impacts & $\begin{array}{l}\text { Social Dimensions of } \\
\text { Competitive Context }\end{array}$ \\
\hline Good Citizenship & $\begin{array}{l}\text { Mitigate harm from value } \\
\text { chain activities }\end{array}$ & $\begin{array}{l}\text { Strategic philanthropy that } \\
\text { leverages capabilities to }\end{array}$ \\
\hline REACTIVE CSR & improve salient areas of \\
\hline S & Transform value-chain & \\
\hline
\end{tabular}

Source: Porter, M. and M. Kramer (2006). 'Strategy and Society: the Link between Competitive Advantage and Corporate Social Responsibility.' Harvard Business Review, Issue 84(12). Pp. 78 - 92.

\section{3. 'Green' Financial Mechanisms: Evolution and Existing Hierarchy}

Kevin Smith, Kamila Ilyumzhinova and Georg Kraft

In terms of project finance and corporate loans practices, there appears to exist an established hierarchy of FIs in that innovations regarding these practices are usually incubated, tested, and first implemented by the World Bank / International Finance Corporation (IFC), then by regional development banks (RDBs) such as European Bank for Reconstruction and Development (EBRD) and the Asian Development Bank (ADB), and finally by multinational private banks and national public and private banks - generally primarily in OECD and then in non-OECD countries. This hierarchy also generally exists with regard to the social and environmental standards of FIs (Table 1).

\section{Public Finance}

The World Bank Group published their first 'Environmental Guidelines' in 1988, and these have been in an almost constant state of review and improvement ever since. The World Bank, or more specifically the International Bank for Reconstruction and Development (IBRD), which, together with the International Development Association (IDA), is commonly referred to as "The World Bank' within the World Bank Group, uses a set of Operational Policies to guide its actions and procedures in order to achieve its developmental objectives. These Operational Policies are enshrined in the World Bank's Operational Manual, ${ }^{5}$ and from these, ten key policies have been prioritised due to their importance in the minimisation and mitigation of environmental and social impacts. These ten policies are known as the Safeguard Policies and are defined as: Environmental Assessment; Natural Habitat; Forests; Pest Management; Physical Cultural Resources; Involuntary Resettlement; Indigenous Peoples; Safety of Dams; International Waterways; and Disputed Areas.

A further document that complements the Safeguard Policies is the World Bank/IFC's Pollution Prevention and Abatement Handbook ${ }^{6}$, which in itself is an important and internationally recognised set of guidelines on the subject.

\footnotetext{
${ }^{5}$ The constantly updated Operational Manual is available on http://www.worldbank.org/opmanual

${ }^{6}$ World Bank and IFC (1999). 'Pollution Prevention and Abatement Handbook: Toward Cleaner Production.' World Bank and IFC, Washington D.C. http://www.ifc.org/ifcext/sustainability.nsf/AttachmentsByTitle/p_ppah/\$FILE/PPAH.pdf (accessed on 30 Oct. 2009)
} 
As it is the World Bank Group's private sector branch, the International Finance Corporation (IFC) is of major interest to this review. The IFC has implemented a Policy on Social and Environmental Sustainability ${ }^{7}$ which outlines the Corporation's role in terms of promoting social and environmental sustainability (SES). This Policy (along with an accompanying Policy on Disclosure) provides an overarching framework for the consideration of environmental and social issues in IFC operations, and compliance in this regard is defined according to eight Performance Standards ${ }^{8}$ that are used in conjunction with the SES policy. These Performance Standards cover the following key areas of environmental and social risks: Social and Environmental Assessment and Management System (which defines the process for assessing social and environmental risks and management capacity that must be evident within the client company); Labour and Working Conditions; Pollution Prevention and Abatement; Community Health, Safety and Security; Land Acquisition and Involuntary Resettlement; Biodiversity Conservation and Sustainable Natural Resource Management; Indigenous Peoples; and Cultural Heritage.

Any project to be funded through the IFC needs to comply with the performance requirements defined in these Standards (although compliance may not be required as a condition of disbursement of funds - provided that there exists an agreed and time-bound action plan to address any deficiencies or compliance failures).

Following the practices of other World Bank Group institutions, the IFC requires environmental and social screening to be part of its project appraisal process or Environmental Assessment (EA). Projects are defined as Category A, B, or C depending on their potential impacts.

Category A projects are assessed as having the potential for significant adverse social or environmental impacts that are diverse, irreversible or unprecedented. These projects are therefore required be rigorously scrutinised through an extremely thorough EA. An in-depth Environmental Impact Assessment (EIA) is one of the EA tools utilised when dealing with a Category A project. The EIA needs to contain an Environmental Management (or Action) Plan, which outlines the actions that are to be taken to counteract or mitigate potential negative environmental impacts. Borrowers are required to set up an independent environmental advisory board for extremely risky projects.

Category B projects hold potentially adverse social or environmental impacts that are not as grievous or large in scope as those of Category A projects. Such impacts are generally site-specific and few in number, and are more easily addressed through mitigation measures than Category A impacts. EA procedures for Category B projects are dependant on the scope and severity of environmental and social impacts.

Finally, Category $\mathrm{C}$ projects are assessed as having zero or minimal social and environmental impacts.

Importantly, the IFC requires that financial institutions taking loans from the Corporation and lending these funds as intermediaries also implement environmental assessment and management mechanisms equivalent to its own.

Another integral element of IFC social and environmental policies is the disclosure of information regarding potential social and environmental impacts to all stakeholders who may be affected by the

\footnotetext{
${ }^{7}$ IFC (2006). 'International Finance Corporation's Policy on Social \& Environmental Sustainability.' IFC, Washington D.C.

http://www.ifc.org/ifcext/sustainability.nsf/AttachmentsByTitle/pol_SocEnvSustainability2006/\$FILE/SustainabilityPoli cy.pdf (accessed on 30 Oct. 2009)

${ }^{8}$ Ibidem.
} 
proposed project, as well as ongoing consultation with these stakeholders. This consultation and disclosure process is to be carried out firstly as part of the Environmental Impact Assessment (EIA) prior to the commencement of the activities in question, and then is to be continued throughout the lifespan of the project. The consultation of and consent from indigenous peoples who are affected by a proposed project is of major importance here. A further issue of high polarity is land acquisition and involuntary resettlement which needs to be and is addressed in both sets of standards. The standards also recognise the irreplaceable importance of sites of cultural heritage. For all of the above, effective and accessible grievance mechanisms are to be established by IFC clients for affected communities. Similar grievance mechanisms need to be introduced for workers working on the project to have the opportunity to complain about labour rights issues.

Apart from the World Bank Group and IFC, which operate all over the world, a number of regional development banks (RDBs), such as the European Bank for Reconstruction and Development, African Development Bank, Asian Development Bank, Black Sea Trade and Development Bank, Inter-American Development Bank, Islamic Development Bank and some others also have environmental and social policies in place. These policies vary widely in the scope of their stringency and accountability requirements. Among these RDBs, the European Bank for Reconstruction and Development (EBRD) is probably recognised as the most environmentally responsible and aware, since it replicates the majority of the World Bank / IFC mechanisms of responsibility such as screening and classification of projects, information disclosure and public consultations, and preferential lending to 'green' clients, etc (Table 2a).

A further international guideline that utilises the World Bank / IFC standards is the OECD's Recommendation on Common Approaches on the Environment and Officially Supported Export Credits (adopted in 2003, revised in 2007) ${ }^{9}$. These guidelines apply to Export Credit Agencies (ECAs) and outline the process of environmental review that should take place prior to granting export credit. Given the major role played by ECAs in international finance, these Common Approaches provide opportunities for the application of the World Bank standards and other international environmental guidelines.

At the level of national development banks, many such organisations, located both in OECD and non-OECD countries, have articulated their social and environmental responsibility policies using the toolkit pioneered by the World Bank and IFC (see Table 3).

Increasingly, many of the public FIs described above provide significant levels of funding to projects categorised as 'green', particularly in the areas of energy efficiency and renewable energy development (see Section 2.3 for an overview of the relevant activities of IFC and EBRD in Russia). In particular, in the context of the financial crisis, national development banks often serve as conduits for investments arising from stimulus packages, some of which include considerable 'green' elements (see Section 3.2).

\section{Private Finance}

For private commercial FIs, the recognition of environmental responsibility has generally come about more recently than for their public counterparts, and as a result, this recognition is still evolving internationally.

A number of commercial banks have publicly declared some form of environmental commitment. It might be argued, however, that it may prove advantageous to develop a set of generally accepted and respected guidelines concerning the conduct of the finance sector towards environmental risks

\footnotetext{
9 OECD (2007). 'Recommendation on Common Approaches on the Environment and Officially Supported Export Credits.' OECD, Paris. http://www.olis.oecd.org/olis/2007doc.nsf/linkto/tad-ecg(2007)9 (accessed on 30 Oct. 2009)
} 
and impacts. In this regard, it is noteworthy that the Basel II Framework, issued by the Basel Commission on Banking Supervision, addresses the issue of environmental risk only with respect to the recommendation that banks "appropriately monitor the risk of environmental liability arising in respect of the collateral, such as the presence of toxic material on a property" (item 510). According to Basel II, the bank must "maintain a continuous monitoring process that is appropriate for the specific exposures (either immediate or contingent) attributable to the collateral to be utilised as a risk mitigant; compliance with loan covenants, environmental restrictions, and other legal requirements should be reviewed on a regular basis" (item 518). ${ }^{10}$

There currently exist a number of guidelines, agreements and mechanisms that aim at introducing global environmental and social responsibility mechanisms that can be endorsed, signed or joined by FIs from different countries. These mechanisms range from basic declarations of intent that are applicable to any FIs, to those that are applicable only to certain types of institutions, or to those that focus only on particular financial instruments or particular aspects of the environment.

An initiative covering all areas of business is the UN Global Compact ${ }^{11}$ which was founded in 2000. The Global Compact comprises ten principles related to human rights, the environment, labour standards and anti-corruption, and is based upon the following documents: the Universal Declaration of Human Rights; the ILO Declaration on Fundamental Principles and Rights at Work; the Rio Declaration on Environment and Development; and the UN Convention Against Corruption. Approximately 6700 business partners from various sectors, including hundreds of FIs, in over 130 countries, have joined the Global Compact initiative as of mid 2009. The ten Global Compact principles aim to incorporate efforts to achieve the UN Millennium Development Goals into mainstream business policy. In 2008 and 2009, the Global Compact Office took the step of delisting hundreds of companies from its list of participants, based on the failure of these companies to report on their progress in implementing the Compact principles, which is a minimum requirement for membership.

By contrast, the Equator Principles (EPs) ${ }^{12}$ are the best example of a set of guidelines focusing on a specific type of business and financial product. The EPs are exclusively applicable to project finance with a total project cost of more than USD 10 million. Launched in 2003 by 10 banks in collaboration with the IFC, the Equator Principles have since been adopted by nearly 70 banks from around the world (as of September 2009). ${ }^{13}$ These banks include, for example, Banco do Brazil, Bank of America, Barclays plc, BNP Paribas, Citigroup Inc., Credit Suisse Group, HSBC Group, HypoVereinsbank, ING Group, JPMorgan Chase, Societe General, the Royal Bank of Scotland, etc. In 2007, USD 52.9 billion of the total amount of USD 74.6 billion, i.e. 71 percent $^{14}$ provided as project finance to emerging markets was subject to the EPs.

The EPs have in general been positively received in both the financial and environmental spheres. The EPs are based upon the IFC Performance Standards and apply the EHS Guidelines (as described above). They are voluntary in nature, and every adopting FI is required to issue a statement proclaiming its endorsement of the Principles, as well as to report on progress in their

\footnotetext{
${ }^{10}$ Basel Committee on Banking Supervision/Bank for International Settlements (2005). 'International Convergence of Capital Measurement and Capital Standards: A Revised Framework'. Basel Committee on Banking Supervision/Bank for International Settlements, Basel. http://www.bis.org/publ/bcbs118.pdf (accessed on 30 Oct. 2009)

${ }^{11}$ www.unglobalcompact.org

12 Equator Principles (2006). "The "Equator Principles": A financial industry benchmark for determining, assessing and managing social and environmental risk in project finance'. www.equator-principles.com

13 Reuters, 8 May 2008. http://www.reuters.com/article/pressRelease/idUS142792+08-May-2008+BW20080508 (accessed on 30 Oct. 2009)

14 Handelsblatt, 16 Jul. 2008. http://www.handelsblatt.com/technologie/nachhaltig_wirtschaften/oekologie-praegtprojektfinanzierung;2012267 (accessed on 30 Oct. 2009)
} 
implementation as a minimum requirement for continued participation. Similarly to the UN Global Compact, failure to communicate progress potentially may result in delisting. The Addenda section of this report includes a first-hand description of the experience of adopting and implementing the EPs, written by Mr. Osamu Odawara, Senior Vice President and Head of the Sustainable Development Department at Mizuho Corporate Bank.

Another remarkable relevant development is the United Nations Environmental Programme Finance Initiative (UNEP FI). This is a network of FIs, numbering more than 170 signatories as of mid 2009 (including for the most part banks and insurance companies), in which dialogue regarding environmental and social issues in the finance sector is nurtured and where best practice can be exchanged and supported by capacity building measures and extensive research.

In terms of the history of the UNEP FI, in 1991 a group of commercial banks joined forces with United Nations Environment Programme (UNEP) to work on incorporating an environmental agenda into the banking industry's operations. In 1992, the UNEP Financial Institutions Initiative was launched, and this was followed three years later by the UNEP Insurance Industry Initiative. These Initiatives were merged into the current UNEP FI in 2003.

Each member of the UNEP FI is required to sign the UNEP FI statement, thereby committing to implement mechanisms to reach a number of broadly-formulated goals that are set out in the statement. These goals focus on sustainable development and the importance of responsible environmental management by FIs. They also commit signatories to openness and transparency regarding their efforts to achieve these objectives. Every member of the UNEP FI is expected to report annually on the progress it has made towards reaching the goals of the Initiative, attend a UNEP FI Annual General Meeting at least once every two years and pay an annual membership fee.

Another set of principles created by the United Nations is the UN Principles for Responsible Investment (UN PRI) ${ }^{15}$ which cover the area of portfolio investments and are applicable to asset managers and other forms of institutional investors. Launched in 2006, the UN PRI were the result of a joint effort by UNEP FI and the UN Global Compact based on an initiative of former UN Secretary-General Kofi Anan. The UN PRI focus on promoting ESG issues in equity and investment funds. Any signatory of the UN PRI commits to making ESG issues a central component of its analysis of potential investments and to incorporating ESG issues into its own operations. As of mid 2009, UN PRI have been signed by over 510 FIs with total assets under management of over USD 18 trillion. An increasing number of institutional asset owners include UN PRI membership as part of their fund manager selection criteria ${ }^{16}$.

UN PRI signatories commit themselves to promote the Principles and to disclose and report any problems and successes with their implementation. As a result, the minimum requirement for remaining a signatory of the UN PRI is participation in the annual PRI Reporting and Assessment survey. In August 2009, for the first time in the history of the Initiative, five FIs were delisted as signatories from the UN PRI for failure to participate in this annual Reporting and Assessment process. ${ }^{17}$

The Coalition for Environmentally Responsible Economies (CERES) ${ }^{18}$, based and primarily focused on North America, was founded in 1989. The ten Ceres Principles expressed the signatories' commitment to engage in environmentally responsible and sustainable business activities. Currently, the CERES Principles have been adopted by over 50 companies, including a

\footnotetext{
${ }^{15}$ www.unpri.org

${ }^{16}$ Responsible Investor, 28 Jul. 2009. http://www.responsible-investor.com/home/article/pri_ejects/

${ }^{17}$ UN PRI media release, 20 Aug. 2009. http://www.unpri.org/files/delisting final.pdf

${ }^{18}$ www.ceres.org
} 
dozen of the Fortune 500. In 2003, during the first Institutional Investor Summit on Climate Risk held at the United Nations, CERES launched the Investor Network on Climate Risk (INCR) ${ }^{19}$ which aims to assess and mitigate the climate risks associated with business governance. From 10 initial members, the INCR has grown to the current number of 70 institutional investors with representation from a broad spectrum of asset managers, investment and pension funds. Under its finest achievements, the Network lists its Climate Action Plan for investors as well as its members' investments into renewable energies to the value of over USD 1.2 billion.

As transparency and reporting of sustainable approaches to financing are particularly important features of any set of principles and guidelines, the Global Reporting Initiative (GRI) ${ }^{20}$ may be regarded as a welcome standardisation of reporting standards on sustainable social, environmental and economic performance for industry. The GRI began as a joint initiative by CERES and UNEP, but it has been an independent entity since 2002. The GRI is applicable to any type of business or institution within any sector. The current third version of the Sustainable Reporting Guidelines (G3) was published by GRI in 2006. The G3 contains a framework for transparent reporting of industry sector-specific indicators. To date, over 1,500 companies have declared their adoption of the G3 guidelines for their sustainability reporting.

In 2006, the UN Global Compact and the GRI entered into a strategic alliance. In concrete terms, this means that the GRI is the tool for reporting on the implementation of the Global Compact principles. The GRI's G3 guidelines also act as the framework for the Global Compact's Communication on Progress.

A country-level example of addressing environmental management issues in the financial sector is the German Verein für Umweltmanagement in Banken, Sparkassen und Versicherungen e.V. $(\mathbf{V f U})^{21}$. The VfU was founded in 1994 with the aim of incorporating environmental management into the operations and activities of German banks and insurance companies. It highlights the opportunities to reduce expenditure through appropriate environmental management and early environmental risk assessment. Increasing the acceptance and awareness of sustainable development in the German business sector and population is a further declared goal of the VfU. The VfU comprises a relatively small membership of 14; however, some of Germany's largest banks and insurance companies such as Allianz, Commerzbank, Deutsche Bank, HypoVereinsbank, UBS and Deutsche Postbank are amongst its members.

A further example of a regional and sector-specific set of guidelines which have evolved from the financial sector, and which are therefore a source of inspiration to environmentally aware FIs, are the Carbon Principles. ${ }^{22}$ These were created in 2007 by six of the largest banks in the USA in close collaboration with a number of advisors from environmental NGOs and electricity generation companies. The Carbon Principles focus on the electric power generation sector and enforce a socalled Enhanced Diligence Process to assess the damage caused by greenhouse gas emissions that might be released by a power plant in cases where the construction of such a plant is to be financed by a Carbon Principles signatory. As well as applying other international sustainable lending standards, the Carbon Principles provide a well-structured framework for project appraisal and for certain loan terms. Carbon Principles signatory banks also commit to educating their clients, regulators and the industry on their Enhanced Diligence Process in order to encourage regulatory and legislative changes consistent with the Principles. In addition, the signatories wish to encourage

\footnotetext{
${ }^{19}$ www.incr.com

20 www.globalreporting.org

21 www.vfu.de

22 www.carbonprinciples.org
} 
investment in renewable energies and energy efficiency measures as well as advanced technologies in conservative energy generation.

The Carbon Disclosure Project (CDP) ${ }^{23}$ represents a group of close to 500 institutional investors (as of mid 2009) that includes some of the world's largest and best-known FIs such as HSBC, JPMorgan Chase, Bank of America, Merrill Lynch, American International Group, etc. Given these investors' increased concern about risks related to climate change, the CDP sends out information requests on their behalf to public and private organisations throughout the world asking them to report their greenhouse gas emissions and relevant management actions and policies. Companies are encouraged to use the Greenhouse Gas Protocol to calculate their specific emissions. All Signatory Investors have access to all company reports sent to the CDP, even if these are not publicly available.

\footnotetext{
${ }^{23}$ www.cdproject.net
} 
[Pure Profit for Russia: Benefits of Responsible Finance]

Table 1. Integration of Voluntary Environmental and Social Responsibility Mechanisms in the Financial Sector of Selected OECD and OECD Candidate Countries (as of September 2009)

\begin{tabular}{|c|c|c|c|c|}
\hline & $\begin{array}{l}\text { Signatories to } \\
\text { Equator } \\
\text { Principles }\end{array}$ & $\begin{array}{l}\text { Participants } \\
\text { in UNEP } \\
\text { FI }\end{array}$ & $\begin{array}{ll}\text { Signatories } & \text { to } \\
\text { UN PRI } & \end{array}$ & $\begin{array}{l}\text { Investor } \\
\text { Signatories of } \\
\text { CDP }\end{array}$ \\
\hline \multicolumn{5}{|c|}{ Selected OECD Countries } \\
\hline Canada & 7 & 12 & 23 & 5 \\
\hline Czech Republic & - & - & - & - \\
\hline France & 3 & 7 & 35 & - \\
\hline Germany & 4 & 15 & 7 & - \\
\hline Hungary & - & - & - & - \\
\hline Italy & 2 & 3 & 5 & - \\
\hline Japan & 3 & 18 & 13 & 2 \\
\hline South Korea & - & 8 & 12 & - \\
\hline Mexico & - & 1 & 1 & - \\
\hline The Netherlands & 6 & 8 & 35 & 5 \\
\hline Poland & - & - & - & - \\
\hline Spain & 4 & 4 & 10 & 1 \\
\hline Turkey & - & 1 & - & - \\
\hline United Kingdom & 6 & 15 & 72 & 12 \\
\hline United States & 5 & 13 & 92 & 9 \\
\hline \multicolumn{5}{|c|}{ Selected OECD Candidate Countries } \\
\hline Brazil & 6 & 3 & 30 & 2 \\
\hline China & 1 & 4 & $3(\mathrm{HK})$ & - \\
\hline India & - & 2 & 1 & - \\
\hline Russia & - & - & - & - \\
\hline South Africa & 3 & 3 & 23 & - \\
\hline
\end{tabular}

Source: Equator Principles signatory list (www.equator-principles.com), UNEP FI signatory list (www.unepfi.org/signatories/index.html?\&no_cache=1 ), UNPRI signatory list (www.unpri.org/signatories ), CDP signatory investor list (https://www.cdproject.net/en-US/Programmes/Pages/Members-List.aspx ). 
Table 2a. Comparative Analysis of Internal Social and Environmental Responsibility Mechanisms of Leading Multilateral FIs

\begin{tabular}{|c|c|c|c|c|c|c|c|}
\hline & Scope & $\begin{array}{l}\text { Screening and } \\
\text { classification of } \\
\text { projects into } \\
\text { Category A, B } \\
\text { and C depending } \\
\text { on their } \\
\text { environmental } \\
\text { impact. Internal } \\
\text { EIA requirement } \\
\text { to the borrower } \\
\text { for all A and } \\
\text { some B projects. }\end{array}$ & $\begin{array}{l}\text { Are there } \\
\text { technical } \\
\text { indicators and } \\
\text { requirements? }\end{array}$ & $\begin{array}{l}\text { How is compliance with the } \\
\text { guidelines monitored? } \\
\text { Independent review? }\end{array}$ & $\begin{array}{l}\text { What } \\
\text { happens in } \\
\text { case of non- } \\
\text { compliance? }\end{array}$ & $\begin{array}{l}\text { Establishme } \\
\text { nt of a CSR } \\
\text { Committee }\end{array}$ & $\begin{array}{l}\text { Establishment } \\
\text { of an } \\
\text { independent } \\
\text { body for } \\
\text { environmenta } \\
\text { I and social } \\
\text { complaints } \\
\text { (Ombudsman } \\
\text { ) }\end{array}$ \\
\hline $\begin{array}{l}\text { International } \\
\text { Finance } \\
\text { Corporation } \\
\text { (IFC) }\end{array}$ & $\begin{array}{l}\text { All projects } \\
\text { financed by the } \\
\text { IFC directly or } \\
\text { through financial } \\
\text { intermediaries }\end{array}$ & Yes & $\begin{array}{l}\text { Yes - } \\
\text { EHS Guidelines }\end{array}$ & $\begin{array}{l}\text {-periodic reports by client on } \\
\text { implementation of Social and } \\
\text { Environmental Action Plan } \\
\text {-projects with severe impacts require } \\
\text { independent monitoring }\end{array}$ & $\begin{array}{l}\text { Efforts are } \\
\text { undertaken to } \\
\text { bring client } \\
\text { back on track; } \\
\text { if client fails } \\
\text { to do so IFC } \\
\text { will decide } \\
\text { remedies on a } \\
\text { case-by-case } \\
\text { basis }\end{array}$ & $\begin{array}{l}\text { Environment } \\
\text { and Social } \\
\text { Development } \\
\text { Department; } \\
\text { Corporate } \\
\text { Governance } \\
\text { Unit }\end{array}$ & $\begin{array}{l}\text { Yes - } \\
\text { Compliance } \\
\text { Advisor } \\
\text { Ombudsman } \\
\text { (CAO) }\end{array}$ \\
\hline $\begin{array}{l}\text { European } \\
\text { Bank of } \\
\text { Reconstruction } \\
\text { and } \\
\text { Development } \\
\text { (EBRD, } \\
\text { Signatory of } \\
\text { UNEP FI) }\end{array}$ & $\begin{array}{l}\text { All projects } \\
\text { financed by the } \\
\text { EBRD directly or } \\
\text { through financial } \\
\text { intermediaries }\end{array}$ & Yes & $\begin{array}{l}\text { Yes - } \\
\text { EBRD uses the } \\
\text { applicable EU } \\
\text { standards and the } \\
\text { World Bank } \\
\text { Group's EHS } \\
\text { Guidelines } \\
\text { where no } \\
\text { equivalent EU } \\
\text { standards exist }\end{array}$ & $\begin{array}{l}\text { - annual report by client on } \\
\text { implementation of Social and } \\
\text { Environmental Action Plan } \\
\text {-Monitoring missions by EBRD } \\
\text { specialists } \\
\text {-periodic third party monitoring, e.g. by } \\
\begin{array}{l}\text { Independent specialists or local } \\
\text { community }\end{array}\end{array}$ & $\begin{array}{l}\text { Efforts are } \\
\text { undertaken to } \\
\text { bring client } \\
\text { back on track; } \\
\text { if client fails } \\
\text { to do so } \\
\text { EBRD will } \\
\text { decide } \\
\text { remedies on a } \\
\text { case-by-case } \\
\text { basis }\end{array}$ & $\begin{array}{l}\text { Environment } \\
\text { and } \\
\text { Sustainability } \\
\text { Department }\end{array}$ & $\begin{array}{l}\text { Yes - } \\
\text { Independent } \\
\text { Resource } \\
\text { Mechanism } \\
\text { (IRM) }\end{array}$ \\
\hline $\begin{array}{l}\text { Asian } \\
\text { Development } \\
\text { Bank (ADB) }\end{array}$ & $\begin{array}{l}\text { All projects } \\
\text { financed by the } \\
\text { ADB directly or } \\
\text { through financial } \\
\text { intermediaries }\end{array}$ & Yes & $\begin{array}{l}\text { Yes - } \\
\text { ADB utilises the } \\
\text { environmental } \\
\text { standards } \\
\text { defined in the } \\
\text { World Bank }\end{array}$ & $\begin{array}{l}\text {-Semi-annual reports by clients on } \\
\text { implementation of Social and } \\
\text { Environmental Action Plan } \\
\text {-annual ADB review missions }\end{array}$ & $\begin{array}{l}\text { Efforts are } \\
\text { undertaken to } \\
\text { bring client } \\
\text { back on track; } \\
\text { if client fails } \\
\text { to do so ADB }\end{array}$ & $\begin{array}{l}\text { Environment } \\
\text { and Social } \\
\text { Safeguard } \\
\text { Division and } \\
\text { Environment } \\
\text { Committee }\end{array}$ & $\begin{array}{l}\text { Yes - } \\
\text { Compliance } \\
\text { Review Panel }\end{array}$ \\
\hline
\end{tabular}


[Pure Profit for Russia: Benefits of Responsible Finance]

\begin{tabular}{|c|c|c|c|c|c|c|c|}
\hline & Scope & $\begin{array}{l}\text { Screening and } \\
\text { classification of } \\
\text { projects into } \\
\text { Category A, B } \\
\text { and C depending } \\
\text { on their } \\
\text { environmental } \\
\text { impact. Internal } \\
\text { EIA requirement } \\
\text { to the borrower } \\
\text { for all A and } \\
\text { some B projects. }\end{array}$ & $\begin{array}{l}\text { Are there } \\
\text { technical } \\
\text { indicators and } \\
\text { requirements? }\end{array}$ & $\begin{array}{l}\text { How is compliance with the } \\
\text { guidelines monitored? } \\
\text { Independent review? }\end{array}$ & $\begin{array}{l}\text { What } \\
\text { happens in } \\
\text { case of non- } \\
\text { compliance? }\end{array}$ & $\begin{array}{l}\text { Establishme } \\
\text { nt of a CSR } \\
\text { Committee }\end{array}$ & $\begin{array}{l}\text { Establishment } \\
\text { of an an } \\
\text { independent } \\
\text { body for } \\
\text { environmenta } \\
\text { I and social } \\
\text { complaints } \\
\text { (Ombudsman } \\
\text { ) }\end{array}$ \\
\hline & & & $\begin{array}{l}\text { Pollution } \\
\text { Prevention and } \\
\text { Abatement } \\
\text { Handbook, but } \\
\text { retains flexibility } \\
\text { to decide on } \\
\text { applicable } \\
\text { standards from } \\
\text { case to case }\end{array}$ & $\begin{array}{l}\text {-in some cases third party monitoring } \\
\text { may implemented to ensure compliance }\end{array}$ & $\begin{array}{l}\text { will decide } \\
\text { remedies on a } \\
\text { case-by-case } \\
\text { basis }\end{array}$ & & \\
\hline
\end{tabular}

Source: WWF analysis based on official texts of the discussed frameworks. 
Table 2b. Comparative Analysis of International Social and Environmental Responsibility Frameworks Adopted by Leading FIs

\begin{tabular}{|c|c|c|c|c|c|c|c|}
\hline & $\begin{array}{l}\text { Who do } \\
\text { these } \\
\text { mechanisms } \\
\text { address? }\end{array}$ & Scope & $\begin{array}{l}\text { Screening } \\
\text { classification } \\
\text { projects of } \\
\text { Category A, B and C } \\
\text { into } \\
\text { environmenting on their } \\
\text { impact. Internal EIA } \\
\text { requirement to the } \\
\text { borrower for all A } \\
\text { and some B projects. }\end{array}$ & $\begin{array}{l}\text { Are there } \\
\text { technical } \\
\text { indicators and } \\
\text { requirements? }\end{array}$ & $\begin{array}{l}\text { How is compliance with } \\
\text { the guidelines } \\
\text { monitored? } \\
\text { Independent review? }\end{array}$ & $\begin{array}{l}\text { Establishment of a } \\
\text { CSR Committee }\end{array}$ & $\begin{array}{l}\text { Establishment of } \\
\text { an independent } \\
\text { body for } \\
\text { environmental } \\
\text { and social } \\
\text { complaints } \\
\text { (Ombudsman) }\end{array}$ \\
\hline $\begin{array}{l}\text { OECD } \\
\text { 'Common } \\
\text { Approaches }\end{array}$ & $\begin{array}{l}\text { Export Credit } \\
\text { Agencies }\end{array}$ & $\begin{array}{l}\text { Officially } \\
\text { supported export } \\
\text { credits with } \\
\text { repayment terms } \\
\text { of } 2 \text { years or } \\
\text { longer }\end{array}$ & Yes & 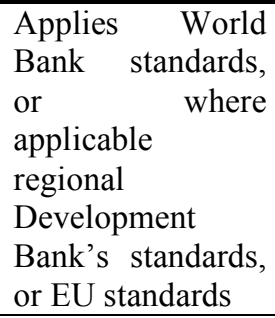 & $\begin{array}{l}\text { ECAs are required to } \\
\text { report annually on } \\
\text { category A and B projects } \\
\text { and on successes and } \\
\text { limitation } \\
\text { implementing of } \\
\text { recommendations }\end{array}$ & $\begin{array}{l}\text { No specific ESG } \\
\text { committee, but the } \\
\text { OECD's Export } \\
\text { Credit Group is } \\
\text { commissioned with } \\
\text { working on the } \\
\text { matter }\end{array}$ & No \\
\hline $\begin{array}{l}\text { Equator } \\
\text { Principles }\end{array}$ & $\begin{array}{l}\text { Banks } \\
\text { engaging in } \\
\text { project } \\
\text { finance }\end{array}$ & $\begin{array}{l}\text { All project } \\
\text { finance credits } \\
\text { issued by the } \\
\text { bank with a } \\
\text { value of more } \\
\text { than USD } 10 \\
\text { million }\end{array}$ & Yes & $\begin{array}{l}\text { Yes } \quad-\text { IFC } \\
\text { Performance } \\
\text { Standards and } \\
\text { EHS Guidelines }\end{array}$ & $\begin{array}{l}\text { - an independent expert is } \\
\text { required to review and } \\
\text { monitor the process of the } \\
\text { project for category A } \\
\text { projects } \\
\text {-the signatory bank also } \\
\text { needs to conduct a } \\
\text { progress and experience } \\
\text { report on the } \\
\text { implementation of the } \\
\text { principles }\end{array}$ & $\begin{array}{l}\text { The Equator Bank } \\
\text { Steering committee } \\
\text { is composed of } \\
\text { representatives from } \\
\text { the signatory banks }\end{array}$ & No \\
\hline UNEP FI & $\begin{array}{l}\text { Financial } \\
\text { institutions }\end{array}$ & $\begin{array}{l}\text { Directed at } \\
\text { signatory's entire } \\
\text { business policy }\end{array}$ & Not specified & $\begin{array}{l}\text { No- } \\
\text { UNEP FI is a } \\
\text { policy- orientated } \\
\text { statement of intent }\end{array}$ & $\begin{array}{l}\text { Policies are aspirational in } \\
\text { nature; every signatory is } \\
\text { requested to issue annual } \\
\text { progress report on the } \\
\text { implementation of } \\
\text { sustainability mechanisms }\end{array}$ & $\begin{array}{l}\text { Yes } \\
\text { UNEP FI Steering } \\
\text { Committee has } \\
\text { representatives from } \\
\text { signatories, working } \\
\text { groups and regional } \\
\text { task force, as well as } \\
\text { UNEP }\end{array}$ & No \\
\hline
\end{tabular}




\begin{tabular}{|c|c|c|c|c|c|c|c|}
\hline & $\begin{array}{l}\text { Who do } \\
\text { these } \\
\text { mechanisms } \\
\text { address? }\end{array}$ & Scope & $\begin{array}{l}\text { Screening } \\
\text { classification and } \\
\text { projects of } \\
\text { Category A, B and C } \\
\text { depending on their } \\
\text { environmental } \\
\text { impact. Internal EIA } \\
\text { requirement to the } \\
\text { borrower for all A } \\
\text { and some B projects. }\end{array}$ & $\begin{array}{l}\text { Are there } \\
\text { technical } \\
\text { indicators and } \\
\text { requirements? }\end{array}$ & $\begin{array}{l}\text { How is compliance with } \\
\text { the guidelines } \\
\text { monitored? } \\
\text { Independent review? }\end{array}$ & $\begin{array}{l}\text { Establishment of a } \\
\text { CSR Committee }\end{array}$ & $\begin{array}{l}\text { Establishment of } \\
\text { an independent } \\
\text { body for } \\
\text { environmental } \\
\text { and social } \\
\text { complaints } \\
\text { (Ombudsman) }\end{array}$ \\
\hline UN PRI & $\begin{array}{l}\text { Institutional } \\
\text { investors, } \\
\text { asset } \\
\text { managers, } \\
\text { pension funds } \\
\text { etc. }\end{array}$ & $\begin{array}{l}\text { Directed at } \\
\text { signatory's entire } \\
\text { business policy }\end{array}$ & Not specified & $\begin{array}{l}\text { No - } \\
\text { UN PRI are } \\
\text { policy- orientated; } \\
\text { implementation as } \\
\text { 'work in progress' }\end{array}$ & $\begin{array}{l}\text { Signatories fill in annual } \\
\text { questionnaire, the } \\
\text { Reporting and } \\
\text { Assessment Framework to } \\
\text { report on progress of } \\
\text { implementing } \\
\text { Principles }\end{array}$ & $\begin{array}{l}13 \text { person board } \\
\text { comprising } \\
\text { representatives of } \\
\text { signatories, UN and } \\
\text { UNEP }\end{array}$ & No \\
\hline $\begin{array}{l}\text { Global } \\
\text { Compact }\end{array}$ & All business & $\begin{array}{l}\text { Directed at } \\
\text { signatory's entire } \\
\text { business policy }\end{array}$ & Not specified & $\begin{array}{l}\text { No - } \\
\text { Global Compact } \\
\text { has } \\
\text { aspirational } \\
\text { principles and } \\
\text { sees itself as a } \\
\text { network for } \\
\text { developing } \\
\text { responsible } \\
\text { corporate } \\
\text { governance }\end{array}$ & $\begin{array}{l}\text { Signatories prepare an } \\
\text { annual report (e.g. } \\
\text { Sustainability Report) } \\
\text { highlighting their progress } \\
\text { on environmental and } \\
\text { social corporate } \\
\text { governance }\end{array}$ & $\begin{array}{l}\text { The Global } \\
\text { Compact Board } \\
\text { consists } \\
\text { representatives from } \\
\text { business, the UN } \\
\text { and civil society in } \\
\text { the form of NGOs } \\
\text { and is chaired by the } \\
\text { UN Secretary- } \\
\text { General }\end{array}$ & No \\
\hline $\begin{array}{l}\text { CERES } \\
\text { Principles }\end{array}$ & All business & $\begin{array}{l}\text { Directed at } \\
\text { signatory's entire } \\
\text { business policy }\end{array}$ & Not specified & $\begin{array}{l}\text { No - } \\
\text { the CERES } \\
\text { Principles are } \\
\text { orientated towards } \\
\text { business } \\
\text { governance and } \\
\text { are a declaration } \\
\text { of intent }\end{array}$ & $\begin{array}{l}\text { Annual sustainability } \\
\text { reports by members }\end{array}$ & $\begin{array}{l}\text { CERES Board of } \\
\text { Directors consists of } \\
\text { representatives of } \\
\text { members (largely } \\
\text { civil society) and } \\
\text { CERES staff }\end{array}$ & No \\
\hline
\end{tabular}

Source: WWF analysis based on official texts of the discussed frameworks. 
Table 3. Comparative Analysis of Social and Environmental Responsibility Policies of Selected National Development Banks

\begin{tabular}{|c|c|c|c|c|c|}
\hline Feature/FI & $\begin{array}{l}\text { China Development Bank } \\
\text { (CDB) }\end{array}$ & KfW Banking Group & $\begin{array}{l}\text { Korea Development Bank } \\
\text { (KDB) }\end{array}$ & $\begin{array}{l}\text { Brazilian Development } \\
\text { Bank (BNDES) }\end{array}$ & $\begin{array}{l}\text { Eurasian Development } \\
\text { Bank }\end{array}$ \\
\hline $\begin{array}{l}\text { Affiliation } \\
\text { with the state }\end{array}$ & $\begin{array}{l}\text { Under the direct leadership of } \\
\text { the State Council }\end{array}$ & $\begin{array}{l}\text { Promotional bank under the } \\
\text { ownership of the Federal } \\
\text { Republic and the Länder } \\
\text { (federal states) }\end{array}$ & State-owned bank & Federal public company & $\begin{array}{l}\text { Operates with the support of } \\
\text { the founding member states - } \\
\text { Russia and Kazakhstan }\end{array}$ \\
\hline $\begin{array}{l}\text { Risk } \\
\text { Management }\end{array}$ & $\begin{array}{l}\text { Actively promotes the } \\
\text { implementation of Basel II } \\
\text { standard and strives to meet } \\
\text { it by the end of } 2010 \text {. }\end{array}$ & $\begin{array}{l}\text { The capital requirement for } \\
\text { operational risks is calculated } \\
\text { using the regulatory standard } \\
\text { approach according to Basel } \\
\text { II. }\end{array}$ & $\begin{array}{l}\text { Basel II Accord was } \\
\text { scheduled to be implemented } \\
\text { by KDB in } 2008 .\end{array}$ & $\begin{array}{l}\text { In place } \\
\text { "New Operational Model", } \\
\text { project AGIR (Funding } \\
\text { Integrate Management) }\end{array}$ & $\begin{array}{l}\text { Uses the basic indicative } \\
\text { approach recommended by } \\
\text { the Basel Committee for } \\
\text { Banking Supervision. }\end{array}$ \\
\hline $\begin{array}{l}\text { Total size of } \\
\text { the lending } \\
\text { portfolio }\end{array}$ & USD 330.7 billion (2007) & EUR 341billion (2007) & USD 40.4 billion (2007) & USD 78.4billion (1H 2008) & 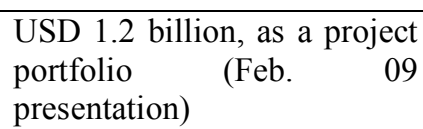 \\
\hline $\begin{array}{l}\text { Corporate } \\
\text { lending into } \\
\text { the } \\
\text { environmental } \\
\text { protection } \\
\text { projects }\end{array}$ & $\begin{array}{l}\text { Total size: USD } 17.5 \text { billion } \\
(2007)\end{array}$ & $\begin{array}{l}\text { The promotion of } \\
\text { environmental and climate } \\
\text { protection is currently at } \\
\text { around } 20 \text { percent of KfW } \\
\text { Bankengruppe's total volume } \\
\text { of commitments. The bank } \\
\text { extends long term/low- } \\
\text { interest financing via KfW } \\
\text { Entwicklungsbank, DEG and } \\
\text { KfW Ipex Bank. }\end{array}$ & Not available & $\begin{array}{l}\text { Lending into } \\
\text { of thedernisation } \\
\text { infrastructure: USD } 10.8 \\
\text { billion } \\
\text { Three } \\
\text { operations: Support to } \\
\text { Environmental Investments, } \\
\text { Support to Energy Efficiency } \\
\text { (PROESCO) and Support to } \\
\text { Carajas Reforestation } \\
\text { (REFLORESTA) }\end{array}$ & $\begin{array}{l}\text { Not available } \\
\text { One of the investment } \\
\text { objectives is aimed at } \\
\text { efficiency enhancement of } \\
\text { natural resources' utilization } \\
\text { and environmental } \\
\text { protection. }\end{array}$ \\
\hline
\end{tabular}


[Pure Profit for Russia: Benefits of Responsible Finance]

\begin{tabular}{|c|c|c|c|c|c|}
\hline $\begin{array}{l}\text { Availability of } \\
\text { the } \\
\text { Sustainability } \\
\text { Report }\end{array}$ & Available since 2007 & $\begin{array}{l}\text { Available since } 2006 \\
\text { Environmental report } \\
\text { released once every three } \\
\text { years, published since } 2000\end{array}$ & $\begin{array}{l}\text { NA } \\
\text { (some mentioning in the } \\
\text { annual report) }\end{array}$ & $\begin{array}{l}\text { Availability of Social Report } \\
\text { (2005 \& 2006) } \\
\text { Availability } \\
\text { Environmental Policy (e.g. } \\
\text { the bank does not provide } \\
\text { financing for projects } \\
\text { contributing to deforestation) }\end{array}$ & $\begin{array}{l}\text { NA } \\
\text { There is a section on social } \\
\text { and environmental } \\
\text { responsibility in the Annual } \\
\text { Report } \\
\text { The activities which are not } \\
\text { eligible for the bank's } \\
\text { financing are thoroughly- } \\
\text { outlined }\end{array}$ \\
\hline $\begin{array}{l}\text { Bank loans: } \\
\text { key } \\
\text { environmental } \\
\text { priority areas }\end{array}$ & $\begin{array}{l}\text { Urban infrastructure, } \\
\text { industrial pollution and waste } \\
\text { treatment, wildlife/natural } \\
\text { forest conservation }\end{array}$ & $\begin{array}{l}\text { Commitments totaling to } \\
\text { EUR } 16.6 \text { billion }(2007)\end{array}$ & $\begin{array}{l}\text { Not available } \\
\text { The bank has been a } \\
\text { traditional provider of } \\
\text { industrial capital, e.g. IT, } \\
\text { biotechnology and } \\
\text { nanotechnology. } \\
\text { Environmental priority areas } \\
\text { have not been identified. }\end{array}$ & $\begin{array}{l}\text { The bank primarily focuses } \\
\text { on financing large-scale } \\
\text { industrial and infrastructure } \\
\text { projects. } \\
\text { Social investments: education } \\
\text { and health, family } \\
\text { agriculture, basic sanitation } \\
\text { and mass transportation. }\end{array}$ & $\begin{array}{l}\text { Not available } \\
\begin{aligned} \text { The bank's priority sectors: } \\
\text { - } \quad \text { Electric power; } \\
\text { - } \quad \text { Hydro-electric } \\
\text { complexes; } \\
\text { - } \quad \text { Transport } \\
\quad \text { infrastructure; } \\
\text { - } \quad \text { High-tech }\end{aligned}\end{array}$ \\
\hline $\begin{array}{l}\text { Commitment } \\
\text { to corporate } \\
\text { social } \\
\text { responsibility }\end{array}$ & $\begin{array}{l}\text { Loans to low-income housing } \\
\text { and education schemes + } \\
\text { micro loans }\end{array}$ & & $\begin{array}{lr}\text { Primarily involved } & \text { in } \\
\text { philanthropic activities } & \end{array}$ & $\begin{array}{l}\text { Availability of Social Report } \\
\text { Association with the } \\
\text { Ombudsman's office }\end{array}$ & $\begin{array}{l}\text { Not available } \\
\text { Indirect, as a consequence of } \\
\text { modernisation / cooperation } \\
\text { objectives }\end{array}$ \\
\hline $\begin{array}{l}\text { Mitigation } \\
\text { measures }\end{array}$ & $\begin{array}{l}\text { Member of the } \text { United } \\
\text { Nations Global Compact } \\
\text { since 20006 }\end{array}$ & $\begin{array}{l}\text { Signatory of the Equator } \\
\text { Principles, plus internal } \\
\text { "Sustainability Guidelines", } \\
\text { plus UN PRI. } \\
\text { EIA as part of loan appraisal } \\
\text { for individual projects } \\
\text { KfW Carbon Fund. }\end{array}$ & $\begin{array}{l}\text { The bank promoted the } \\
\text { establishment of a carbon } \\
\text { fund. } \\
\text { Further measures could be } \\
\text { expected as in February } 09 \\
\text { the government presented its } \\
\text { plans regarding green } \\
\text { growth, e.g. building } \\
\text { nationwide network of } \\
\text { bicycle paths and promotion } \\
\text { of energy-efficient LED } \\
\text { lamps at public facilities. }\end{array}$ & $\begin{array}{l}\text { BNDES Fund for Clean } \\
\text { Development }\end{array}$ & Not available \\
\hline
\end{tabular}

Source: WWF analysis based on the reports on the banks' corporate websites as of February 2009. 


\subsection{Impact of Responsibility Mechanisms on FIs' Performance}

\section{Mark Eckstein and Ivetta Gerasimchuk}

There is a growing body of evidence showing that the integration of environmental, social and governance (ESG) requirements in lending and investment decisions generates business benefits for banks and their clients (Figure 3). ${ }^{24}$ Currently these are most closely linked to a range of risk management and relationship benefits.

\section{Figure 3. The Dynamic Business Case for Responsible Banking in Emerging Markets}

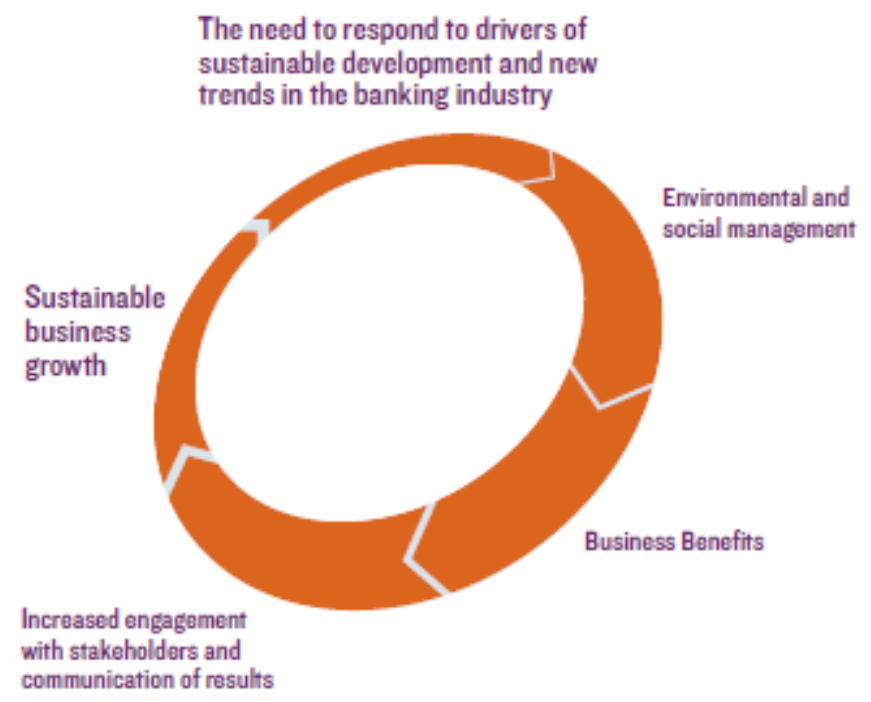

Source: IFC (2007). 'Banking on Sustainability. Financing Environmental and Social Opportunities in Emerging Markets. IFC, Washington.' $\quad$ P. http://www.ifc.org/ifcext/enviro.nsf/AttachmentsByTitle/p_BankingonSustainability/\$FILE/FINAL_IFC Bankin gOnSustainability_web.pdf (accessed on 30 Oct. 2009)

However, despite numerous academic and brokerage studies on the subject, the relationship between financial performance and ESG commitments in the banking sector remains opaque for a number of reasons including the following:

- Sustainability is only one of the factors influencing returns in most financing transactions; other important factors are the quality of overall management and risk management;

- It is difficult to distinguish between different types of CSR (reactive vs. strategic), which have different implications for the FI's core businesses;

- The attribution of financial performance to social and environmental issues is limited by the fact that the latter are not "monetised", or in other words are not incorporated into financial projections (in this regard, financial performance and social or environmental responsibility might be considered as "apples and pears");

- Linked to this, the failure to explicitly cite ESG issues as a factor in the capital allocation of banks (as it is not required by the Basel II accord) means that there is continuing variability in the level of attention and consistency that FIs' place on ESG

\footnotetext{
${ }^{24}$ IFC (2007). 'Banking on Sustainability. Financing Environmental and Social Opportunities in Emerging Markets. IFC, Washington.' http://www.ifc.org/ifcext/enviro.nsf/AttachmentsByTitle/p BankingonSustainability/\$FILE/FINAL IFC Bankin gOnSustainability web.pdf (accessed on 30 Oct. 2009)
} 
risks despite the fact that there is increasing evidence of materiality (e.g. in the case of climate change-related risks);

- Most institutions are at an early stage of incorporating ESG performance in their assessment of investments and have not yet developed tools or processes that rigorously track the effect of positive or negative performance in this regard.

Despite the lack of empirical evidence to prove a direct connection between sustainability and financial performance, a number of leading institutional investors have started integrating sustainability factors into their traditional financial analysis. In particular, in 2007, a Goldman Sachs report found that sustainability leaders outperformed the general stock market by 25 percent over the previous two years and outperformed their same-sector peers by almost 75 percent over the same period. ${ }^{25}$ It can therefore be argued that the strong relationship between such superior financial performance and the environmental and social sustainability of companies is primarily a reflection of common determinants of both (prudent management of the organisation, risks, etc) and a related selection bias rather than of genuine causality. In this light, strong social and environmental performance is increasingly seen by investors and stakeholders as a proxy for effective management and governance of both financial institutions and other businesses.

\section{5. 'Green' Finance in Emerging Markets (except Russia)}

\section{Mark Eckstein, Alistair Schorn and Ivetta Gerasimchuk}

Over the past several years, a number of FIs in emerging markets have made commitments to increased ESG assessment in their operations. These include:

- FIs that receive investment from multilateral / bilateral institutions and are required to develop ESG management capacity and commitments as a condition of investment (including through ownership);

- FIs which have voluntarily committed to ESG targets as a competitiveness tool;

- FIs which have been directed to incorporate ESG targets in their financing by state policies or regulations (this is particularly the case for Chinese FIs).

China. A recent Peoples Bank of China $(\mathrm{PBoC})$ and WWF report ${ }^{26}$ concludes that the majority of Chinese FIs are at an early stage in the implementation of sustainable banking practices, and many have yet to take concrete action. However, a combination of market / investor pressure and state direction seems likely to create conditions that support a consistent and rapid adoption of ESG measures in a swathe of the Chinese financial sector.

Over the past several years, $\mathrm{PBoC}$ has been influencing the evolution of sustainable banking through its monetary, interest rate and credit policies. In 2007, it developed an environmental database of Chinese companies requiring commercial banks to review and weigh each applicant's environmental history before approving credit applications. In the same year, PBoC, along with the Ministry of Environmental Protection of China and the China Banking Regulatory Commission, established a green credit system which aims to restrict the availability of credit to companies that are in violation of environmental laws.

\footnotetext{
${ }^{25}$ Ling, A. et al. (2007). 'Introducing GS SUSTAIN'. N.-Y.: Goldman Sachs Global Investment Research. Note 1.

http://www.unglobalcompact.org/NewsandEvents/event archives/2007 Leaders Summit/S1 GOLDMAN Ling. pdf (accessed on 30 Oct. 2009)

${ }^{26}$ PBoC and WWF (2008). 'Towards Sustainable Development: Reform and Future of China's Banking Industry'. People's Bank of China (PBoC) and the WWF, Beijing. http://www.panda.org/index.cfm?uNewsID=146221 (accessed on 30 Oct. 2009)
} 
These requirements need to be viewed in the context of broader adjustments to China's financial sector, which are aimed at addressing a range of legacy issues (including issues of capital adequacy, better credit and risk management, transparency and non-performing loans). Nevertheless, it is within this context that the ESG agenda is beginning to find a foothold in the Chinese financial sector. In particular, in November 2008, China's Industrial Bank became the first Chinese bank to adopt the Equator Principles.

The 2008/9 turmoil in international financial markets notwithstanding, the PBoC / WWF report also concludes that such factors as international best practice (including the Equator Principles), support from the international community, and the experiences of institutions such as ABN AMRO, HSBC, Citi Group and others, provide valuable "lessons learnt" for the Chinese financial sector. These lessons include the need to:

- focus on key risks and issues (for example climate change, the sustainable use of natural resources including water and forests, and the interaction of social and environmental issues);

- develop capacity and tools within the sector (and specifically within individual institutions) that allow for more sustainable investment practices to be delivered in a costeffective, efficient and timely manner;

- demonstrate the impact of investment decisions and develop credible and meaningful mechanisms for disclosing information to a range of interested stakeholders.

The timing and emphasis that $\mathrm{PBoC}$ and the Chinese financial sector are placing on environmental requirements (e.g. 'green' credit and security regulations, etc) form an important precursor and framework for more sustainable banking practices. The challenge in this regard will be to ensure:

- swift, consistent and cost effective integration of these requirements across a broad range of FIs and financial products;

- the existence of appropriate tools and guidance measures for banks and other FIs to use in the implementation of sustainable investment practices;

- the building of national capacity to service the needs of sustainable banking (including specifically consultants, training institutions, and engineering and legal firms).

China's model offers valuable insights into the way in which some other countries might tackle ESG requirements. State and market dimensions of this model have the potential to provide mutual support and guidance in key areas of environmental concern (including climate change, water and air pollution, and natural resource use and exploitation).

Brazil. With contrast to China, the adoption of environmental and social requirements in the financial sector in Brazil is not so significantly underpinned by state regulations. Over the past several years, several private FIs have adopted the Equator Principles, including Banco Bradesco, Banco do Brazil, Intesa Sanpaolo, Itau Unibanco, and Banco Real (owned by Spain's Banco Santander). Within these institutions, there is a significant capacity emerging to manage environmental and social issues in lending and investments. The motivation for this proactive positioning appears to relate to factors such as:

- The existence of forward-thinking by banks with exposure in large infrastructure and soft commodities sectors which are environmentally and socially sensitive;

- Large amounts of foreign direct investment and the requirement for Brazilian banks that syndicate with international banks to have a level playing field regarding environmental and social requirements

- Encouragement on the part of the Brazilian Stock Exchange (Bovespa) for Brazilian companies and FIs to report and disclose their environmental and social performance (thereby creating the opportunity for open debate in this area); 
- A vibrant and engaged NGO sector, which has directed significant focus towards the finance sector.

Brazilian media estimated that at least BRL 17 billion (USD 8.7 billion) of project finance lending by Brazilian banks was tied to Equator Principles conditions in 2007. ${ }^{27}$ Nationwide, large industrial and infrastructure projects (including thermal and hydro power generation) and agribusiness have become increasingly conditioned to social and environmental risk assessments. Brazilian investors and asset managers also actively participate in peer sustainability networks such as the UN Principles for Responsible Investment (30 Brazilian participants as of September 2009) and the Carbon Disclosure Project (2 Brazilian signatory investors).

South Africa. In South Africa, the banking sector is dominated by four major commercial and retail banks: ABSA, First National Bank, Nedbank and Standard Bank. A number of smaller banks operate in certain geographical and cultural niche markets, and several other institutions are focused primarily on investment banking.

Given the political history of South Africa and the huge backlog of social needs to be addressed in the country, it is no surprise that the primary focus of corporate responsibility activities has been in the social rather than the environmental sphere. At the same time, however, the increasingly urgent issue of climate change has become a particular area of focus for the South African government, and as a result, the country's financial industry has markedly increased its level of consideration of this issue. As a severely water-stressed region, Southern Africa has been identified as one of the areas most at risk from the negative impacts of climate change.

As the awareness of environmental concerns, and in particular, of the financial risks associated with environmental degradation, has grown, South African banks have increasingly begun to incorporate ESG issues into their own operations and financing practices. Amongst the four major players, Nedbank has established itself as the leader in terms of environmental responsibility having been the first, and, for a number of years, the only, South African bank to have adopted the Equator Principles.

In February 2009, Standard Bank of South Africa became the second of the country's banks to adopt the Equator Principles in their project financing activities. Standard Bank is the largest bank in South Africa in terms of assets and earnings ${ }^{28}$ and has a significant presence in Africa (trading primarily as Stanbic Bank). Standard Bank is also actively expanding its international presence beyond the African continent, and, during 2009 acquired a 33 percent stake in Troika Dialog, one of Russia's largest investment banks. In July 2009, South Africa's FirstRand Bank also adopted the Equator Principles. South African FIs also participate in the UNEP FI (3 institutions) and UN Principles for Responsible Investment (23 institutions).

\subsection{Future Prospects and Principal Challenges for Responsible Finance Worldwide}

\section{Mark Eckstein and Ivetta Gerasimchuk}

From being an exotic addition to risk management toolkits in the 1990s, environmental and social standards have over the past decade become a mainstream concern for financial institutions in developed countries, and furthermore exhibit an ever-increasing importance in

\footnotetext{
${ }^{27}$ O Estado de S. Paulo, 23 Jul. 2008. http://www.equator-principles.com/brasil_vialli.shtml (accessed on 30 Oct. 2009)

${ }^{28}$ Standard Bank fact sheet: http://www.standardbank.co.za/SB FILES/Investor/SBfactsheet.pdf (accessed on 30 Oct. 2009)
} 
emerging markets such as China, Brazil and South Africa. The impact of sustainability benchmarks across a range of financial products and services is becoming increasingly apparent - from project and export finance to corporate loans, private equity and institutional investments. As an example, the US Private Equity Council, an influential mainstream association of the private equity industry, published new guidelines on ESG issues in February 2009. ${ }^{29}$ A question that remains to be answered, however, concerns the manner in which these challenges are likely to play out as the global financial sector emerges from the 2008/9 economic and liquidity crisis?

Increased government regulations at national and international level will doubtless play a role in driving the sustainability agenda in a post-crisis world. The credit crunch has prompted national governments and international governmental organisations to strengthen regulation and capital adequacy requirements, which is likely to create a situation of increased risk aversion (or at the very least increased risk awareness) across the financial sector. At the same time, climate change regulations and carbon emissions restrictions are likely to be another significant driver in the integration of environmental considerations into the financial decision-making.

Much will also depend on collective action and a more mature approach to ESG issues within the financial sector in general. Due to the 2008/9 financial crisis and the resultant increases in public and government scrutiny of the financial sector worldwide, many financial institutions are in the process of redesigning and improving their risk management tools and approaches. By widening the scope of risk management to include ESG issues, sustainability can be a major contributor to a more resilient and responsible global financial system. As mentioned in Section 1.4, however, the linkages between ESG and financial performance remain relatively opaque, which implies that the process of determining the 'materiality' of risks will no doubt continue to evolve, and that this 'materiality' will become increasingly evident in certain industries, including the following:

- Industries with a large carbon footprint (including oil and gas, mining, cement, pulp and paper), which are likely to be affected by carbon emission regulations. While the precise scope of such regulations remains uncertain in the run-up to the negotiation of an international post-Kyoto climate agreement (to come into effect from 2012), it seems highly likely that increasingly stringent controls will be placed on companies with large carbon footprints. Such controls will of course hold significant implications for FIs who invest in these sectors, and these implications will become more apparent over time;

- Industries with a particular need for renewable natural resources (such as forestry, agribusiness and fisheries), in which increasing resource scarcity will require increasingly costly and complex sourcing arrangements - thereby creating additional and less predictable operating costs and revenue flows. In this regard, the implications of increasing water scarcity and competition between different industry sectors and human needs will be particularly important;

- Industries that depend on export markets (particularly in the EU), in which emerging consumer preferences, as well as the possibility of carbon- and other resource-related border tax adjustments, will require that industries demonstrate increasingly high levels of ESG performance.

\footnotetext{
${ }^{29}$ Private Equity Council media release. 10 Feb. 2009. http://www.privateequitycouncil.org/pressreleases/2009/02/10/private-equity-council-members-adopt-guidelines-for-responsible-investment (accessed on 30 Oct. 2009)
} 
As FIs' understanding of the linkage between ESG performance and the 'materiality' of investment risks and opportunities evolves, it is certain to affect the means by which these FIs price loans, undertake due diligence and assess investment returns. Since project finance is the area in which the methodology of evaluating and mitigating risks (including environmental and social ones) is generally most advanced, it would appear that this area of finance can serve as a significant source of expertise and inspiration for a revised post-crisis financial system. However, the extrapolation of such risk evaluation and mitigation methodologies into other areas of finance will require the development of new tools and approaches, given different degrees of leverage and varying attribution of impacts to specific financial products.

At present, various responsibility standards apply only to a limited (though growing) number of capital market segments, with each set of guidelines restricted to a single type of financing: for example, project finance (Equator Principles), export finance (OECD 'Common Approaches'), institutional investment and asset management (UN PRI), financing electricity generation projects (Carbon Principles), etc. Current trends would appear to indicate the possibility that these sustainability standards will in the future converge, since harmonisation brings down transaction costs and complexities, and creates simpler and more common requirements for clients. For example, the Equator Principles Financial Institutions and export credit agencies of the OECD countries are increasingly aligning environmental appraisal process and requirements.

In spite of these encouraging developments, however, environmental NGOs continue to argue that the most important step in increasing the level of ESG responsibility within the financial sector lies in the development and integration of benchmarks similar to those of the IFC Performance Standards for initial public offerings, Eurobonds and corporate loans as the primary sources of funding for companies engaged in environment-intensive industries. Such benchmarks should interrogate the activities of these companies seeking finance in an overall sense, in order to determine the social and environmental risks associated with their operation as a whole. Although this is a far-reaching goal, some developments in this direction are already underway.

In particular, in response to a growing demand by investors and other stakeholders in this regard, the past several years have seen the development of a number of tools and measures to assess companies from the environmental and social soundness perspective. Specifically, ratings with a sustainability focus such as the Dow Jones Sustainability Index, FTSE4Good, Global 100 and a number of others are sure to increase in importance. Companies as well as banks will have to comply with the requirements of rating institutions, while the significance of environmental and social reporting (for example in the shape of the GRI, Carbon Disclosure Project, etc) will also continue to grow.

Although the environmental and social benchmarks under discussion are voluntary by nature, it is in the best interests of the society and the environment that their implementation takes place in accordance with the principles they state, which is hardly achievable in practice without the existence of sound compliance and grievance mechanisms such as those administered by the Ombudsman's Office of the IFC. At present, however, the majority of FIs peer networks such as the UN PRI and the Equator Principles lack such enforcement bodies and rely primarily on delisting as the ultimate measure of punishment for non-compliance. This accountability challenge remains a constant subject of criticism of such peer networks of FIs on the part of NGOs and other stakeholders.

Importantly, environmental and social issues are for FIs synonymous not only with risks, but also with significant business opportunities. Leading FIs are increasingly attempting to differentiate themselves from competition by delivering innovative products and deals that 
take advantage of sustainability opportunities. The business opportunity aspect of sustainability is gaining momentum, particularly with regard to issues of carbon and climate change, for example, through the funding of Clean Development Mechanism projects under the Kyoto Protocol. According to World Bank estimates, the global carbon market has been one of the few that experienced growth in spite of the global financial crisis: turnover in this market doubled in 2008 to an estimated USD 126 billion (Table 4).

Table 4. Carbon Markets at a Glance. Volumes and Values in 2007 - 2008.

\begin{tabular}{|c|c|c|c|c|}
\hline & \multicolumn{2}{|c|}{2007} & \multicolumn{2}{|c|}{2008} \\
\hline & $\begin{array}{l}\text { Volume, } \\
\text { million tons } \\
\mathrm{CO} 2 \\
\text { equivalent }\end{array}$ & $\begin{array}{l}\text { Value, } \\
\text { USD } \\
\text { million }\end{array}$ & $\begin{array}{l}\text { Volume, } \\
\text { million } \\
\text { tons CO2 } \\
\text { equivalent }\end{array}$ & $\begin{array}{l}\text { Value, } \\
\text { USD } \\
\text { million }\end{array}$ \\
\hline \multicolumn{5}{|c|}{ Project-Based Transactions } \\
\hline $\begin{array}{l}\text { Primary Clean Development Mechanism } \\
\text { (Kyoto Protocol) }\end{array}$ & 522 & 7,433 & 389 & 6,519 \\
\hline Joint Implementation (Kyoto Protocol) & 41 & 499 & 20 & 294 \\
\hline Voluntary market & 43 & 263 & 54 & 397 \\
\hline Sub total & 636 & 8,195 & 463 & 7,210 \\
\hline \multicolumn{5}{|c|}{ Secondary Clean Development Mechanism (Kyoto Protocol) } \\
\hline Sub total & 240 & 5,451 & 1,072 & 26,277 \\
\hline \multicolumn{5}{|c|}{ Allowances Markets } \\
\hline European Trading System (EU) & 2,060 & 49,065 & 3,093 & 91,910 \\
\hline New South Wales (Australia) & 25 & 224 & 31 & 183 \\
\hline Chicago Climate Exchange (USA) & 23 & 72 & 69 & 309 \\
\hline Regional Greenhouse Gas Initiative (USA) & NA & NA & 65 & 246 \\
\hline Assigned Amount Units (Kyoto Protocol) & NA & NA & 18 & 211 \\
\hline Sub total & 2,108 & 49,361 & 3,276 & 92,859 \\
\hline TOTAL & 2,984 & 63,007 & 4,811 & 126,345 \\
\hline
\end{tabular}




\section{CHAPTER 2. An Overview of the Russian Financial Sector}

\subsection{Introduction to the Russian Financial Sector}

Kevin Smith, Kamila Ilyumzhinova and Georg Kraft

The financial sector in Russia is currently in a nascent phase and has yet to reach a stage of maturity seen in other countries. This maturity is typically marked by, firstly, high degrees of capitalisation of the financial markets, and, secondly, consolidation within the financial industry, resulting in emergence of five to ten key FIs.

As far as the undercapitalisation is concerned, in 2007, total bank assets in Russia stood at 68 percent of GDP, substantially lower than in other emerging markets such as Brazil, India and China. ${ }^{30}$ This insufficient level of banking penetration results primarily from a low national savings rate, considerable outflows of capital and a lack of appropriate risk management practices. Russian banks are also highly vulnerable to panic-driven periods of illiquidity, as occurred during the major 1998 financial crisis and the 'mini'-crisis of 2004.

In recent years, a trend of consolidation in the Russian financial sector has begun to emerge, as evidenced by the reduction in the number of licensed credit institutions from 1,329 in January 2004 to 1,108 in January 2009, primarily as a result of license revocation and of mergers and acquisitions. As of January 2009, Russia's top five banks controlled approximately 46.2 percent of total banking assets in the country (compared with 42.3 percent in January 2008), while the 200 largest banks accounted for 93.9 percent of the total industry assets. Further consolidation might be expected in the light of the 2008/9 financial crisis, which has highlighted the existence of severe liquidity shortages for FIs, both globally and within Russia.

In terms of sourcing capital, both industrial companies and banks in Russia are heavily dependent on foreign creditors and investors. Consequently, Russia's economy has been affected by the 2008/9 economic downturn to a greater extent than countries with more selfsufficient financial systems, such as China.

\section{Regulation of the Russian Financial Sector}

The principal regulatory body in the Russian banking system is the Central Bank of the Russian Federation (also officially called Bank of Russia, CBR). The CBR's duties and powers are articulated in Federal Law No. 86-FZ of 10 July 2002 in accordance with Articles 71 and 75 of the Constitution of the Russian Federation. ${ }^{31}$

In terms of this legislation, the Bank of Russia:

- is independent from other state bodies in its duty to secure the Rouble's stability;

- has the power to issue banking licenses to credit institutions and to revoke and suspend them;

- $\quad$ sets rules regarding the practice of conducting banking operations;

- sets rules regarding accounting and reporting for banks;

- sets principles regarding relationship between banks, customers and the state;

- is entrusted with the supervision of Russian banks;

- is the last resort lender for troubled credit institutions and leads the organisation process for the refinancing of such institutions.

\footnotetext{
${ }^{30}$ Robinson, M. (2008). 'International Banking. A Unique Opportunity for Russia'. Presentation given to the Graduate School of Management, St. Petersburg, 10 Apr. 2008.

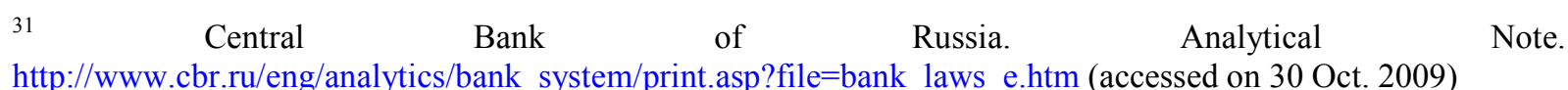


CBR is in charge of implementing the Basel II Accord in Russia, which, so far, has been delayed for a number of reasons. In 2008-2009, CBR was primarily occupied with performing the first and most important of the abovementioned functions because of the significant depreciation of the Rouble against USD and EUR during the financial crisis.

The CBR classification of risks of the Russian financial sector, which is followed by the Russian banks in their business practices, does not include environmental and social risks. Therefore Russian banks do not monitor ESG issues consistently, incorporating them only in very few sporadic cases in such risk categories recognised by CBR as default risk, operating risk, legal risk, risk of reputational losses, and strategic risk.

Further regulation of the financial sector is provided by the Federal Financial Markets Service (FFSM) which is mainly entrusted with the supervision and regulation of financial markets. The FFSM also issues licenses for trading in securities. ${ }^{32}$

Insurance companies are subject to regulation by the Federal Insurance Supervision Service (FISS), while investment funds and non-state pension funds are also regulated by, and are required to be registered with the FFSM.

Further legislation related to risks in the Russian financial sector includes Federal Law No. 62FZ dated 28 May 2001, the Anti-money Laundering Law and Federal Law No. 177-FZ dated 23 December 2003, an act "On Insurance of Household Deposits with Russian Banks", which makes it mandatory for Russian banks to participate in the deposit insurance system thereby reducing risks for customers in case of banks' financial failure or loss of their banking license. $^{33}$

\section{Classification of Russian FIs}

For the purpose of this study, the authors have attempted to classify all FIs operating within Russia into the following categories. They have also attempted to identify potential key drivers for the integration of social and environmental responsibility within each of these categories. Thus far, Russian FIs have tended to take a reactive rather than a strategic approach to $\mathrm{CSR}^{34}$.

\section{Financial Majors: State-Owned Banks}

Six financial institutions can be classified as having a state ownership structure, namely Vnesheconombank (VEB), VTB, Sberbank, Eurasian Development Bank, Russian Agricultural Bank and Gazprombank. Sberbank is by far the largest bank in Russia. The CBR is Sberbank's majority shareholder, controlling 58 percent of the share capital, while a further 20 percent of shares are foreign-owned. ${ }^{35}$

A relatively recent development in the Russian banking industry involves the growing role of VEB, which was transformed into the "Bank for Development and Foreign Economic Affairs" by Federal Law 82-FZ of 17 May 2007. Under this Law, VEB holds the following key characteristics:

\footnotetext{
Status of a "State Corporation";

32 www.fcsm.ru

33 Central Bank of Russia. Analytical Note. http://www.cbr.ru/eng/analytics/bank_system/print.asp?file=bank_laws_e.htm (accessed on 30 Oct. 2009)

34 Polishchuk, L. (2009). 'Corporate Social Responsibility vs. Government Regulation: Institutional Analysis with an Application to Russia.' Higher School of Economics Working Paper. Moscow. http://www.hse.ru/data/393/364/1237/CSR_paper_revised.PDF (accessed on 30 Oct. 2009)

${ }^{35}$ Standard \& Poor's (2007). 'Bank Industry Risk Analysis: Russian Banks Continue To Improve, But Still Burdened By Structural Vulnerabilities'. Standard \& Poors, Moscow.
} 
- $\quad$ Equity is fully owned by the state;

- Developmental functions as a major area of specialization;

- $\quad$ A full range of project and export finance services ${ }^{36}$;

- $\quad$ Acts as an agent of the Government of the Russian Federation, and is authorised to service Russia's sovereign foreign debt and centralise foreign economic operations, manage state external financial assets, and settle Russian borrowers' bad debts towards the federal budget.

Since the beginning of the liquidity crunch, VEB has played the principal role in the government's anti-crisis agenda; the bank was appointed as the key facilitator of the state aid package, aimed at assisting Russian companies and FIs with debt repayment and refinancing. In October 2008, for example, VEB provided an initial USD 8 billion loan to companies operating in the following key industries - energy, metals, construction, transport and communications. Other rescue measures implemented by VEB include its support to heavily indebted FIs, such as its purchase of Svyaz Bank for a symbolic sum of 5,000 Roubles (less than USD 200) and its settlement of all of the debts of this bank.

State-owned VEB and VTB banks are the most active amongst Russian banks in terms of expanding their activities abroad, including, among other channels, through project finance in developing countries that can potentially be subject to the Equator Principles and OECD 'Common Approaches'. For example, throughout 2007, VEB signed a number of agreements aimed at bolstering cooperation between Russian and foreign companies in the area of Russian goods, services and technology exports. These agreements include one with Russia's LLC "Managing Company" Gas Group and the Ural India Ltd. company to create a Russian-Indian joint venture for the purpose of industrial assembly of the "Ural" brand of trucks in the Indian state of West Bengal, as well as another with a Russian company, OJSC Holding Company "Technochim-Holding" and an Indian company, Saraf Agencies Private Ltd., regarding creation of a joint Russian-Indian chemical-metallurgical complex in India to produce titanium dioxide and other titanium products.

As Russian banks integrate into the global financial community via international expansion, it seems likely that the adoption of international sustainability mechanisms will become increasingly important and appropriate for these institutions. It further appears that over the past two years, Russian state-owned banks have begun considering the incorporation of social, environmental and climate change-related factors into their decision-making precisely because of the expansion of their international activities. For example, during 2009, Sberbank was authorised by the national government to implement the Kyoto protocol mechanisms for emissions trading in Russia.

\section{Medium-Sized Players: Private Banks}

In comparison with state-controlled banks, private FIs account for a far lower percentage of Russia's total banking assets; for example, the largest private commercial bank, Alfa Bank, constitutes only approximately 3 percent of these assets. Even before the liquidity crisis, Russia's private banks were in a far less competitive position than the large state-controlled banks that generally enjoy better access to international capital markets, as well as to the various stimulus packages distributed by the Russian government at a lower cost and for a longer term that international financing. Nevertheless, banks such as the Bank of Saint Petersburg, Alfa Bank, NOMOS Bank and several others occasionally tapped the international

\footnotetext{
${ }^{36}$ It is worth noting that, seeking to guarantee support for Russian exporters, VEB applies a wide spectrum of instruments: sureties, stand-by letters of credit, bank guarantees of various types, inclusive of advance payment guarantees, tender guarantees and performance bonds.
} 
Eurobond and syndicated loans markets prior to the beginning of the 2008/9 financial crisis, and these particular issuers were relatively well-known to international investors.

Despite the fact that, as of September 2009, none of the Russian FIs (either state-owned or private) have joined any of the internationally recognised mechanisms of social and environmental responsibility, it is noteworthy that prior to the financial crisis, private banks generally exhibited a far greater commitment to CSR activities than their state-controlled counterparts. For example, according to the database of the Russian Union of Industrialists and Entrepreneurs, as of August 2008, the eight Russian FIs that had ever produced a CSR report were MDM-Bank, URSA-Bank, Uralsib, Alfa Bank, 'Solidarnost' Bank, FIA Bank, AFK 'Sistema' and the Russian subsidiary of Unicreditbank, all of which are private banks.

It would appear that this particular category of Russian FIs might be motivated to utilise the aspect of environmental and social responsibility as a public relations tool in order to enhance their reputations and thereby improve their access to international capital markets. This is particularly the case in the highly competitive "differentiate or die" post-crisis scenario in which issuers with no sovereign support are competing with other private banking institutions from all over the world, and especially from other BRICS.

\section{Financial Intermediaries: Regional Private Banks}

Two multilateral banks, namely the European Bank for Reconstruction and Development (EBRD) and the International Finance Corporation (IFC), have identified the stability of the Russian financial sector as a key strategic priority in terms of their activities in the country. In line with this strategic objective, both these institutions have directed significant attention towards Russian regional banks to which they have provided significant financing over the past several years in the form of both loans and equity participation. This category of Russian FIs includes relatively small banks such as Center-Invest Bank, Vostochny Express Bank and Bank Kedr, all of which have been compelled to follow either EBRD or IFC Performance Standards in their dealings with these multilateral banks.

\section{Banks Integrated into Financial Industrial Groups}

A widespread phenomenon in the Russian banking landscape is the existence of so-called Financial and Industrial Groups. These groups are generally large conglomerates consisting of at least one major industrial enterprise and one bank which are closely associated in a number of ways, one of which is through providing financial services to employees (processing of employees' salaries and depository accounts, etc). Examples include such structures as the Moscow Bank for Reconstruction and Development and its association with the Sistema Group and Transcreditbank and Russian Railways. The primary motivations for any actions on the part of these FIs are likely to arise from the interests of their parent company or the associated industrial enterprise. As a result, it might prove particularly difficult to motivate such institutions to adopt ESG principles and practices.

\section{Russian Subsidiaries of the Foreign FIs}

Over the past several years, foreign FIs have been active in entering the Russian banking arena through the acquisition of Russian FIs. Examples include Barclays' acquisition of Expobank, Societe Generale's purchase of a stake in DeltaCredit, and Standard Bank's acquisition of a stake in the Troika Dialogue investment bank. Furthermore, foreign banks such as Raiffeisen, Unicredit and Societe Generale have established very competitive positions in the retail segment of the banking sector in a relatively short space of time.

In many instances, foreign FIs operating in Russia are already signatories of the Equator Principles, for example HSBC, Royal Bank of Scotland, Barclays, etc. In spite of this 
situation, however, it would appear that a "trickle-down" effect with regard to social and environmental issues and general CSR commitment has not taken place in the majority of Russian subsidiaries of these international FIs. Meanwhile, these subsidiaries can be a priority group for further dialogue regarding the promotion of sustainable banking practices in Russia.

\subsection{Russia's Reliance on Foreign and Domestic Finance}

Kamila Ilyumzhinova

In the period $2000-2008$, the impressive growth in Russia's corporate sector has been fuelled primarily by international capital markets, which have been continuously tapped by Russian financial institutional borrowers. According to the official reports by the Central Bank of Russia, Russia's total (both public and private) external debt amounted to USD 483.5 billion as of end of December 2008 (Table 5). ${ }^{37}$ This represents a significant leverage level (101 percent given the Russian Central Bank's reserves at USD 478.8 billion), but is lower in relevant terms than in many other emerging markets such as Turkey (243 percent in July 2008) or Brazil (109 percent in October 2008). ${ }^{38}$ It is however noteworthy that Russia's foreign reserve position deteriorated markedly as a result of the 2008/9 financial crisis.

Table 5. External Debt of the Russian Federation in $2006-2008$

\begin{tabular}{l|r|r|r}
\hline \multicolumn{1}{c|}{ USD billion } & Dec.06 & Dec.07 & Dec.08 \\
\hline Total Gross External Debt of the Russian Federation & 313.2 & 471.0 & 483.5 \\
\hline Public Sector External Debt (Total) & 137.1 & 190.8 & 161.8 \\
\hline General Government & 44.7 & 37.4 & 29.5 \\
\hline Monetary Authorities & 3.9 & 9.0 & 3.3 \\
\hline Banks & 41.4 & 65.5 & 61.7 \\
\hline Other Sectors & 47.1 & 78.9 & 78.2 \\
\hline Private Sector External Debt (Total) & 176.1 & 280.2 & 332.0 \\
\hline $\begin{array}{l}\text { Banks } \\
\text { (excluding debt liabilities to direct investors) }\end{array}$ & 59.4 & 96.9 & 102.9 \\
\hline $\begin{array}{l}\text { Other Sectors } \\
\text { (excluding debt liabilities to direct investors) }\end{array}$ & 95.2 & 156.4 & 186.0 \\
\hline $\begin{array}{l}\text { Banks and other sectors - debt liabilities to direct investors } \\
\text { (explian }\end{array}$ & 21.5 & 26.9 & 32.7
\end{tabular}

Source: Central Bank of Russia. External Debt of the Russian Federation (Detailed Analytical Presentation of 23 July 2009). http://www.cbr.ru/eng/statistics/print.aspx?file=credit statistics/debtnon_an_08_e.htm\&pid $=$ Svs\&sid=VdRF_nr_ap (accessed on 30 Oct. 2009)

Note: Public Sector External Debt covers liabilities of the General Government, Monetary Authorities, and those entities in the banking and other sectors that are public corporations, i.e. non-financial or financial corporations which are subject to control by government and monetary authorities. Control is established (directly or indirectly) through ownership of more than half of the voting shares or otherwise controlling more than half of the shareholder voting power. Indebtedness of any domestic institutional unit not meeting the definition of Public Sector External Debt is to be classified as Private Sector External Debt.

Meanwhile, official statistics represent the external debt data only at the point of foreign FIs providing loans to Russian entities, while a considerable proportion of the external financing raised by Russian FIs is further channeled into the corporate sector. Therefore the actual

37 Central Bank of Russia. External Debt of the Russian Federation (Detailed Analytical Presentation of 23 July 2009). http://www.cbr.ru/eng/statistics/print.aspx?file=credit_statistics/debt-

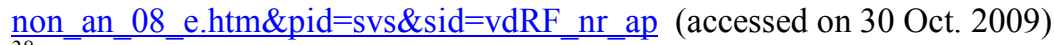

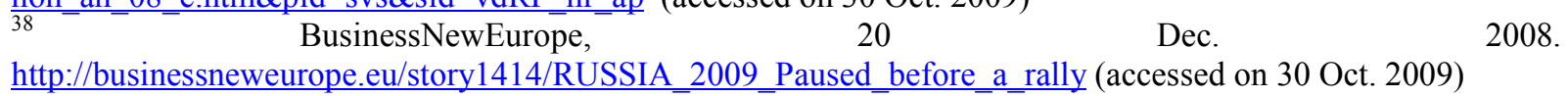


accumulated external debt of the Russian corporate sector is higher and was estimated by Uralsib as being USD 440 billion as of 30 October $2008^{39}$ (Table 6).

Table 6. Funding Sources of the Accumulated Debt of Russia's Corporate Sector as of 30 October 2008

\begin{tabular}{l|l}
\hline Internal sources & 480 \\
\hline Individual deposits & 230 \\
\hline $\begin{array}{l}\text { Remaining balance in the individual and } \\
\text { corporate accounts }\end{array}$ & 250 \\
\hline External sources & 440 \\
\hline Eurobonds & 116 \\
\hline Syndicated loans & 133 \\
\hline Non-public External Debt & 191
\end{tabular}

Sources: Uralsib / Уралсиб (2008). 'Capital Markets' Prospects. Credit Crisis is Changing the Game Rules. Перспективы рынков капитала. Кредитный кризис меняет правила игры.' Uralsib, Debt Capital Market Research Department. Presentation at the $5^{\text {th }}$ Federal Investment Forum, Moscow, 18 Nov. 2008. http://www.fif.rcb.ru/2008/prezentation/ginsbyrg.ppt (accessed on 30 Oct. 2009)

Uralsib also evaluated the overall structure of the Russian corporate sector's accumulated debt, according to industry segment (Figure 4).

The sources of funding of the Russian corporate sector are in general highly concentrated, with the top 30 lenders providing approximately $70-80$ percent of the total value of loans between January 2006 and July 2009 (Table 7). The overwhelming majority of these loans fall into the category of syndicated loans, while the country's project finance segment is relatively small and amounted to USD 6.78 billion between 1 January 2007 and 21 December 2008 (Table 8). This implies that even if the Equator Principles are applied to all project finance activities in Russia, provided by both domestic and foreign FIs, this will have a minimal impact in resolving the CSR challenges that exist in the Russian financial sector.

Western capital markets have traditionally been the major provider of loans to Russian borrowers. However, in the light of the global credit crunch in 2008 - 2009, Russian borrowers have begun shifting their attention from the crisis-stricken US and European FIs to Asian lenders, especially China Development Bank, Bank of Tokyo-Mitsubishi UFJ, Mizuho Corporate Bank and Sumitomo Mitsui Banking Corporation.

The liquidity crisis has also somewhat disrupted the dependence of Russian corporate borrowers on foreign capital, since access to international debt and equity markets has become extremely limited for many private borrowers, leaving only a small window of opportunity for some semi-sovereign entities. As a result, the role of the six largest state-owned Russian banks (VEB, Sberbank, VTB, Gazprombank, Russian Agricultural Bank and Eurasian Development Bank) as loan providers for the Russian real economy has become even greater. According to a survey conducted by the national NGO "Business Russia" 40 , the global liquidity crisis has increased the loan interest rates for Russian SME borrowers to 22.5 percent, thereby significantly reducing access to credit resources for many of these borrowers. For example, in mid 2009 an average interest rate of 10-12 percent was accessible only for approximately 2 percent of all companies, compared to the pre-crisis level of 21 percent of companies.

\footnotetext{
39 Uralsib / Уралсиб (2008). 'Capital Markets' Prospects. Credit Crisis is Changing the Game Rules. Перспективы рынков капитала. Кредитный кризис меняет правила игры.' Uralsib, Debt Capital Market Research Department. Presentation at the $5^{\text {th }}$ Federal Investment Forum, Moscow, 18 Nov. 2008. http://www.fif.rcb.ru/2008/prezentation/ginsbyrg.ppt (accessed on 30 Oct. 2009)

$\underline{\text { www.deloros.ru }}$
} 
Figure 4. Structure of the Accumulated Debt of Russia's Corporate Sector as of 30 October 2008, USD billion

Russia's corporate sector debt structure
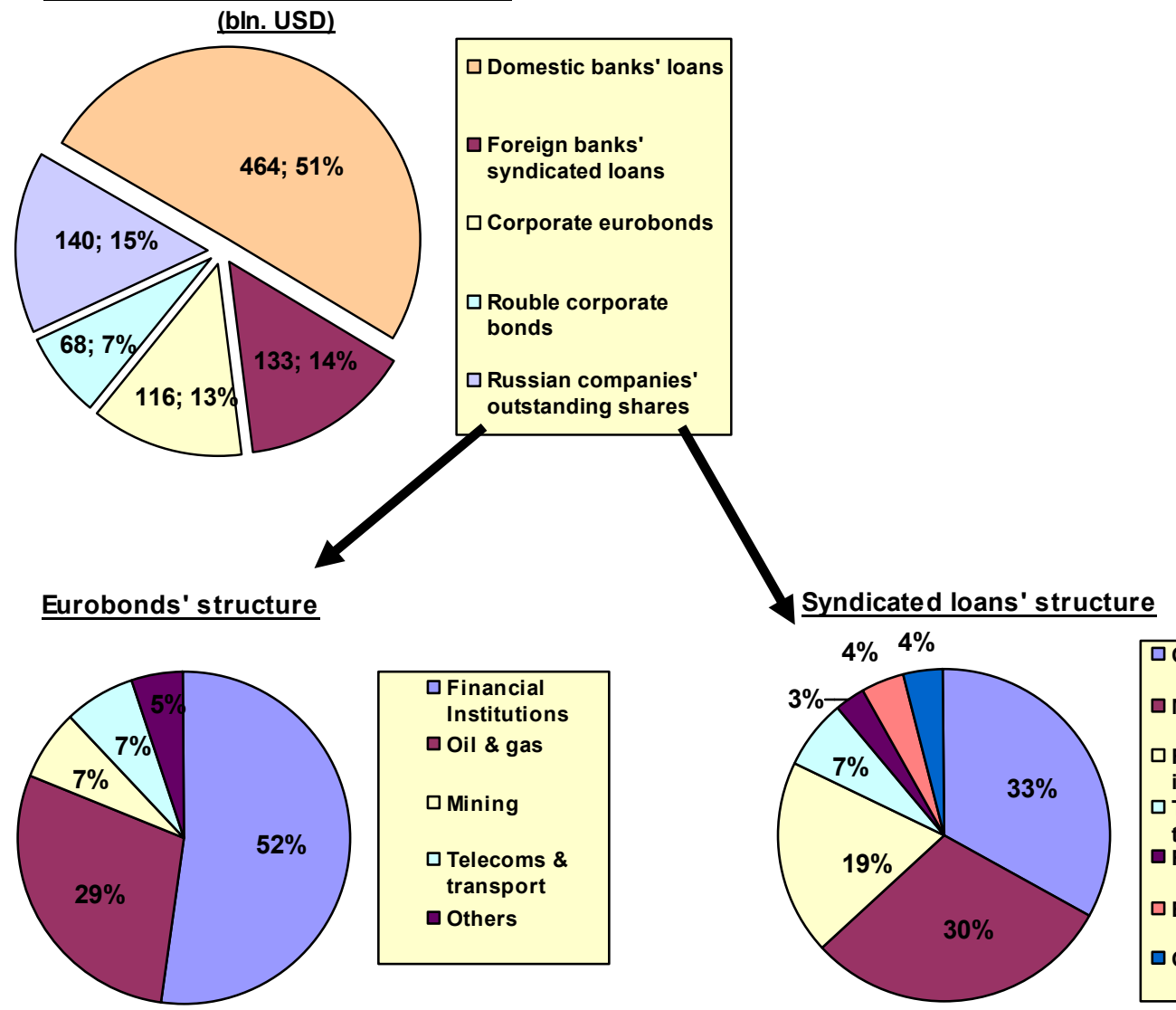

\begin{tabular}{|l|}
$\square$ Oil \& gas \\
$\square$ Mining \\
$\square$ Financial \\
institutions \\
$\square$ Telecoms \& \\
transport \\
Retail \\
$\square$ Energy \& services \\
$\square$ Others
\end{tabular}

Source: Uralsib (2008).

Table 7. Largest Syndicated Loans in Russia Classified by Mandated Lead Arrangers (January 2006 - July 2009)

\begin{tabular}{|l|l|l|l|}
\hline Position & Mandated Lead Arrangers (FI) & $\begin{array}{l}\text { Deal Value (USD } \\
\text { million) }\end{array}$ & No. of Deals \\
\hline 1 & China Development Bank & 25644 & 5 \\
\hline 2 & Vnesheconombank (VEB) & 24240 & 42 \\
\hline 3 & Central Bank of Russia & 20887 & 3 \\
\hline 4 & BNP Paribas & 16508 & 91 \\
\hline 5 & VTB Bank & 15893 & 72 \\
\hline 6 & Societe Generale & 14408 & 76 \\
\hline 7 & ABN AMRO & 13743 & 58 \\
\hline 8 & Sberbank & 13162 & 50 \\
\hline 9 & Citigroup Inc & 11240 & 61 \\
\hline 10 & Barclays & 11132 & 50 \\
\hline 11 & Calyon & 11068 & 71 \\
\hline 12 & ING & 10334 & 83 \\
\hline 13 & EBRD & 6516 & 81 \\
\hline 14 & Deutsche Bank & 6060 & 56 \\
\hline 15 & Bank of Tokyo-Mitsubishi UFJ Ltd & 5950 & 56 \\
\hline 16 & JP Morgan plc & 5853 & 26 \\
\hline
\end{tabular}


[Pure Profit for Russia: Benefits of Responsible Finance]

\begin{tabular}{|l|l|l|l|}
\hline 17 & RBS/ABN AMRO & 5678 & 34 \\
\hline 18 & Commerzbank AG & 5518 & 96 \\
\hline 19 & Morgan Stanley & 5314 & 9 \\
\hline 20 & Sumitomo Mitsui Banking Corp & 5256 & 45 \\
\hline 21 & Gazprombank & 4565 & 10 \\
\hline 22 & RZB & 4195 & 92 \\
\hline 23 & Goldman Sachs International & 3976 & 11 \\
\hline 24 & Natixis & 2986 & 26 \\
\hline 25 & WestLB & 2935 & 39 \\
\hline 26 & BayernLB & 2843 & 39 \\
\hline 27 & HSBC & 2518 & 32 \\
\hline & Bayerische Hypo- & & 18 \\
\hline 28 & Vereinsbank AG - HVB Group & 2103 & 8 \\
\hline 29 & Dresdner Kleinwort Wasserstein & 2084 & 21 \\
\hline 30 & Credit Suisse & 1841 & \\
\hline & TOTAL & USD 264 448 million & \\
\hline
\end{tabular}

Source: Dealogic. 
Table 8. All Project Financing Transactions with the Participation of Russian Borrowers from January 2007 to December 2008

\begin{tabular}{|c|c|c|c|c|c|c|c|}
\hline Borrower & Industry & Loan purpose & $\begin{array}{l}\text { Amount, } \\
\text { USD } \\
\text { million }\end{array}$ & Cur. & $\begin{array}{l}\text { Type of } \\
\text { placement }\end{array}$ & $\begin{array}{l}\text { Synd. } \\
\text { date }\end{array}$ & Mandated lead arrangers \\
\hline Transnefteproduct & Transportation & Project financing & 450 & USD & Syndication & Jan. 07 & VTB \\
\hline $\begin{array}{l}\text { Boguchansky } \\
\text { Aluminium Plant }\end{array}$ & $\begin{array}{l}\text { Non-ferrous } \\
\text { metals }\end{array}$ & Construction of a new power plant & 520 & USD & Syndication & Mar. 07 & $\begin{array}{l}\text { RBS, Barclays Capital, Calyon, } \\
\text { Sberbank }\end{array}$ \\
\hline $\begin{array}{l}\text { ChTPZ (Chelyabinsk } \\
\text { Tube Rolling Plant) }\end{array}$ & Ferrous metals & Project financing / construction project & 195 & EUR & Bilateral loan & May. 07 & EBRD \\
\hline $\begin{array}{l}\text { Guardian Steklo } \\
\text { Ryazan }\end{array}$ & Glass-making & $\begin{array}{l}\text { To assist in financing the construction of a } 750 \\
\text { MTPD float glass plant and glass coating line }\end{array}$ & 83 & RUR & Syndication & May. 07 & BNP Paribas \\
\hline $\begin{array}{l}\text { Guardian Steklo } \\
\text { Ryazan }\end{array}$ & Glass-making & $\begin{array}{l}\text { To assist in financing the construction of a } 750 \\
\text { MTPD float glass plant and glass coating line }\end{array}$ & 83 & RUR & Bilateral loan & May. 07 & EBRD \\
\hline MMK & Ferrous metals & Project financing & 518 & EUR & Syndication & Sep. 07 & RBS, ING, Deutsche Bank \\
\hline $\begin{array}{l}\text { Volkswagen Group } \\
\text { Rus }\end{array}$ & Automotive & Project financing & 213 & RUR & Bilateral loan & Nov. 07 & EBRD \\
\hline $\begin{array}{l}\text { Volkswagen Group } \\
\text { Rus }\end{array}$ & Automotive & Project financing & 862 & RUR & Syndication & Nov. 07 & Calyon, Unicredit Group, ING \\
\hline Eurocement group & $\begin{array}{l}\text { Construction } \\
\text { materials }\end{array}$ & Project financing & 203 & EUR & Syndication & Dec. 07 & BNP Paribas \\
\hline RosEvroDevelopment & Construction & Project financing & 165 & USD & Syndication & Jan. 08 & Goldman Sachs, Gazprombank \\
\hline Severstal & Ferrous metals & Project financing & 223 & EUR & Bilateral loan & Mar. 08 & EBRD \\
\hline Severstal & Ferrous metals & Project financing & 702 & EUR & Syndication & Mar. 08 & ING, Calyon, RZB Group \\
\hline Tatneft & Oil \& gas & Project financing & 2000 & USD & Syndication & Apr. 08 & $\begin{array}{l}\text { BNP Paribas, RBS, Citigroup, } \\
\text { SMBC, Unicredit Group, WestLB }\end{array}$ \\
\hline ICT Group & Diversified & Project financing & 560 & USD & Syndication & Oct. 08 & $\begin{array}{l}\text { VEB, Eurasian Bank for } \\
\text { Development, NOMOS }\end{array}$ \\
\hline \multicolumn{3}{|l|}{ TOTAL } & 6777 & & & & \\
\hline
\end{tabular}

Source: Dealogic. 


\subsection{Investments by IFC and EBRD in Russia}

\section{Kamila Ilyumzhinova and Kevin Smith}

Over the past decade, multilateral banks have become very active market players in Russia providing significant levels of financial support to many companies and banks in the form of term loans and equity participation. In accordance with the development-oriented nature of these particular institutions, both IFC and EBRD place particular emphasis on sustainability, and as a result, the best practices and Performance Standards that they apply in their activities might be considered as the models for the commercial banking sector. IFC and EBRD both include the objective of sustainable development in their mission statements, and as a result, both organisations place a great deal of emphasis on environmental protection and conservation objectives. This policy has translated into two dimensions of activities of IFC and EBRD in Russia.

Firstly, in the majority of instances, IFC and EBRD do not provide significant amounts of funds to "blue-chip" borrowers, whose core business activities are often viewed as environmentally controversial. While large borrowers such as Russian Railways, Lukoil and RusHydro do occasionally approach multilateral banks for loans, their debt structures consist as a rule primarily of funds raised in international debt capital markets via the mechanisms of syndicated loans and Eurobonds.

Secondly, in Russia both IFC and EBRD act as pioneers in climate-related finance directed at increasing the energy efficiency of the Russian economy. In 2005 both institutions launched energy efficiency programs in direct response to the G8 Summit in Gleneagles, where it was demanded that multilateral development banks increase their sustainable energy investments. Both programs extensively cover Russia as a country with immense energy savings potential.

A recent study by the IFC/IBRD ${ }^{41}$ shows that energy efficiency measures hold the potential for impressive impacts in Russia from both an environmental and an economic perspective. The study calculated that investments of USD 320 billion in the Russian economy could lead to energy savings of 45 percent and annual cost savings (for investors and end users) of approximately USD 80 billion. This translates into a payback period on such investments of four years, which should prove particularly attractive to the Russian economy. In terms of resource savings, these efficiency gains translate into 240 billion cubic meters natural gas, 340 billion $\mathrm{kWh}$ electricity, 89 million tons of coal, and 43 million tons of crude oil.

According to the report, achieving the full energy savings potential of 45 percent would also result in a reduction in $\mathrm{CO} 2$ emissions of 793 million tons, which equates to 20 percent of the country's $\mathrm{CO} 2$ emissions of 1990 (the baseline year under the Kyoto Protocol), and fully half these emissions in 2005, creating 10 billion $\mathrm{CO} 2$ emissions reduction units as well as significant health benefits for Russia's citizens. Furthermore, such an achievement would propel Russia to the forefront of the global fight against climate change and increase the competitiveness of the Russian economy through the reduction of production costs.

The experiences of IFC and EBRD are testament to the fact that environmentally responsible and progressive investments are possible in Russia, and that energy efficiency measures in particular can prove extremely attractive for FIs from a commercial viewpoint. The potential market for energy efficiency solutions in Russia is a huge one, and the benefits to be gained, in terms of GHG emissions reductions and the resulting benefits for the climate change agenda, are equally significant. According to the IFC's annual client survey conducted in 2006, the third most important factor for clients in terms of

41 IFC/IBRD (2008). 'Energy Efficiency in Russia: Untapped Reserves'. World Bank Group, Washington D.C. http://www.ifc.org/ifcext/rsefp.nsf/AttachmentsByTitle/FINAL_EE report_Engl.pdf (accessed on 30 Oct. 2009) 
entering into a partnership with IFC was the assistance that the organisation provides in managing environmental and social issues. ${ }^{42}$

\section{Overview of IFC Projects in Russia}

During the course of the 2008 fiscal year, IFC has significantly increased its exposure to the Russian economy, investing more than USD 760 million, in comparison with investment figures of USD 542 million and USD 527 million in 2007 and 2006 respectively (see Table 9 for more details). Since the beginning of its operations in Russia, IFC has invested a total of USD 4.5 billion in more than 180 projects in Russia, covering a variety of sectors including agribusiness, manufacturing, energy and small and medium-sized enterprises as of the end of June 2009. Over the past several years, IFC has also collaborated with EBRD in extending joint financing to several Russian projects.

Table 9. IFC Loans to Russian Borrowers

\begin{tabular}{|c|c|c|c|}
\hline Borrower & Type & $\begin{array}{l}\text { Amount } \\
\text { (USD } \\
\text { million) }\end{array}$ & $\begin{array}{l}\text { TOTAL } \\
\text { (USD million) }\end{array}$ \\
\hline \multicolumn{4}{|c|}{2006} \\
\hline Delta Leasing & Loans - Finance & 16 & \multirow{8}{*}{$\begin{array}{c}265 \\
\text { (92 percent - } \\
\text { loans to } \\
\text { corporations, } \\
8 \text { percent - } \\
\text { to Fls) }\end{array}$} \\
\hline Trio Invest & $\begin{array}{l}\text { Loans - Transport and } \\
\text { Warehousing }\end{array}$ & 20 & \\
\hline OMK Group & Loans - Metallurgy & 70 & \\
\hline Primsotsbank & Loans - Finance & 4 & \\
\hline TV3 & Loans - Communication & 22 & \\
\hline Pilkington Glass & Loans - Manufacturing & 53 & \\
\hline Electro-Com & Loans - Telecoms & 25 & \\
\hline Concordia & Loans - Food \& Beverages & 55 & \\
\hline \multicolumn{4}{|c|}{2007} \\
\hline Prof-Media & Loans - Information & 50 & \multirow{11}{*}{$\begin{array}{c}615 \\
\text { (54 percent - } \\
\text { loans to } \\
\text { corporations, } \\
46 \text { percent - } \\
\text { to Fls) }\end{array}$} \\
\hline Absolut Bank & Loans - Finance & 30 & \\
\hline MDM Bank & Loans - Finance & 100 & \\
\hline Chuvashavtodor & Loans - Construction & 49 & \\
\hline Brunswick Rail Leasing & $\begin{array}{l}\text { Loans - Transportation and } \\
\text { Warehousing }\end{array}$ & 100 & \\
\hline Daido Metal/ ZMZ Bearings & Loans - Manufacturing & 5 & \\
\hline Scanfert Oy via Ava Peter & Loans - Healthcare & 26 & \\
\hline Sodruzhestvo & Loans - Agriculture & 50 & \\
\hline RosVodoKanal & Loans - Utilities & 25 & \\
\hline Belgrankorm Holding & Loans - Agriculture & 30 & \\
\hline Ursa Bank & Loans - Finance & 150 & \\
\hline \multicolumn{4}{|c|}{2008} \\
\hline Home Center & Loans - Wholesale and Retail & 67 & \multirow{9}{*}{$\begin{array}{l}\text { (51 percent - } \\
\text { loans to } \\
\text { corporations, } \\
49 \text { percent - } \\
\text { to Fls) }\end{array}$} \\
\hline Posuda Ltd. & Loans - Manufacturing & 40 & \\
\hline Locko Bank & Loans - Finance & 40 & \\
\hline MDM Bank & Loans - Finance & 385 & \\
\hline Heliopark & Loans - Hotels & 50 & \\
\hline Kronostar & Loans - Wood & 60 & \\
\hline Megalogix & Loans - Real Estate & 105 & \\
\hline $\mathrm{BAC}$ & Loans - Information & 10 & \\
\hline Freight One & Loans - Transportation & 110 & \\
\hline & January - June 2009 & & \\
\hline
\end{tabular}

${ }^{42}$ Independent Evaluation Group (2008). 'Environmental Sustainability: An Evaluation of World Bank Group Support'. World Bank Group Independent Evaluation Group, Washington http://web.worldbank.org/WBSITE/EXTERNAL/EXTOED/EXTENVIRONMENT/0,, contentMDK:21826882 menuPK:468 1948 pagePK:64829573 piPK:64829550 theSitePK:4681890 isCURL:Y,00.html (accessed on 30 Oct. 2009) 


\begin{tabular}{|c|c|c|c|}
\hline Borrower & Type & $\begin{array}{l}\text { Amount } \\
\text { (USD } \\
\text { million) }\end{array}$ & $\begin{array}{l}\text { TOTAL } \\
\text { (USD million) }\end{array}$ \\
\hline FactorRus & Loans - Finance & 10 & \multirow{9}{*}{$\begin{array}{c}197 \\
\text { (95 percent - } \\
\text { loans to } \\
\text { corporations, } \\
5 \text { percent - } \\
\text { to Fls) }\end{array}$} \\
\hline KuibyshevAzot & Loans - Chemicals & 20 & \\
\hline $\begin{array}{ll}\text { Upravlenie } & \text { Zakazchika } \\
\text { Zhilischno-Kommunalnogo }\end{array}$ & & & \\
\hline Khozyaistva & Loans - Utility & 8 & \\
\hline Miratorg & Loans - Agriculture & 90 & \\
\hline Energomera & Loans - Manufacturing & 10 & \\
\hline Allianz Eurasia & Loans - Health Care & 20 & \\
\hline Kulon-Yugros & Loans - Warehousing & 14 & \\
\hline Avtokran & Loans - Manufacturing & 25 & \\
\hline
\end{tabular}

Source: Dealogic.

Note: In order to derive comparable loan figures, a "filtering" methodology has been applied to the IFC investment project data, in order that all equity and "mezzanine" components might be excluded. However, these figures are subject to revision, as in some cases syndicated amounts to the commercial banks have not been identified, hence the commitments were attributed fully to IFC.

This data should not be interpreted as representing the total commitment of IFC to the Russian banking sector, since the organisation not only supports the Russian financial system via the lending mechanisms, but also very often through equity participation.

In 2005, the IFC established the Sustainable Energy Finance Program in Russia. Under this initiative, projects are eligible for financing if they are either introducing state-of-the-art energy efficient technology, or they are part of an industrial modernisation effort which will decrease energy consumption per unit of output, or they are introducing renewable energy technologies. Energy efficiency impacts must be substantial and the payback period must be less than five years. Only established technologies may be introduced, and companies applying for funding must be less than 50 percent state-owned. The first successes under this Program have been achieved in Rostov-on-Don, where IFC is working with Center-Invest Bank in providing loans for energy efficiency measures. Another example of the program's implementation is IFC's USD 75 million loan and equity investment to Nitol Solar company that since 2006 have been trying to enter the rapidly growing global renewable energy market by producing polycrystalline silicon (PCS), a vital ingredient for the construction of photovoltaic devices. The loan will help increase the production of PCS through the construction of a new manufacturing facility. This was followed by a number of other energy-efficiency projects across various industries in Russia.

\section{Overview of EBRD Projects in Russia}

Russia has traditionally held the largest single country exposure, and been one of the principal priority investment targets for the European Bank for Reconstruction and Development (EBRD). As of 31 March 2009, the total number of projects approved by EBRD in Russia was 564, with a total project value of approximately EUR 39.7 billion (see Table 10 for more details).

EBRD's portfolio structure has changed significantly over the recent years, as the bank has increased its participation in the energy sector from 5.0 percent in 2004, to 15.4 percent as of the first quarter of 2009. Similar changes can be seen in the geographical distribution of the portfolio, as EBRD has directed greater resources to the outlying regions of the country; the share of annual investments outside Moscow and St. Petersburg has increased from 71 percent of the total book in 2005, to 86 percent as of the first quarter of 2009. Furthermore, EBRD has transformed from being primarily a lending institution into a significant equity investor, with large acquisitions in the Russian market, primarily in the form of equity participation in Russian FIs such as Spurt Bank, Primsotsbank, and RESO Insurance. In quantitative 
terms, the share of equity projects in EBRD's total portfolio has increased from 13 percent in 2005 to 27 percent as of the first quarter of 2009.

Table 10. EBRD Loans to Russian Borrowers

\begin{tabular}{|c|c|c|c|}
\hline Borrower & Type & $\begin{array}{l}\text { Amount } \\
\text { (EUR } \\
\text { million) }\end{array}$ & $\begin{array}{l}\text { TOTAL } \\
\text { (EUR million) }\end{array}$ \\
\hline \multicolumn{4}{|c|}{2006} \\
\hline Yug Rusi & Loan - Agriculture & 147 & \multirow{24}{*}{$\begin{array}{c}1,272 \\
\text { (66 percent - } \\
\text { loans to } \\
\text { corporations, } \\
34 \text { percent - } \\
\text { to Fls) }\end{array}$} \\
\hline Saratov Shopping centre & Loan - Construction & 36 & \\
\hline LG Russia & Loan - Electronics & 7 & \\
\hline DeltaLeasing & Loan - Finance & 5 & \\
\hline URSA & Loan - Finance & 15 & \\
\hline Mid-sized banks & Loan - Finance & 110 & \\
\hline Absolut Bank & Loan - Finance & 88 & \\
\hline Bank of St. Petersburg & Loan - Finance & 22 & \\
\hline MDM Bank & Loan - Finance & 58 & \\
\hline SREI Leasing & Loan - Finance & 5 & \\
\hline VTB - RFS & Loan - Finance & 110 & \\
\hline Center-Invest Bank & Loan - Finance & 24 & \\
\hline Lenta II & Loan - Food & 37 & \\
\hline Wienerberger Russia I & Loan - Manufacturing & 11 & \\
\hline $\begin{array}{l}\text { CHTPZ Group/ Pervouralsk New } \\
\text { Pipe Plant }\end{array}$ & Loan - Manufacturing & 141 & \\
\hline AR Carton & Loan - Manufacturing & 9 & \\
\hline RusHydro & $\begin{array}{l}\text { Loan - Power and } \\
\text { Energy }\end{array}$ & 190 & \\
\hline Ivanovskoe Estate & Loan - Real Estate & 45 & \\
\hline Enforta & $\begin{array}{l}\text { Loan - Telecoms and } \\
\text { Media }\end{array}$ & 4 & \\
\hline Wagon Financing/ Huolintakeskus & Loan - Transport & 16 & \\
\hline Sukhoi Civil Aircraft Company & Loan - Transport & 100 & \\
\hline Stora Enso & $\begin{array}{l}\text { Loan - Wood and } \\
\text { Paper }\end{array}$ & 19 & \\
\hline Stora Enso & $\begin{array}{l}\text { Loan - Wood and } \\
\text { Paper }\end{array}$ & 29 & \\
\hline Stora Enso & $\begin{array}{l}\text { Loan - Wood and } \\
\text { Paper }\end{array}$ & 45 & \\
\hline \multicolumn{4}{|c|}{2007} \\
\hline Lukoil & Loan - Oil \& Gas & 219 & \multirow{18}{*}{$\begin{array}{l}2,699 \\
\text { (93 percent - } \\
\text { loans to } \\
\text { corporations, } \\
7 \text { percent - to } \\
\text { Fls) }\end{array}$} \\
\hline Autocrane & Loan - Manufacturing & 29 & \\
\hline Element Leasing & Loan - Finance & 7 & \\
\hline Rosmorport & Loan - Transport & 70 & \\
\hline Promsvyazbank & Loan - Finance & 73 & \\
\hline Chelyabinsk Tube Rolling Plant & Loan - Manufacturing & 58 & \\
\hline Chelyabinsk Tube Rolling Plant & Loan - Manufacturing & 145 & \\
\hline Guardian Steklo Ryazan & Loan - Manufacturing & 122 & \\
\hline Azbuka vkusa & Loan - Food & 37 & \\
\hline Bank Kazansky & Loan - Finance & 7 & \\
\hline Promsvyazleasing & Loan - Finance & 22 & \\
\hline $\begin{array}{l}\text { General Motors Russian Assembly } \\
\text { Plant }\end{array}$ & Loan - Manufacturing & 110 & \\
\hline Center-Invest Bank & Loan - Finance & 16 & \\
\hline Center-Invest Bank & Loan - Finance & 16 & \\
\hline Bank Kedr & Loan - Finance & 12 & \\
\hline Severstal & Loan - Manufacturing & 500 & \\
\hline Volkswagen Group & Loan - Manufacturing & 750 & \\
\hline Fazer Bakeries & Loan - Food & 99 & \\
\hline
\end{tabular}


[Pure Profit for Russia: Benefits of Responsible Finance]

\begin{tabular}{|c|c|c|c|}
\hline Borrower & Type & $\begin{array}{l}\text { Amount } \\
\text { (EUR } \\
\text { million) }\end{array}$ & $\begin{array}{l}\text { TOTAL } \\
\text { (EUR million) }\end{array}$ \\
\hline Inpromleasing & Loan - Transport & 142 & \\
\hline SKB Bank & Loan - Finance & 17 & \\
\hline NBD Bank & Loan - Finance & 4 & \\
\hline Stora Enso - Balabanovo plant & $\begin{array}{l}\text { Loan - Wood and } \\
\text { Paper }\end{array}$ & 23 & \\
\hline Taganrog Teploenergo & Loan - Energy & 6 & \\
\hline Vostochny Express Bank & Loan - Finance & 21 & \\
\hline Krasnodar Glass Packaging Plant & $\begin{array}{l}\text { Loan - Food and } \\
\text { Beverage }\end{array}$ & 38 & \\
\hline Monetka & Loan - Food & 44 & \\
\hline Globus & Loan - Food & 112 & \\
\hline \multicolumn{4}{|c|}{2008} \\
\hline Moscow Integrated Power Company & Loan - Energy & 100 & \multirow{26}{*}{$\begin{array}{l}1,772 \\
\text { (92 percent - } \\
\text { loans to } \\
\text { corporations, } \\
8 \text { percent - to } \\
\text { Fls) }\end{array}$} \\
\hline Okey & Loan - Food & 200 & \\
\hline Bank of Saint Petersburg & Loan - Finance & 25 & \\
\hline Credit Bank of Moscow & Loan - Finance & 10 & \\
\hline Europlan & Loan - Finance & 25 & \\
\hline Sovcombank & Loan - Finance & 28 & \\
\hline Lipetsk Municipal Energy Company & Loan - Energy & 20 & \\
\hline Detsky Mir & Loan - Retail & 50 & \\
\hline Sinara Transport Machines & Loan - Manufacturing & 65 & \\
\hline Enforta & $\begin{array}{l}\text { Loan - Telecoms and } \\
\text { Media }\end{array}$ & 15 & \\
\hline Rosevrobank & Loan - Finance & 30 & \\
\hline First Freight Company & Loans - Transport & 316 & \\
\hline $\begin{array}{l}\text { Petropavlovsk-Kamchatskiy } \\
\text { Municipal Water Project }\end{array}$ & Loans - Utility & 11 & \\
\hline Volzhski Vodokanal & Loans - Utility & 10 & \\
\hline Carcade Ltd. & Loan - Finance & 50 & \\
\hline $\begin{array}{l}\text { Yugansktransteploservis/Yuganskvo } \\
\text { dokanal }\end{array}$ & Loans - Utility & 15 & \\
\hline Petra 8 & Loans - Property & 150 & \\
\hline Pechora Energy & Loans - Oil \& Gas & 45 & \\
\hline Credit Bank of Moscow & Loans - Finance & 30 & \\
\hline OGK-5 & Loans - Energy & 103 & \\
\hline Kuzbassky Pischekombinat & Loans - Agriculture & 20 & \\
\hline Volga Industrial Park & Loans - Property & 34 & \\
\hline Surgut Municipal Unitary Enterprise & Loans - Utility & 6 & \\
\hline Integra Group & $\begin{array}{ll}\text { Loans - } & \text { Natural } \\
\text { Resources } & \end{array}$ & 300 & \\
\hline Ken Pak Zavod Upakovki & Loans - Agriculture & 50 & \\
\hline $\begin{array}{l}\text { Ruscam - Kirishi and Ruscam } \\
\text { Odessa }\end{array}$ & Loans - Food & 65 & \\
\hline \multicolumn{4}{|c|}{ January - June 2009} \\
\hline Belaya Dacha Trading & Loans - Agriculture & 7 & \multirow{9}{*}{$\begin{array}{c}2,205 \\
\text { (71 percent - } \\
\text { loans to } \\
\text { corporations, } \\
29 \text { percent - } \\
\text { to Fls) }\end{array}$} \\
\hline Irkutsk Oil \& Gas Company & Loans - Oil \& Gas & 90 & \\
\hline VTB-24 & Loans - Finance & 112 & \\
\hline Raven Russia Logistics & Loans - Property & 30 & \\
\hline Small Business Credit Bank & Loans - Finance & 56 & \\
\hline Yugra Energy Company & Loans - Power & 34 & \\
\hline Eczacibasi Vitra Plitka & $\begin{array}{l}\text { Loans } \\
\text { Manufacturing }\end{array}$ & 11 & \\
\hline Kalina Concern & $\begin{array}{l}\text { Loans } \\
\text { Manufacturing }\end{array}$ & 30 & \\
\hline Autocrane & Loans - Machinery & 26 & \\
\hline
\end{tabular}




\begin{tabular}{|c|c|c|c|}
\hline Borrower & Type & $\begin{array}{l}\text { Amount } \\
\text { (EUR } \\
\text { million) }\end{array}$ & $\begin{array}{l}\text { TOTAL } \\
\text { (EUR million) }\end{array}$ \\
\hline Vodoteplosnab & Loans - Utilities & 16 & \\
\hline $\begin{array}{l}\text { Russian Participating Banks (Energy } \\
\text { efficiency) }\end{array}$ & Loans - Finance & 300 & \\
\hline Surgut Municipal Unitary Enterprise & Loans - Utilities & 36 & \\
\hline Transcontainer & Loans - Transport & 75 & \\
\hline TGK-13 & Loans - Energy & 56 & \\
\hline Novolipetsk Metallurgical Company & Loans - Metallurgy & 250 & \\
\hline SibStroylnvest & Loans - Property & 40 & \\
\hline Sistema & Loans- Diversified & 120 & \\
\hline Bank Saint-Petersburg & Loans - Finance & 56 & \\
\hline Yug Rusi & Loans - Agriculture & 112 & \\
\hline Troika Dialogue & Loans - Finance & 112 & \\
\hline LR TEK & Loans - Utilities & 20 & \\
\hline TGK-8 & Loans - Energy & 240 & \\
\hline Russian Railways & Loans - Transport & 375 & \\
\hline
\end{tabular}

Source: Dealogic.

Note: In order to derive comparable loan figures, a "filtering" methodology has been applied to the EBRD investment project data, in order that all equity and "mezzanine" components might be excluded. However, these figures are subject to revision, as in some cases syndicated amounts to the commercial banks have not been identified, hence the commitments were attributed fully to EBRD.

This data should not be interpreted as representing the total commitment of EBRD to the Russian economy, since the organisation not only supports the Russian financial system and industry via the lending mechanisms, but also very often through equity participation.

EBRD's Sustainable Energy Initiative (SEI), also launched in 2005, is similar to the IFC's Sustainable Energy Finance Program. With Phase 1 of the Initiative completed in 2008, EBRD has invested EUR 2.7 billion into 166 projects in 24 countries. Of those investments, 64 percent were in the private sector and the total value of these projects was over EUR 14 billion. The SEI represents 20 percent of EBRD's total financing, and has thus far saved approximately 21 million tonnes of annual CO2 emissions. ${ }^{43}$ SEI investments in Russia totaled at EUR 755 million, with a total project size over EUR 3.7 billion. ${ }^{44}$ These investments took place in the following areas: industrial energy efficiency, power sector energy efficiency, renewable energy, municipal infrastructure energy efficiency, carbon market development, and Sustainable Energy Financing Facilities (SEFF), which comprises the financing of credit lines via financial intermediaries.

As of mid 2009, EBRD was in the process of creating a Russian Sustainable Energy and Carbon Finance Facility (RSECF), a facility to on-lend up to EUR 300 million to Russian banks, for loans to sustainable energy projects within the private sector. A pilot project for this program, with an investment of EUR 10 million, was executed together with Center-Invest Bank in 2007. Another example of energy efficiency financing is a loan to Severstal, ${ }^{45}$ one of Russia's largest steel manufacturing companies, which was signed in 2007. EBRD arranged a loan of EUR 600 million (including EUR 150 million of EBRD's own funds) for an ambitious energy efficiency overhaul of Severstal's plant in Cheropovets aimed at

43 EBRD (2009). 'Sustainable Energy Initiative: Action and Results 2006-2009'. EBRD, London. http://www.ebrd.com/pubs/cs/sei.pdf (accessed on 30 Oct. 2009)

${ }^{44}$ McCallion, T. (2009). 'EBRD: Mainstreaming Energy Efficiency across Banking Operations'. Presentation given at the 'Promotion of Sustainable Finance Mechanism in Russia' conference, Moscow, 29 Apr. 2009. http://wwf.ru/data/events/3/tmccallion ebrd.pdf (accessed on 30 Oct. 2009)

${ }^{45}$ EBRD feature story. 7 Apr. 2008. http://www.ebrd.com/new/stories/2008/080407.htm (accessed on 30 Oct. 2009) 
reducing the company's consumption of electricity $(6 \mathrm{MWh}$ per annum, which is more than the entire consumption of some small countries, such as Moldova) by 10 percent, and consumption of natural gas by 3.5 percent. This equates to a cut in $\mathrm{CO} 2$ emissions of 1 million tons per annum. Payback periods for some of the projects at Cheropovets are expected to be less than one year, making these a particularly attractive prospect in the light of increasing energy prices.

A further example of a 'green' loan is the one provided to Lukoil in 2007. This USD 300 million loan is to be applied in all countries in which Lukoil is active, and is intended to introduce measures to enhance environmental, health and safety standards of the company's facilities. Specific activities in this regard include pipeline replacements, reductions in gas flaring, energy efficiency measures through modernisation and improvements in employee safety. The overall objective is to make these facilities compliant not only with relevant national laws, but also with international and EU regulations. The payback period for the project is relatively long, and as a result the tenure of the unsecured primary loan of USD 150 million is ten years, while that of the syndicated secondary loan, also of USD 150 million, is seven years. ${ }^{46}$

\subsection{International Syndicated Loans: A Sectoral Analysis}

\section{Kamila Ilyumzhinova}

The following two sections of this study (Sections 2.4 and 2.5) have the objective of quantifying the scope of environmental responsibility exhibited by foreign and domestic FIs in Russia. This will be done by trying to identify key lenders to each of the environment-intensive industries of Russia.

However, there are significant data limitations that have precluded this report from fully achieving this goal:

- Industry developments that are known as most controversial from the environmental viewpoint, for example in the Russian oil and gas sector, rely predominantly on syndicated rather than bilateral loans. Information on the actual commitments of each FI participating in syndicated loans under consideration has not been available, and it has been therefore impossible to quantify exposure of individual foreign and domestic FIs to environment-intensive sectors of the Russian economy;

- In their IFRS statements different banks use various classifications of borrowers by industry, and these may or may not be different from the classification employed by the loans databases such as Dealogic and Loans.cbonds.info. For example, Petrocommerce Bank included the oil segment as part of their lending into the energy sector, while VEB included the military segment as part of the manufacturing sector. Therefore, by drawing data from all available sources this report uses lending statistics to provide a big picture overview rather than focus on each industry or lender in detail;

- While being the most comprehensive available sources of data, the databases used for this analysis such as the Dealogic Loanware application and Loans.cbonds.info do not capture a significant number of loan transactions. For example, there are considerable mismatches between the number of loans extended by IFC to Russian clients between January 2006 and July 2009 registered in the Dealogic Loanware database (11) and reported by the IFC itself (36). Therefore a lot of data used in this report can be revised upwards.

This section of the study presents the principal findings of the sectoral analysis of international syndicated loans. The borrowers have been classified according to the following categories, with the ten largest transactions being identified in each sector:

- Chemicals, mining and manufacturing

- Oil \& gas

${ }^{46}$ EBRD feature story. 21 May 2007. http://www.ebrd.com/new/pressrel/2007/070521b.htm (accessed on 30 Oct. 2009) 
- Energy and utilities

- Real estate, construction and property

- Transport and telecommunications

- Agriculture, food and forestry

- Finance

For the purposes of the study, the first six industries are classified as environment-intensive, though their individual footprints vary a lot from each other. The finance sector is understood as environmentallyneutral, although some of the funds raised by the Russian financial intermediaries in the international capital markets are channeled to environment-intensive activities in Russia, too.

Table 11. Ten Largest Loans in the Russian Chemicals, Mining, Machinery and Manufacturing Sector (January 2006 - July 2009)

\begin{tabular}{|c|c|c|}
\hline Borrower & $\begin{array}{l}\text { Total Deal Value } \\
\text { (USD million) }\end{array}$ & Mandated Lead Arrangers \\
\hline Norilsk Nickel & 6000,000 & $\begin{array}{l}\text { BNP Paribas, SG Corporate \& Investment } \\
\text { Banking, Bank of Tokyo-Mitsubishi UFJ Ltd, } \\
\text { Calyon, HypoVereinsbank AG, ING, Natixis, } \\
\text { Sumitomo Mitsui Finance Dublin Ltd (SMFD) }\end{array}$ \\
\hline United Co Rusal & 4500,000 & $\begin{array}{l}\text { BNP Paribas, Barclays, Bayerische Hypo- und } \\
\text { Vereinsbank AG - HVB Group, Calyon, } \\
\text { Credit Suisse, ING, Merrill Lynch, Natixis, } \\
\text { RBS/ABN AMRO }\end{array}$ \\
\hline Evraz Group & 3214,000 & $\begin{array}{l}\text { BNP Paribas, Bank of Tokyo-Mitsubishi UFJ Ltd, } \\
\text { Barclays, Calyon, Commerzbank AG, } \\
\text { Deutsche Bank, ING, RBS/ABN AMRO, } \\
\text { Sumitomo Mitsui Banking Corp, UBS }\end{array}$ \\
\hline United Co Rusal & 2350,000 & $\begin{array}{l}\text { ABN AMRO, BNP Paribas, Calyon, Citigroup Inc, } \\
\text { Natixis, Bank of Tokyo-Mitsubishi UFJ Ltd, } \\
\text { Barclays, Bayerische Hypo- und Vereinsbank AG } \\
-\quad \text { HVB Group, Bayerische Landesbank, } \\
\text { Commerzbank AG, ING, SG Corporate \& } \\
\text { Investment Banking, Sumitomo Mitsui Banking } \\
\text { Corp }\end{array}$ \\
\hline $\begin{array}{l}\text { Russian } \\
\text { Aluminium OAO } \\
\text { - Rusal }\end{array}$ & 2000,000 & $\begin{array}{l}\text { ABN AMRO, BNP Paribas, Calyon, Citigroup Inc, } \\
\text { Bank of Tokyo-Mitsubishi UFJ Ltd, BayernL, } \\
\text { HSBC, HSH Nordbank, Mizuho Corporate Bank } \\
\text { Ltd, Natexis Banques Populaires SA, Sumitomo } \\
\text { Mitsui Banking Corp }\end{array}$ \\
\hline Mechel & 2000,000 & $\begin{array}{l}\text { BNP Paribas, Calyon, Natixis, RBS/ABN AMRO, } \\
\text { SG Corporate \& Investment Banking, } \\
\text { Sumitomo Mitsui Banking Corp, Commerzbank } \\
\text { AG }\end{array}$ \\
\hline Evraz Group & 1800,000 & $\begin{array}{l}\text { Credit Suisse, UBS, BNP Paribas, Bank Austria } \\
\text { Creditanstalt AG, Bank of Tokyo-Mitsubishi Ltd, } \\
\text { Calyon, Citigroup Inc, Commerzbank AG, Fortis, } \\
\text { Kreditanstalt fuer Wiederaufbau - KfW, } \\
\text { RZB, Sumitomo Mitsui Banking Corp }\end{array}$ \\
\hline $\begin{array}{l}\text { Novolipetsk } \\
\text { Steel }\end{array}$ & 1600,000 & $\begin{array}{l}\text { BNP Paribas, Bank of Tokyo-Mitsubishi UFJ Ltd, } \\
\text { Bayerische Hypo- und Vereinsbank AG - HVB } \\
\text { Group, Deutsche Bank, SG Corporate \& } \\
\text { Investment Banking, Sumitomo Mitsui Banking } \\
\text { Corp, Fortis, RBS/ABN AMRO }\end{array}$ \\
\hline Metalloinvest & 1600,000 & $\begin{array}{l}\text { BNP Paribas, Bank of Tokyo-Mitsubishi UFJ Ltd, } \\
\text { Bayerische Hypo- und Vereinsbank AG - HVB } \\
\text { Group, Calyon, Commerzbank AG, Deutsche }\end{array}$ \\
\hline
\end{tabular}




\begin{tabular}{|l|l|l|}
\hline & & $\begin{array}{l}\text { Bank, ING, Natixis, OrgresBank OAO, RBS/ABN } \\
\text { AMRO, Rabobank International, SG Corporate \& } \\
\text { Investment Banking, Sumitomo Mitsui Banking } \\
\text { Corp Europe Ltd }\end{array}$ \\
\hline $\begin{array}{l}\text { EuroChem } \\
\text { Chineral }\end{array}$ & $\begin{array}{l}\text { BNP Paribas, Bank of Tokyo-Mitsubishi UFJ Ltd, } \\
\text { Barclays, Bayerische Hypo- und Vereinsbank AG } \\
\text { - HVB Group, ING, OrgresBank OAO, RBS/ABN } \\
\text { AMRO, SG Corporate \& Investment Banking, } \\
\text { Sumitomo Mitsui Banking Corp }\end{array}$ \\
\hline TOTAL & 1500,000 & \\
\hline
\end{tabular}

Source: Dealogic.

The chemicals, mining and manufacturing sector cause significant impacts on the environment in three dimensions: a) depletion of natural resources as a result of extractive activities; b) waste and emissions from processing of raw materials; c) energy consumption. Therefore, the financial sector can play an important role in minimizing the negative impact of this sector on the environment through both funding modernisation of their industrial processes and starting a dialogue with the borrowers about possible environmental risks of their planned expansion activities. For example, in 2006, one of Russia's largest metal producers, Evraz, acquired the Highveld Steel and Vanadium Corporation Ltd in South Africa for USD 678 million $^{47}$. The assets acquired by Evraz were generally characterised by poor environmental performance. In October 2007, an inspection by the South African environmental police on Highveld Steel's Vanchem vanadium plant exposed a number of transgressions of environmental legislation. These transgressions undoubtedly contributed to the situation in which Evraz was unable to recoup its investment when it was forced by European competition authorities to divest itself of some of Highveld's assets ${ }^{48}$.

The chemicals, mining and manufacturing sector has been traditionally largely dependant on international capital markets, with limited funds raised inside Russia. The world's largest aluminium producer - United Company Rusal, both directly and through its subsidiaries, - was the most frequent borrower in international capital markets in the sector. In terms of the finance providers, BNP Paribas was the only FI that participated in each of the ten largest syndicated loans extended to the Russian mining and metal companies, while Royal Bank of Scotland/ABN AMRO and Societe Generale Bank were also very active lenders in this sector.

Table 12. Ten Largest Loans in the Russian Oil and Gas Sector (January 2006 - July 2009)

\begin{tabular}{|l|l|l|}
\hline Borrower & $\begin{array}{l}\text { Total Deal Value } \\
\text { (USD million) }\end{array}$ & Mandated Lead Arrangers \\
\hline Rosneft & 15000,000 & China Development Bank \\
\hline Rosneft & 13000,000 & $\begin{array}{l}\text { ABN AMRO, BNP Paribas, Barclays, Calyon, } \\
\text { Citigroup Inc, Goldman Sachs International, JP } \\
\text { Morgan plc, Morgan Stanley }\end{array}$ \\
\hline Transneft & 10000,000 & China Development Bank \\
\hline $\begin{array}{l}\text { RN-Razvitiye } \\
\text { (Rosneft } \\
\text { subsidiary) }\end{array}$ & 9000,000 & $\begin{array}{l}\text { ABN AMRO, BNP Paribas, Barclays, Calyon, } \\
\text { Citigroup Inc, Goldman Sachs International, JP } \\
\text { Morgan plc, Morgan Stanley }\end{array}$ \\
\hline Gazprom & 5450,000 & $\begin{array}{l}\text { ABN AMRO, Morgan Stanley, SG Corporate \& } \\
\text { Investment Banking }\end{array}$ \\
\hline Gazprom & 5053,570 & $\begin{array}{l}\text { ABN AMRO, Morgan Stanley Bank International } \\
\text { Ltd, SG Corporate \& Investment Banking }\end{array}$ \\
\hline Gazprom & 3500,000 & \multicolumn{2}{|l}{} \\
\hline
\end{tabular}

\footnotetext{
${ }^{47}$ Smart Money. 9 Oct. 2006. http://www.smoney.ru/article.shtml?2006/10/09/1476

${ }^{48}$ Business Report. 24 Apr. 2007. http://www.busrep.co.za/index.php?fSectionId=553\&fArticleId=4370487
} 


\begin{tabular}{|c|c|c|}
\hline & & Banking \\
\hline Rosneft & 3425,000 & $\begin{array}{l}\text { BBVA, BNP Paribas, Bank of Tokyo-Mitsubishi } \\
\text { UFJ Ltd, Barclays, BayernLB, WestLB, } \\
\text { Deutsche Bank, ING, JP Morgan plc, Mizuho } \\
\text { Corporate Bank Ltd, OrgresBank OAO, } \\
\text { RBS/ABN AMRO, SG Corporate \& Investment } \\
\text { Banking, Sumitomo Mitsui Banking Corp }\end{array}$ \\
\hline Rosneft & 3300,000 & $\begin{array}{l}\text { ABN AMRO, Barclays, Dresdner Kleinwort } \\
\text { Wasserstein }\end{array}$ \\
\hline Rosneft & 3200,000 & 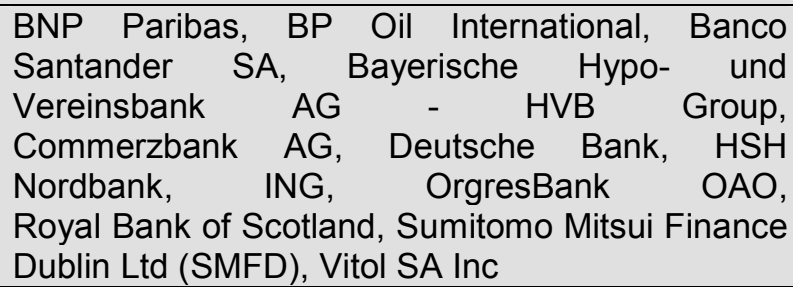 \\
\hline TOTAL & 70928,570 & \\
\hline
\end{tabular}

Source: Dealogic.

Historically, due to the capital-intensive nature of the oil and gas industry, loans into this sector have been amongst the largest in the Russian economy. As very few Russian FIs possess sufficient funds for extensive lending into the sector, both state-owned and private Russian oil and gas companies have tended to raise the majority of their funds in international capital markets, via Eurobond and syndicated loan structures. An illustration of the scale of foreign borrowing by Russian companies operating in this sector, is the fact that in 2007, two of the country's largest state-affiliated companies, Gazprom and Rosneft, raised at least USD 35 billion in international capital markets. Rosneft, Gazprom and Transneft have been the most active borrowers in the Russian oil and gas industry, tapping resources from both syndicated loans and, increasingly, from the China Development Bank, which was the sole lender in of the largest bilateral loans in this sector in January 2006 - July 2009, totaling a record amount of USD 25 billion. RBS/ABN AMRO would appear to be the most significant participant of syndicated loans, having taken part in seven of the ten largest syndicated loans extended to Russian oil and gas producers.

The oil and gas segment has traditionally been highly controversial from the environmental perspective. The environmental challenges facing this industry are in many respects similar to the ones described for the chemicals, mining and manufacturing sector. The fact that the majority of financing for the Russian oil and gas sector originates outside the country, leads to the logical conclusion that international FIs possess a far greater indirect environmental impact in this sector than Russian banks. At the same time, a number of the international FIs that act as lead institutions in financing transactions in the sector, are signatories of the Equator Principles. For example, in March 2007, two Equator Principles signatory institutions - ABN AMRO and Societe Generale - acted as bookrunners in Gazprom's USD 4.5 billion project financing transaction related to the Sakhalin II development.

Table 13. Ten Largest Loans in the Russian Utilities Sector (January 2006 - July 2009)

\begin{tabular}{|l|l|l|}
\hline Borrower & $\begin{array}{l}\text { Total Deal Value } \\
\text { (USD million) }\end{array}$ & Mandated Lead Arrangers \\
\hline EN+ Group Ltd & 750,000 & $\begin{array}{l}\text { Credit Suisse, Deutsche Bank, Goldman } \\
\text { Sachs International, Morgan Stanley, } \\
\text { Natixis, RBS/ABN AMRO, RZB, Barclays, } \\
\text { Caja Madrid }\end{array}$ \\
\hline $\begin{array}{l}\text { Novy Urengoy } \\
\text { Gas \& Chemical } \\
\text { Complex }\end{array}$ & 500,000 & Calyon, RBS/ABN AMRO \\
\hline OGK-5 OAO & 373,281 & RBS/ABN AMRO \\
\hline $\begin{array}{l}\text { Moscow United } \\
\text { Electricity }\end{array}$ & 370,000 & BNP Paribas, Barclays, ING, WestLB \\
\hline
\end{tabular}




\begin{tabular}{|l|l|l|}
\hline $\begin{array}{l}\text { Distribution Co } \\
\text { OJSC - MOESK }\end{array}$ & \\
\hline Mosenergo OAO & 311,608 & Calyon, NordLB \\
\hline Mosenergo OAO & 250,000 & Citigroup Inc, EBRD \\
\hline Lenenergo & 200,000 & Barclays \\
\hline $\begin{array}{l}\text { Inter RAO EES } \\
\text { ZAO }\end{array}$ & 130,000 & $\begin{array}{l}\text { BNP Paribas, Commerzbank AG, Natixis, } \\
\text { VTB Bank OAO }\end{array}$ \\
\hline $\begin{array}{l}\text { Vodokanal of St. } \\
\text { Petersburg }\end{array}$ & 24,911 & EIB \\
\hline $\begin{array}{l}\text { Vodokanal of St } \\
\text { Petersburg }\end{array}$ & 33,981 & Nordic Investment Bank \\
\hline TOTAL & $\mathbf{2 9 4 3 , 7 8 0}$ & \\
\hline
\end{tabular}

Source: Dealogic.

The Russian public utilities segment has a tremendous environmental potential both in terms of GHG emissions reduction and energy savings. In Russia this sector has historically been dependent on the loans provided by international multilateral banks such as the European Investment Bank (EIB), Nordic Investment Bank, etc and state-owned Russian banks, with relatively modest support originating from international debt markets.

Table 14. Ten Largest Loans in the Russian Real Estate, Construction and Property Sector (January 2006 - July 2009)

\begin{tabular}{|c|c|c|}
\hline Borrower & $\begin{array}{l}\text { Total Deal Value } \\
\text { (USD million) }\end{array}$ & Mandated Lead Arrangers \\
\hline $\begin{array}{ll}\text { Corcutt } & \text { Real } \\
\text { Estate SA } & \end{array}$ & 558,495 & Eurohypo AG \\
\hline $\begin{array}{l}\text { Sveza Holdings } \\
\text { Ltd }\end{array}$ & 266,951 & $\begin{array}{l}\text { Bank for Foreign Trade OAO } \\
\text { Vneshtorgbank, Commerzbank AG, Standard } \\
\text { Bank plc, International Moscow Bank ZAO - } \\
\text { MMB }\end{array}$ \\
\hline LSR Group & 194,160 & Deutsche Bank \\
\hline $\begin{array}{l}\text { Hals-Invest } \\
\text { Development }\end{array}$ & 187,000 & Eurohypo AG \\
\hline Profit ZAO & 180,000 & $\begin{array}{lcc}\text { Commerzbank } \quad \text { AG, ING, } & \text { Natixis, } \\
\text { SG Corporate \& Investment Banking } & \end{array}$ \\
\hline LLC Cement & 179,630 & HSBC, RBS/ABN AMRO \\
\hline $\begin{array}{l}\text { RosEvroDevelop } \\
\text { ment OOO }\end{array}$ & 165,000 & $\begin{array}{l}\text { Goldman Sachs International, Gazprombank } \\
\text { ZAO }\end{array}$ \\
\hline $\begin{array}{l}\text { GazOilTrade } \\
\text { O०O }\end{array}$ & 150,000 & $\begin{array}{l}\text { Raiffeisenbank ZAO, Amsterdam Trade Bank } \\
\text { NV }\end{array}$ \\
\hline $\begin{array}{l}\text { Oborne Facility } \\
\text { Ltd }\end{array}$ & 130,000 & Eurohypo AG \\
\hline $\begin{array}{l}\text { Raven Russia } \\
\text { Ltd }\end{array}$ & 89,000 & Aareal Bank AG \\
\hline TOTAL & 2100,240 & \\
\hline
\end{tabular}

Source: Dealogic.

Real estate, construction and property sector plays a particularly important role for raising energy efficiency of the Russian economy, as there is a significant energy saving potential in replacing and retrofitting existing energy-intensive buildings in Russia. This sector is another segment of the Russian economy that is only moderately dependent on the international debt capital markets, with the majority of funds being raised within the country. 
Table 15. Ten Largest Loans in the Russian Transport and Telecommunications Sector (January 2006 - July 2009)

\begin{tabular}{|c|c|c|}
\hline Borrower & $\begin{array}{l}\text { Total Deal Value } \\
\text { (USD million) }\end{array}$ & Mandated Lead Arrangers \\
\hline VimpelCom & 3500,000 & $\begin{array}{l}\text { BNP Paribas, Barclays, Calyon, Citigroup Inc, } \\
\text { HSBC, ING, RBS/ABN AMRO, UBS }\end{array}$ \\
\hline VimpelCom & 3500,000 & $\begin{array}{l}\text { BNP Paribas, Barclays, Calyon, Citigroup Inc, } \\
\text { HSBC, ING, RBS/ABN AMRO, UBS }\end{array}$ \\
\hline $\begin{array}{l}\text { Altimo Holdings } \\
\text { \& Investments } \\
\text { Ltd }\end{array}$ & 1500,000 & Deutsche Bank \\
\hline $\begin{array}{l}\text { Mobile } \\
\text { TeleSystems } \\
\text { OAO - MTS }\end{array}$ & 1330,000 & $\begin{array}{l}\text { HSBC, ING, RZB, ABN AMRO, BNP Paribas, } \\
\text { Bank of Tokyo-Mitsubishi Ltd, } \\
\text { BayernLB, Credit Suisse International, } \\
\text { Sumitomo Mitsui Banking Corp, WestLB }\end{array}$ \\
\hline $\begin{array}{l}\text { Russian } \\
\text { Railways }\end{array}$ & 1100,000 & $\begin{array}{l}\text { BBVA, BNP Paribas, } \\
\text { Creditanstalt AG, Bank of } \\
\text { Ltd, } \\
\text { UFJ } \\
\text { ING, WestLB, Export Development Canadria } \\
\text { EDC, Intesa Sanpaolo Bank Ireland plc, } \\
\text { Nordea Bank AB }\end{array}$ \\
\hline VimpelCom & 739,645 & $\begin{array}{l}\text { BNP Paribas, Bank of Tokyo-Mitsubishi UFJ } \\
\text { Ltd, Barclays, Commerzbank AG, } \\
\text { Standard Bank plc, Sumitomo Mitsui Banking } \\
\text { Corp, WestLB }\end{array}$ \\
\hline VimpelCom & 723,256 & $\begin{array}{l}\text { BNP Paribas, Bank of Tokyo-Mitsubishi UFJ } \\
\text { Ltd, Barclays, Commerzbank AG, } \\
\text { Standard Bank plc, Sumitomo Mitsui Banking } \\
\text { Corp, WestLB }\end{array}$ \\
\hline $\begin{array}{l}\text { Mobile } \\
\text { TeleSystems } \\
\text { OAO - MTS }\end{array}$ & 681,166 & $\begin{array}{l}\text { Absolut Bank ZAO, BNP Paribas, Bank of } \\
\text { America, Bank of China, Bank of China } \\
\text { International } \\
\text { Banque Societe Generale Vostok ZAO - } \\
\text { BSGV, BayernLB, Credit Suisse, Export } \\
\text { Development Canada } \quad \text { EDC, } \\
\text { HSBC, ING, JP Morgan plc, Royal Bank of } \\
\text { Scotland plc, SG Corporate \& Investment } \\
\text { Banking, } \\
\text { Unicredit Bank Austria AG, Unicredit Bank } \\
\text { ZAO, WestLB }\end{array}$ \\
\hline $\begin{array}{l}\text { Comstar UTS } \\
\text { OAO }\end{array}$ & 675,000 & ABN AMRO \\
\hline $\begin{array}{l}\text { Primorsk } \\
\text { International } \\
\text { Shipping Ltd - } \\
\text { PRISCO }\end{array}$ & 530,000 & 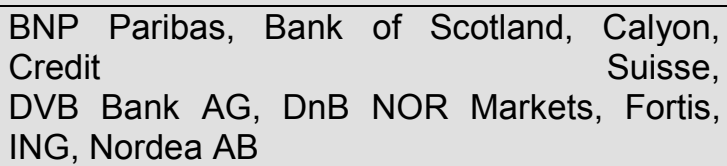 \\
\hline TOTAL & 14279,070 & \\
\hline
\end{tabular}

Source: Dealogic.

In this sector, WWF has historically tracked the activities of Russian Railways and shipping companies whose core business activities present the threat of significant environmental impacts. However, Russian Railways is not particularly dependent on international capital markets, having raised significant loan financing from domestic sources such as Sberbank and VTB, as well as from EBRD. 
Table 16. Ten Largest Loans in the Russian Agriculture, Food and Forestry Sector (January 2006 - July 2009)

\begin{tabular}{|l|l|l|}
\hline Borrower & $\begin{array}{l}\text { Total Deal Value } \\
\text { (USD million) }\end{array}$ & Mandated Lead Arrangers \\
\hline $\begin{array}{l}\text { Baltic Beverages } \\
\text { Holding AB }\end{array}$ & 756,907 & $\begin{array}{l}\text { Citigroup Inc, Danske Bank, } \\
\text { Handelsbanken } \\
\text { Nordea AB }\end{array}$ \\
\hline $\begin{array}{l}\text { llim Eapital } \\
\text { Enterprise }\end{array}$ & 200,000 & $\begin{array}{l}\text { SG Corporate \& Investment Banking, } \\
\text { Banque Societe Generale Vostok ZAO - } \\
\text { BSGV }\end{array}$ \\
\hline Yug Rusi OOO & 186,000 & ABN AMRO, EBRD \\
\hline JFC Group ZAO & 150,000 & ABN AMRO, Commerzbank AG, Alpha Bank \\
\hline $\begin{array}{l}\text { Nastyusha Grain } \\
\text { Co OOO }\end{array}$ & 118,000 & SG Corporate \& Investment Banking \\
\hline $\begin{array}{l}\text { Nastyusha Grain } \\
\text { Co OOO }\end{array}$ & 100,000 & SG Corporate \& Investment Banking \\
\hline EFKO OAO & 30,000 & SG Corporate \& Investment Banking \\
\hline Sucden (Russia) & 25,000 & SG Corporate \& Investment Banking \\
\hline $\begin{array}{l}\text { Nastyusha Grain } \\
\text { Co OOO }\end{array}$ & 20,000 & SG Corporate \& Investment Banking \\
\hline Yantarnoe ZAO & 20,000 & SG Corporate \& Investment Banking \\
\hline TOTAL & $\mathbf{1 6 0 5 , 9 1 0}$ & \\
\hline
\end{tabular}

Source: Dealogic

While forestry and fishing directly rely on natural resources, other agricultural and food industries have both direct and indirect impacts on the environment. The total lending volume of loans into Russia's agriculture, food and forestry segments is comparatively low, due to the smaller size of the average deal. The sector is financed primarily from within the Russian banking sector, specifically by the state-owned Russian Agricultural Bank, and by multilateral development banks. Amongst international private lenders, the French bank Societe Generale has been the most active in this particular segment of the Russian economy.

Table 17. Ten Largest Loans in the Russian Finance Sector (January 2006 - July 2009)

\begin{tabular}{|c|c|c|}
\hline Borrower & $\begin{array}{l}\text { Total Deal Value } \\
\text { (USD million) }\end{array}$ & Mandated Lead Arrangers \\
\hline Sberbank & 1500,000 & $\begin{array}{l}\text { ABN AMRO, Barclays, JP Morgan plc, } \\
\text { Sumitomo Mitsui Banking Corp, BNP Paribas, } \\
\text { Bank of Tokyo-Mitsubishi UFJ Ltd, BayernLB, } \\
\text { Citigroup Inc, DZ Bank, Deutsche Bank, } \\
\text { Dresdner Kleinwort, Erste Bank AG, HSBC, } \\
\text { Mediobanca SpA, Merrill Lynch International, } \\
\text { Mizuho Corporate Bank Ltd, SG Corporate \& } \\
\text { Investment Banking, Sanpaolo IMI SpA, } \\
\text { Unicredit }\end{array}$ \\
\hline VTB Group & 1400,000 & $\begin{array}{l}\text { BNP Paribas, Bank of Tokyo-Mitsubishi UFJ } \\
\text { Ltd, Barclays, BayernLB, Citigroup Inc, } \\
\text { Deutsche Bank, Intesa Sanpaolo Bank Ireland } \\
\text { plc, JP Morgan plc, Mizuho Corporate Bank } \\
\text { Ltd, Sumitomo Mitsui Banking Corp Europe } \\
\text { Ltd }\end{array}$ \\
\hline Sberbank & 1200,000 & 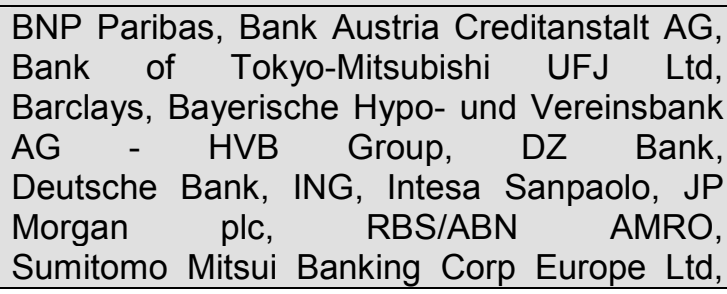 \\
\hline
\end{tabular}




\begin{tabular}{|c|c|c|}
\hline & & WestLB AG, Yapi Kredi Bank Nederland NV \\
\hline $\begin{array}{l}\text { Raiffeisenbank } \\
\text { ZAO }\end{array}$ & 1000,000 & $\begin{array}{l}\text { Bank of Tokyo-Mitsubishi UFJ Ltd, Barclays, } \\
\text { BayernLB, Citigroup Inc, } \\
\text { Deutsche Bank, Intesa Sanpaolo Bank Ireland } \\
\text { plc, Landesbank Baden-Wuerttemberg - } \\
\text { LBBW, Mizuho Corporate Bank Ltd, Unicredit } \\
\text { Group, Wachovia Bank NA, WestL, } \\
\text { DZ Bank AG Deutsche Zentral- } \\
\text { Genossenschaftsbank, } \\
\text { Landesbank Raiffeisen- } \\
\text { Raiffeisen-Landesbank Steiermark } \\
\text { Raiffeisenlandesbank AG, } \\
\text { Raiffeisenlandesbank Niederosterreich-Wien } \\
\text { AG, Raiffeisenlandesbank Oberoesterreich } \\
\text { AG, Raiffeisenlandesbank Vorarlberg, } \\
\text { Raiffeisenverband-Salzburg AG } \\
\end{array}$ \\
\hline Alfa Bank OAO & 900,000 & $\begin{array}{l}\text { Commerzbank AG, HSBC, Natixis, Standard } \\
\text { Chartered Bank, DZ } \\
\text { Emirates Bank International PJSC, } \\
\text { GarantiBank International N NV, } \\
\text { ICICI Bank UK plc, ING, Mashreqbank PSC, } \\
\text { Sumitomo Mitsui Banking Corp, } \\
\text { Mega International Commercial Bank Co Ltd, } \\
\text { Mizuho Corporate Bank Ltd, }\end{array}$ \\
\hline $\begin{array}{l}\text { Bank for Foreign } \\
\text { Trade OAO - } \\
\text { Vneshtorgbank } \\
\text { VTB) }\end{array}$ & 850,000 & Barclays, Deutsche Bank, JP Morgan plc \\
\hline $\begin{array}{l}\text { Vnesheconomba } \\
\text { nk (VEB) }\end{array}$ & 800,000 & $\begin{array}{l}\text { Bank of Tokyo-Mitsubishi UFJ Ltd, Deutsche } \\
\text { Bank, Dresdner Kleinwort, RZB, } \\
\text { BayernLB, Erste Bank AG, HSBC, Mizuho, } \\
\text { Sumitomo Mitsui Banking Corp }\end{array}$ \\
\hline Sberbank & 750,000 & $\begin{array}{l}\text { Bank of Tokyo-Mitsubishi UFJ Ltd, Barclays, } \\
\text { DZ Bank AG, Deutsche Zentral- } \\
\text { Genossenschaftsbank, } \\
\text { Deutsche Bank, ING, JP Morgan plc, } \\
\text { Sumitomo Mitsui Banking Corp }\end{array}$ \\
\hline $\begin{array}{l}\text { Raiffeisen } \\
\text { Zentralbank } \\
\text { Oesterreich AG } \\
\text { (Moscow) }\end{array}$ & 625,000 & $\begin{array}{l}\text { ABN AMRO, Bank of Tokyo-Mitsubishi UFJ } \\
\text { Ltd, Calyon, WestLB, American Express Bank } \\
\text { GmbH, BayernLB, DZ Bank AG Deutsche } \\
\text { Zentral-Genossenschaftsbank, Intesa Bank } \\
\text { Ireland plc, Landesbank Baden-Wuerttemberg } \\
-\quad \quad \text { LBBW, Raiffeisenlandesbank } \\
\text { Oberoesterreich AG, WGZ-Bank } \\
\text { Westdeutsche Genossenschafts-Zentralbank } \\
\text { eG, Wachovia Bank NA }\end{array}$ \\
\hline $\begin{array}{l}\text { Bank for Foreign } \\
\text { Trade OAO - } \\
\text { Vneshtorgbank } \\
\text { (VTB) }\end{array}$ & 600,000 & $\begin{array}{l}\text { Bank of Tokyo-Mitsubishi Ltd, Barclays, ING, } \\
\text { Sumitomo Mitsui Banking Corp, } \\
\text { American Express Bank Ltd, BNP Paribas, } \\
\text { Bank of New York, BayernLB, Wachovia Bank } \\
\text { NA, Deutsche Bank, Dresdner Kleinwort } \\
\text { Wasserstein, Goldman Sachs International, } \\
\text { HSBC, Mizuho Ltd, Natexis Banques } \\
\text { Populaires SA, RZB, Sanpaolo IMI SpA }\end{array}$ \\
\hline TOTAL & 9625,000 & \\
\hline
\end{tabular}

Source: Dealogic.

The majority of financing injected into the Russian financial system via international syndicated loans is eventually channeled through various financial intermediaries into the real economy in the country, 
including environment-intensive sectors. However, the cumulative value of the ten largest deals in the Russian finance sector is significantly lower than the respective figures for sectors such as oil and gas, chemicals and metals, or transport and telecommunications. This data is relatively representative of the trend in the Russian banking sector, as it is primarily state-owned banks and Russian subsidiaries of foreign FIs that raise capital via external loan funding mechanisms. In this instance, Alfa Bank is the only private Russian FI listed amongst the top ten transactions.

\subsection{Loans Provided by Russian Banks: A Sectoral Analysis}

\section{Kamila Ilyumzhinova}

Similar to the overview of the sectoral distribution of international syndicated loans in Russia, the following analysis of lending activities on the part of Russian banks, particularly into the environmentintensive sectors of the Russian economy, has been carried out with the objective of identifying the principal lenders into each industry. The environment-intensive sectors are classified as follows:

- Construction, real estate and project finance;

- Manufacturing (excluding light industry), metallurgy and mining;

- Electricity, including hydro and nuclear power;

- Oil and gas, fuel, coal and chemicals;

- Transport and communications;

- Agriculture, food and forestry; and

- Defense and aircraft industries.

Other Russian industries tapping financial resources from the domestic lenders, e.g. wholesale and retail trade, have not been included into the analysis as their environmental footprint is much less significant.

Separately, Chapter 2.4 also analyzes the 'intangible' lending to Russian FIs by other Russian FIs, which is assessed as environmentally neutral, but may stand for multi-leg channeling of financial resources into the environment-intensive sectors, too.

Data limitations have precluded compilation of a comprehensive rating of Russian banks by the volume of loans to the environment-intensive industries, and the below analysis is limited to overview of 25 top Russian banks based on their IFRS statements. According to the Russian Central Bank's statistics, these 25 banks provided in loans to both corporate and retail customers almost 80 percent $(389,266$ million) of the total domestic lending volume (USD 500.6 million) in 2007 (Table 18). However, it is important to note that this approach results in the following omissions:

- The sample excludes loans provided by the domestic subsidiaries of some important international FIs with a growing presence in Russia such as Raiffeisen International BankHolding AG;

- The sample excludes a number of medium-sized regional banks that often act as key lending institutions in their respective geographical zones, for example the Bank of Khanty-Mansiysk (Khanty-Mansiysk) or Center-Invest Bank (Rostov-on-the-Don);

- As explained in Section 2.4, some limitations were encountered in terms of differing industry classification scales applied by the banks in their IFRS reporting methodologies. 
Table 18. Russia's Top 25 Banks - Lending to Environment-Intensive Industries

\begin{tabular}{|c|c|c|c|c|c|c|c|c|c|}
\hline & \multicolumn{3}{|c|}{$\begin{array}{l}\text { Environment-intensive } \\
\text { lending (USD million) }\end{array}$} & \multicolumn{3}{|c|}{$\begin{array}{l}\text { Environment-intensive } \\
\text { lending (percentage of } \\
\text { the total loans' } \\
\text { portfolio) }\end{array}$} & \multicolumn{2}{|c|}{$\begin{array}{l}\text { Total Lending } \\
\text { (corporate and retail) }\end{array}$} & Portfolic \\
\hline & 1H 2008 & 2007 & 2006 & $1 \mathrm{H} 2008$ & 2007 & 2006 & 1H 2008 & 2007 & 2006 \\
\hline Sberbank & NA & 61562 & 41059 & NA & $37 \%$ & $41 \%$ & NA & 164510 & 100413 \\
\hline VTB & 36238 & 28500 & 14966 & $47 \%$ & $47 \%$ & $49 \%$ & 77611 & 60021 & 30235 \\
\hline Russian Agricultural Bank & NA & 9126 & 4559 & NA & $75 \%$ & $75 \%$ & NA & 12168 & 6074 \\
\hline Gazprombank & 10712 & 8977 & 6723 & $54 \%$ & $53 \%$ & $56 \%$ & 19723 & 16896 & 12054 \\
\hline Alfa Bank & 12529 & 8906 & 6347 & $62 \%$ & $58 \%$ & $65 \%$ & 20210 & 15418 & 9784 \\
\hline VEB Bank & NA & 7508 & 2931 & NA & $83 \%$ & $44 \%$ & NA & 8996 & 6676 \\
\hline Unicreditbank & NA & 6163 & 4018 & NA & $55 \%$ & $64 \%$ & NA & 11131 & 6301 \\
\hline Bank of Moscow & 7284 & 6013 & 4783 & $39 \%$ & $41 \%$ & $49 \%$ & 18686 & 14509 & 9851 \\
\hline Promsvyazbank & 5127 & 3835 & 2218 & $42 \%$ & $44 \%$ & $49 \%$ & 12165 & 8700 & 4518 \\
\hline Rosbank & NA & 3526 & 1807 & NA & $37 \%$ & $30 \%$ & NA & 9556 & 6124 \\
\hline MDM bank & 3942 & 3475 & 3089 & $45 \%$ & $46 \%$ & $47 \%$ & 8843 & 7598 & 6508 \\
\hline Petrocommerce & NA & 3014 & 2156 & NA & $53 \%$ & $50 \%$ & NA & 5685 & 4273 \\
\hline NOMOS & 3901 & 2908 & 1656 & $52 \%$ & $51 \%$ & $56 \%$ & 7574 & 5655 & 2974 \\
\hline Uralsib Bank & NA & 2744 & 1915 & NA & $28 \%$ & $30 \%$ & NA & 9753 & 6353 \\
\hline International Industrial Bank & NA & 2157 & 1631 & NA & $50 \%$ & $47 \%$ & NA & 4346 & 3451 \\
\hline AK BARS Bank & NA & 1896 & 1223 & NA & $39 \%$ & $45 \%$ & NA & 4880 & 2697 \\
\hline Zenit & 1913 & 1541 & 966 & $39 \%$ & $36 \%$ & $41 \%$ & 4891 & 4238 & 2362 \\
\hline Transcreditbank & 1982 & 1386 & 1024 & $38 \%$ & $37 \%$ & $46 \%$ & 5228 & 3777 & 2235 \\
\hline Vozrozhdenie & NA & 1323 & 954 & NA & $40 \%$ & $46 \%$ & NA & 3298 & 2065 \\
\hline Absolut Bank & NA & 1034 & 693 & NA & $27 \%$ & $41 \%$ & NA & 3800 & 1673 \\
\hline $\begin{array}{l}\text { Moscow Bank for Reconstruction } \\
\text { and Development }\end{array}$ & NA & 844 & 516 & NA & $29 \%$ & $37 \%$ & NA & 2945 & 1385 \\
\hline Soyuz Bank & NA & 839 & 543 & NA & $40 \%$ & $42 \%$ & NA & 2105 & 1282 \\
\hline URSA & 663 & 797 & 559 & $12 \%$ & $15 \%$ & $21 \%$ & 5494 & 5418 & 2671 \\
\hline Globex & NA & 624 & 589 & NA & $23 \%$ & $34 \%$ & NA & 2673 & 1734 \\
\hline National Reserve Bank & NA & 391 & 178 & NA & $33 \%$ & $25 \%$ & NA & 1188 & 710 \\
\hline TOTALS (USD million) & 84292 & 169089 & 107101 & $47 \%$ & $43 \%$ & $46 \%$ & 180424 & 389266 & 234402 \\
\hline
\end{tabular}

Source: Banks' IFRS financial statements.

Our research suggests that lending into environment-intensive sectors constitutes an average of $37-43$ percent of the total loans portfolio of the banks included in the analysis. Importantly from the methodological viewpoint, the total loans portfolio also includes retail activities, which often comprise as much as $40-45$ percent of the activities of a number of Russian bank; for example, Transcredit Bank has traditionally serviced the majority of employees of the Russian Railways).

Based on the analysis of the data for the top 25 Russian banks, it is possible to conclude the following:

- Russia's large state-owned banks (VEB, VTB, Sberbank, Russian Agricultural Bank and Gazprombank) contribute more than 50 percent (66 percent in 2006, 67 percent in 2007, and 54 percent in $1 \mathrm{H} 2008$ ) of the total lending into the environment-intensive industries in Russia;

- For each of the 25 banks, the proportions of lending to individual industries have mainly remained almost unchanged in $2006-1 \mathrm{H} 2008$, with the exception of VEB that in 2007 lent a record amount of USD 4.4 billion into the oil and gas industry, driving the organisation's percentage of loans into the respective sector from 9 percent in 2006 to 49 percent in 2007, and the bank's overall share of lending into environment-intensive industries from a relatively modest 44 percent in 2006 to 83 percent in 2007. 
Figure 5. Domestic Lenders to the Russian Construction, Real Estate and Project Finance Sector in 2007

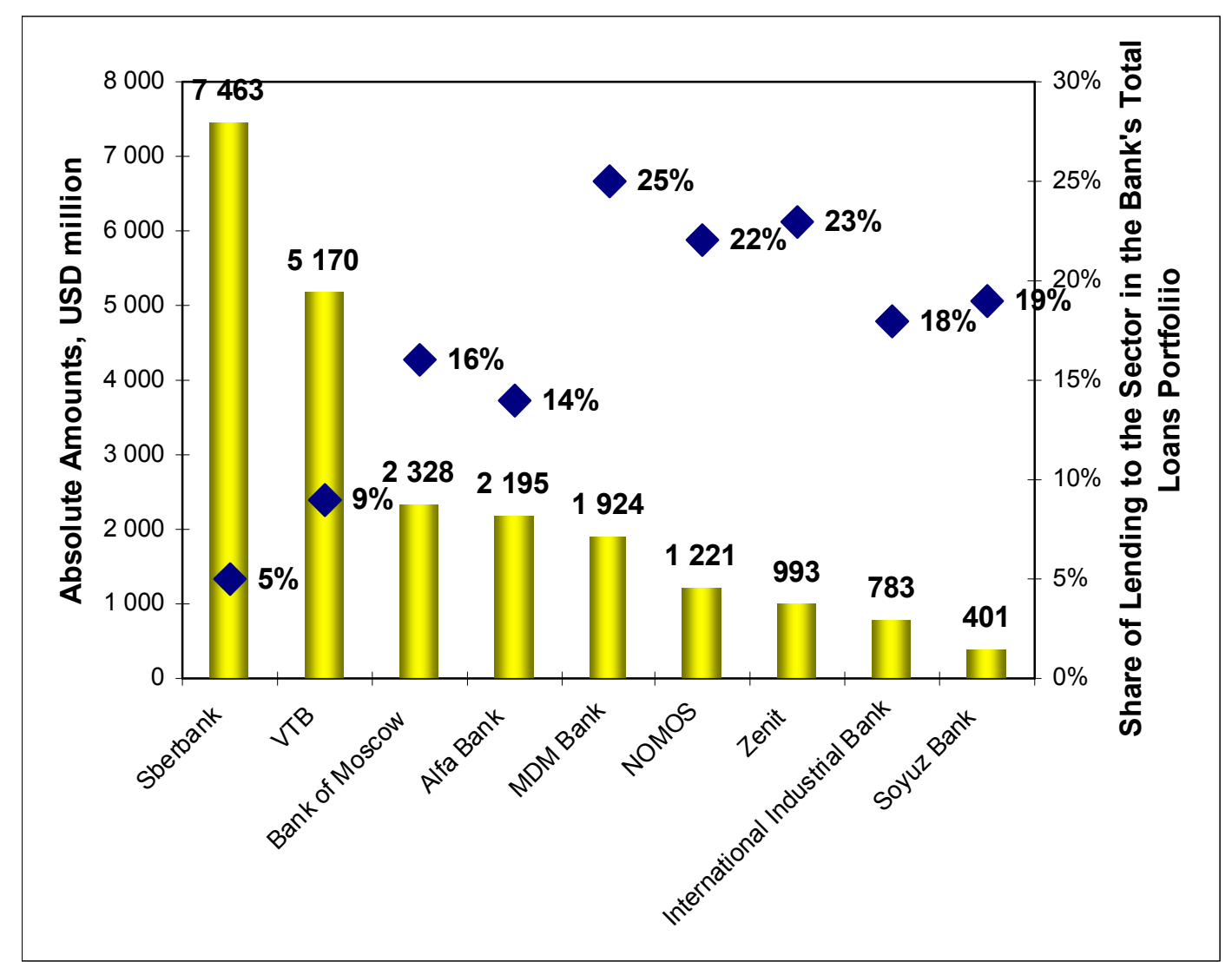

Source: Banks’ IFRS financial statements.

The property boom which took place in Russia prior to the 2008/9 financial crises was primarily fuelled by domestic lending, with large-scale loans being extended by Russian state-owned banks. Sberbank lent the highest amount into Russia's real estate industry; however, due to the large size of the organisation's total portfolio, these loans constituted only a relatively small proportion of its total lending. Overall, the Russian real estate sector is diversified in terms of its funding sources, as loans from the top five lenders constituted approximately 40 percent of total lending in the sector in both 2007 and 2006, with all 25 sample institutions having some exposure to this particular sector.

Being the principal provider of finance for new construction in Russia, domestic FIs have therefore a particularly important role in raising the energy efficiency of this industry, which, due to the Russian real estate sector's size and current high energy consumption levels may entail tremendous improvements in the country's overall energy efficiency and reduction of greenhouse gases emissions. The model to follow in this respect will be the energy efficiency programmes launched in Russia by IFC and EBRD (see section 2.3). 
Figure 6. Domestic Lenders to the Russian Manufacturing (Excluding Light Industry), Metallurgy and Mining Sector in 2007

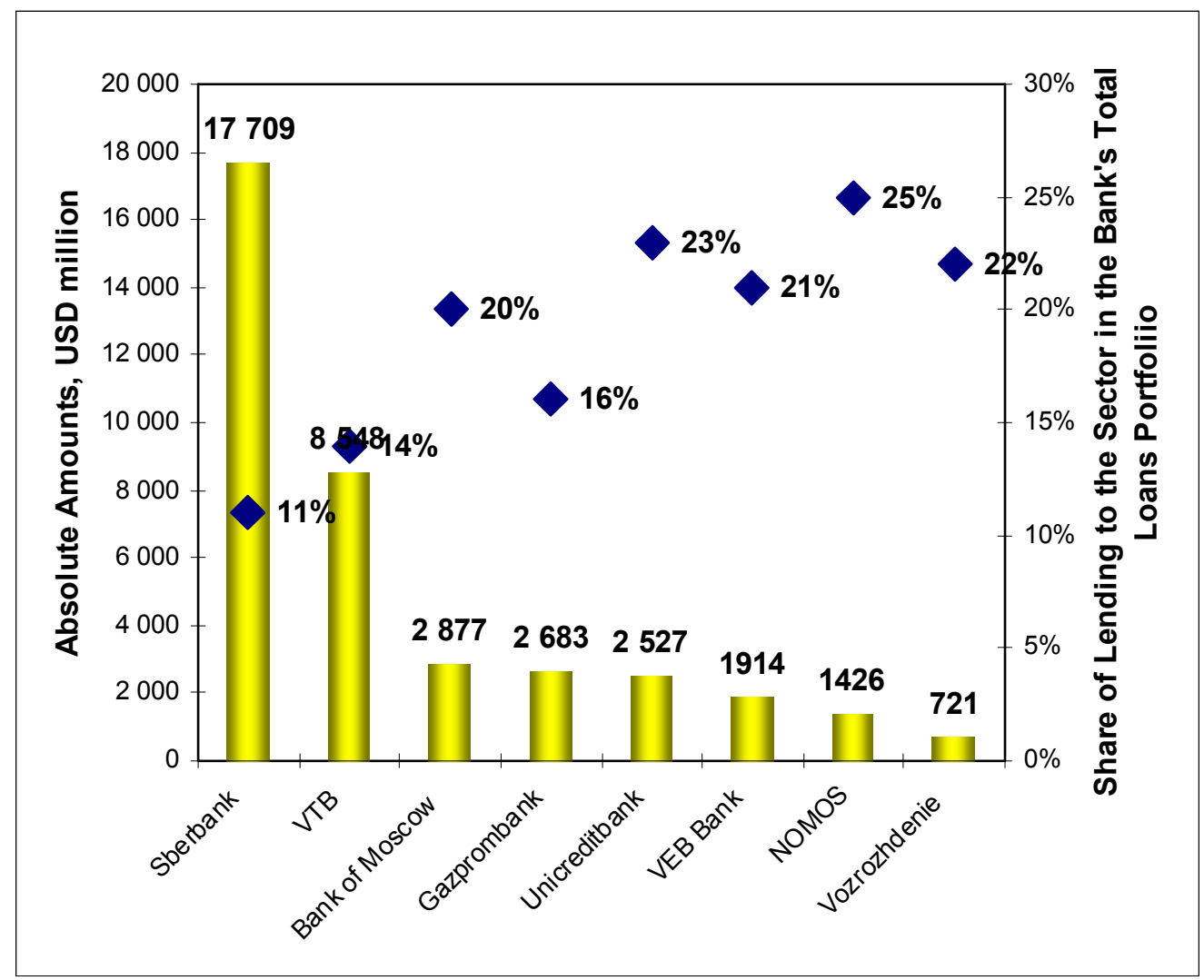

Source: Banks’ IFRS financial statements.

As explained in Section 2.4, Russia's manufacturing, metallurgy and mining sector is heavily dependent on external capital markets. Russian FIs have only limited ability to extend financing into these industries, with Sberbank, VTB, Gazprombank and Bank of Moscow having the largest sectoral exposure. 
Figure 7. Domestic Lenders to the Russian Electricity Sector (Including Hydro and Nuclear Power) in 2007

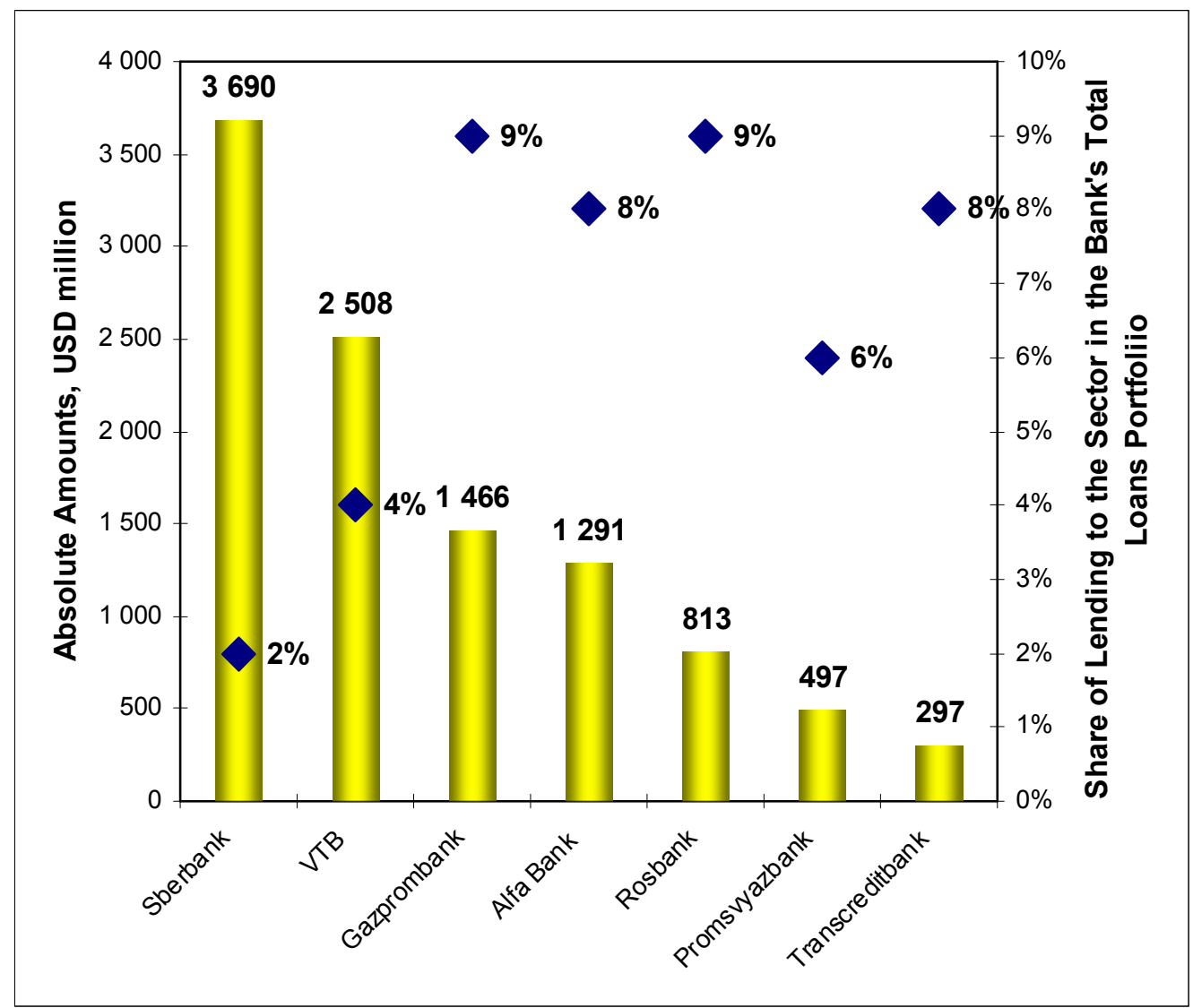

Source: Banks’ IFRS financial statements.

Russian FIs account for a considerable proportion of finance raised by the Russian electric energy sector, but only ten Russian FIs out of the top 25 hold any exposure in it. Similarly to the construction industry, modernisation of the Russian electricity generation and transmission capacities plays a crucial role in improving the country's overall energy efficiency. Another environmental controversy for the Russian FIs lending to this sector concerns large hydropower and nuclear energy plants. While those two types of power plants are believed to be carbon-neutral, decisions on their construction and funding must be preceded by thorough environmental impact assessment and consultations with stakeholders. 
Figure 8. Domestic Lenders to the Russian Oil, Gas, Coal, Fuel and Chemical Sector in 2007

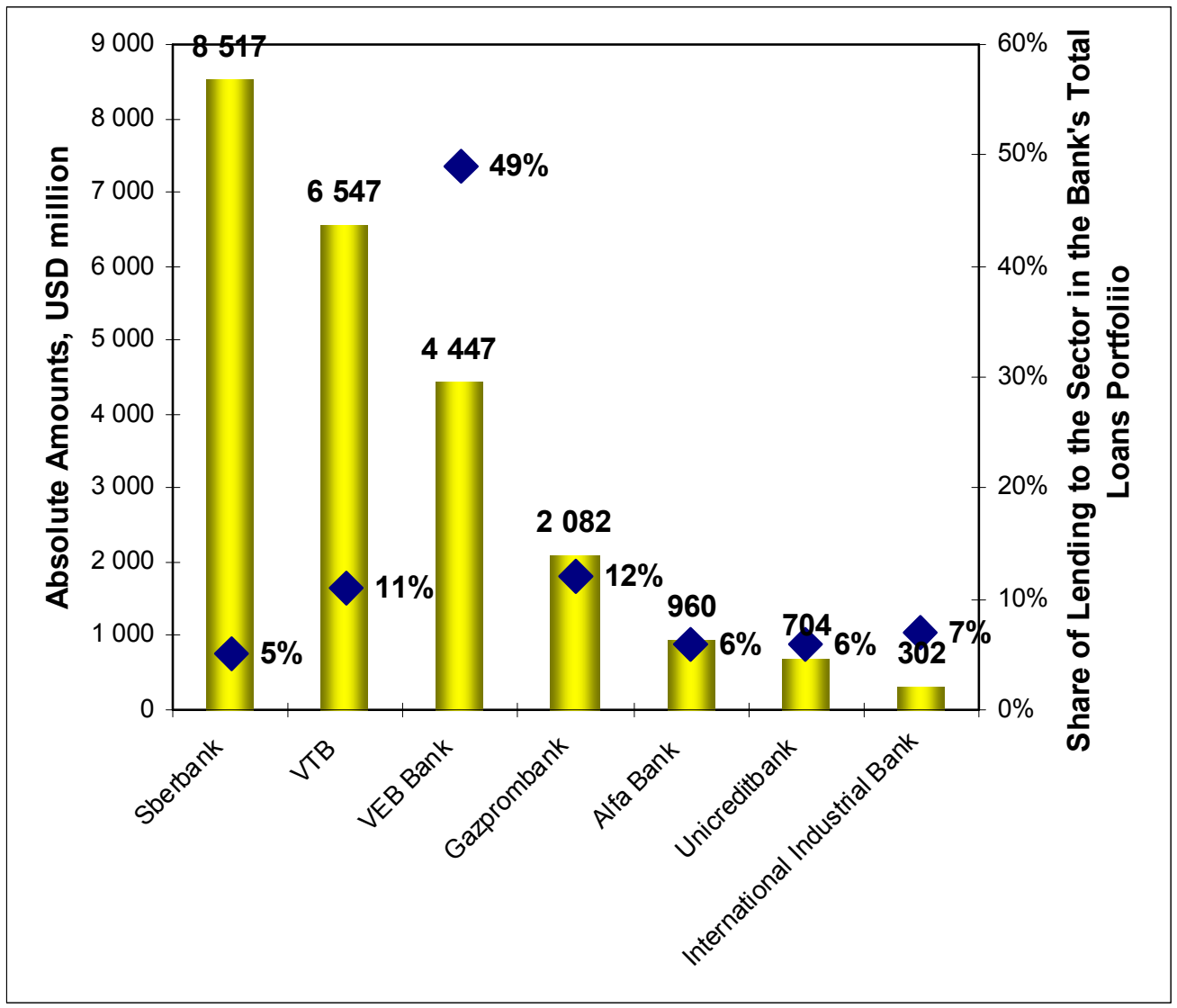

Source: Banks’ IFRS financial statements.

As mentioned in Section 2.4, very few Russian FIs possess sufficient funds for extensive lending into the capital-intensive oil and gas sector, which is therefore heavily dependent on international capital markets. Of the finance raised for the sector domestically in 2006 - 2008, about $80-90$ percent was provided by the four state-owned banks: Sberbank, VTB, VEB and Gazprombank. In particular, in 2007 VEB lent a record amount of USD 4.4 billion into the oil and gas industry, driving the organisation's percentage of loans into the respective sector from 9 percent in 2006 to 49 percent in 2007. From the information available, it would appear that the reason for this spike in lending activity into the oil and gas sector in 2007, was the fact that VEB granted a mega-loan to a state-associated company in the form of pre-export financing. 
Figure 9. Domestic Lenders to the Russian Transport and Communications Sector in 2007

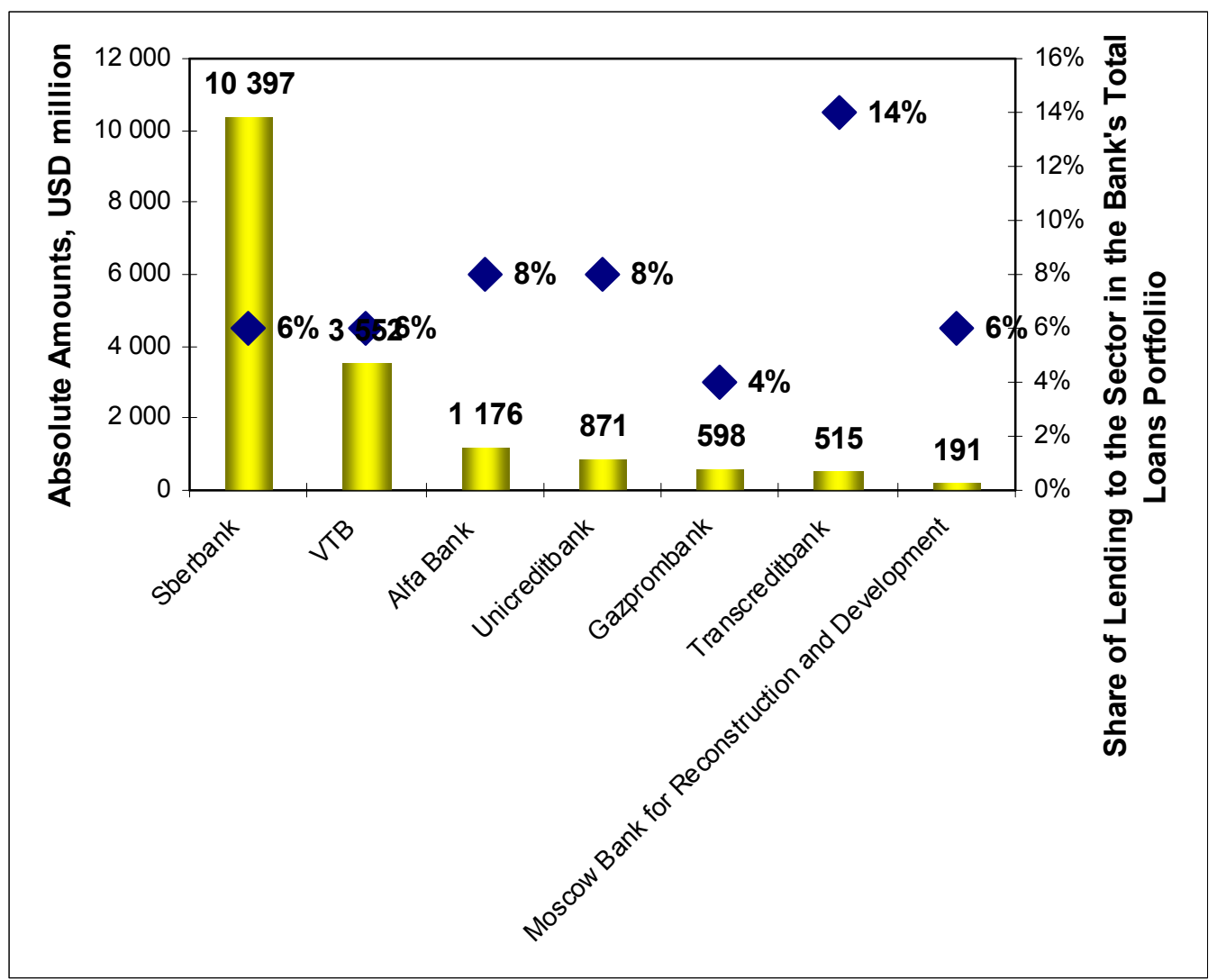

Source: Banks’ IFRS financial statements.

Sberbank and VTB are the two key domestic providers of finance in the Russian transport and communications sector. Transcreditbank, which is owned by Russian Railways, also plays a significant role in the sector, offering various banking services to the mother company. A similar approach, though on a much smaller scale, is employed by Russia's largest shipping company Sovcomflot that owns Sovcombank. 


\section{Figure 10. Domestic Lenders to the Russian Agricultural Sector (Including Food, Forestry and} Fishery) in 2007

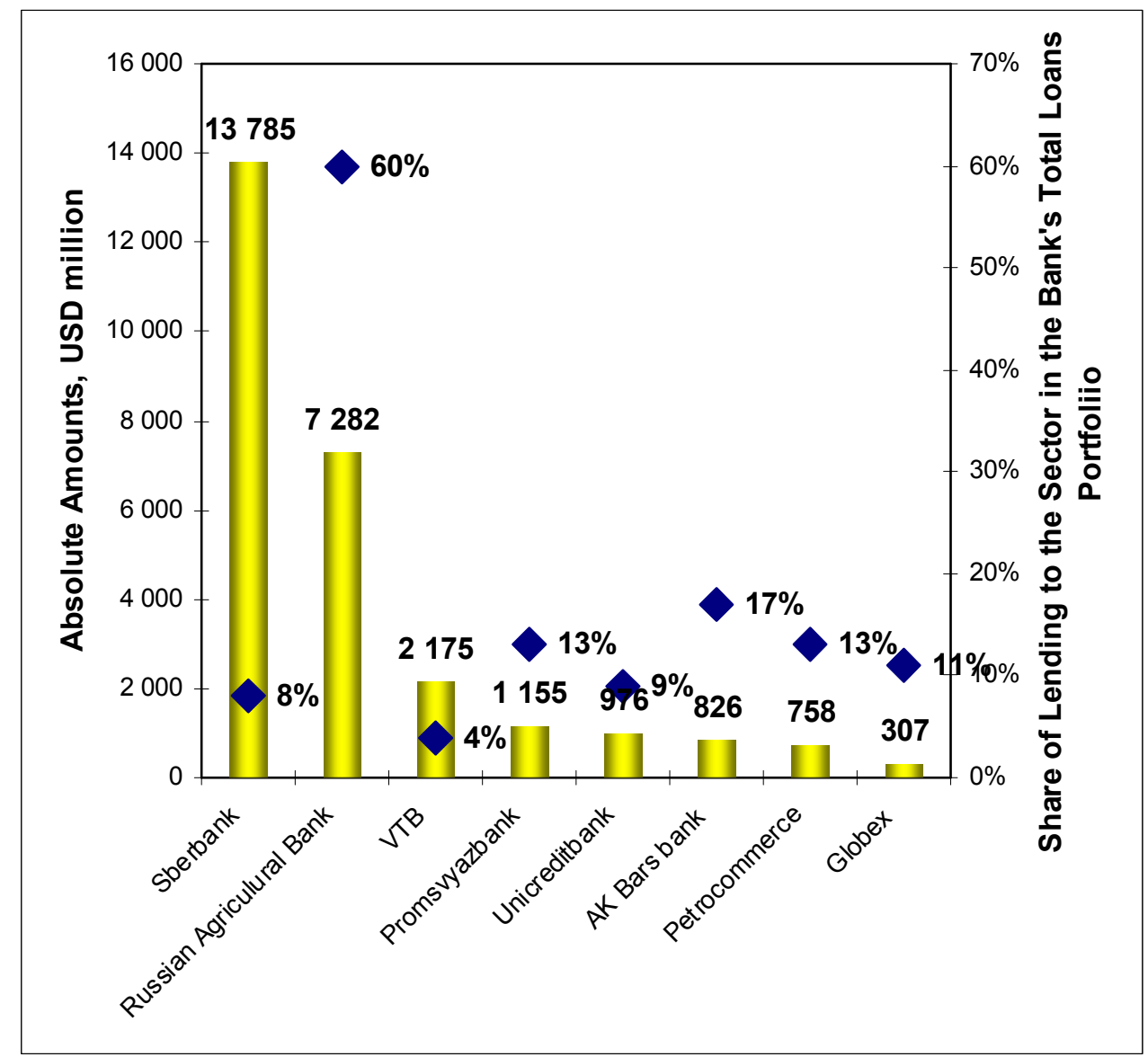

Source: Banks' IFRS financial statements.

Domestic banks, particularly Sberbank and the Russian Agricultural Bank (Rosselkhozbank) are by far principle providers of funds for the Russian agriculture, which has a very limited reliance on external capital markets. A leading position occupied by the Russian Agricultural Bank in the sector is consistent with its official status as the Russian government's principal agent in providing financial services to the country's agribusiness sector. The Bank has been identified as the primary stakeholder in the implementation of the Federal Programme on Agribusiness Development, 2008-2012. It has also continued to extend its loans book in spite of the global financial crisis, having reported a total loan volume of approximately USD 15 billion as of 1 April 2009. 


\section{Defense}

Figure 11. Domestic Lenders to the Russian Defense Sector in 2007

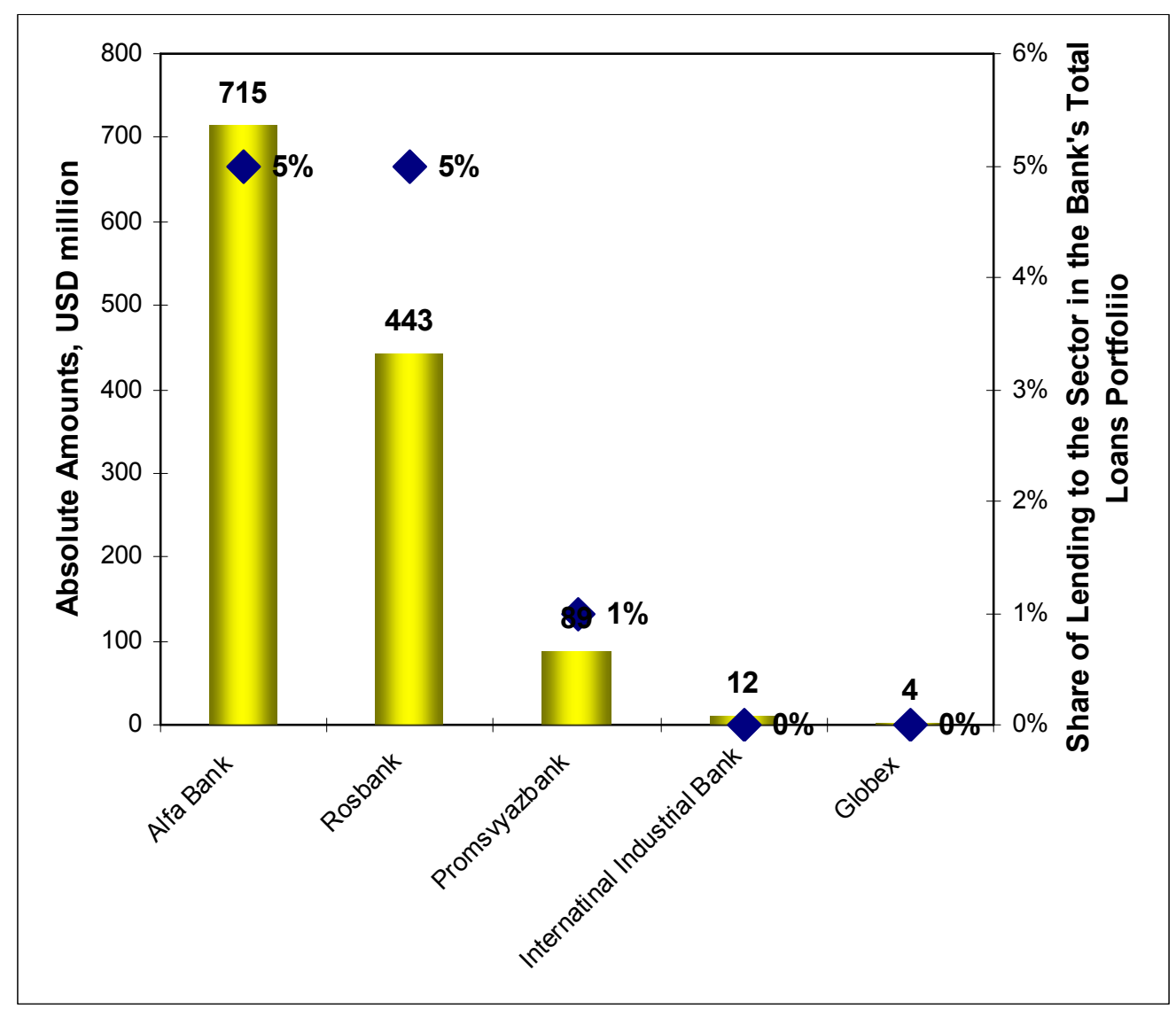

Source: Banks’ IFRS financial statements.

Only five out of the 25 top banks in Russia have reported their exposure to the defense sector, with the total lending volume into this particular industry being significantly lower than into other sectors of the real economy. It is however expected that this figure might be revised upwards to a significant degree if the financing extended by VEB into the defense segment is reported as a separate item, rather than being included in the manufacturing sector.

\section{"Intangible" Lending}

As has been suggested by several ratings institutions, the total cashflow volume "trickling down" to real economy sectors is an intangible measure, and is difficult to quantify with any degree of accuracy. This is particularly the case in Russia, where large banks often extend a significant proportion of their loans portfolios to smaller financial institutions, thereby injecting liquidity into the financial system itself, rather than into the real economy. In Russia the "intangible lending" by 25 top banks amounted to USD 20 billion in 2006 and USD 29 billion in 2007, which is comparable to the lending volume by the same sample of banks to the entire agricultural sector in Russia (USD 19 billion in 2006 and USD 31 billion in 2007). 
Figure 12. 'Intangible' Lending in Russia: Domestic Lenders to the Russian Financial Sector in 2007

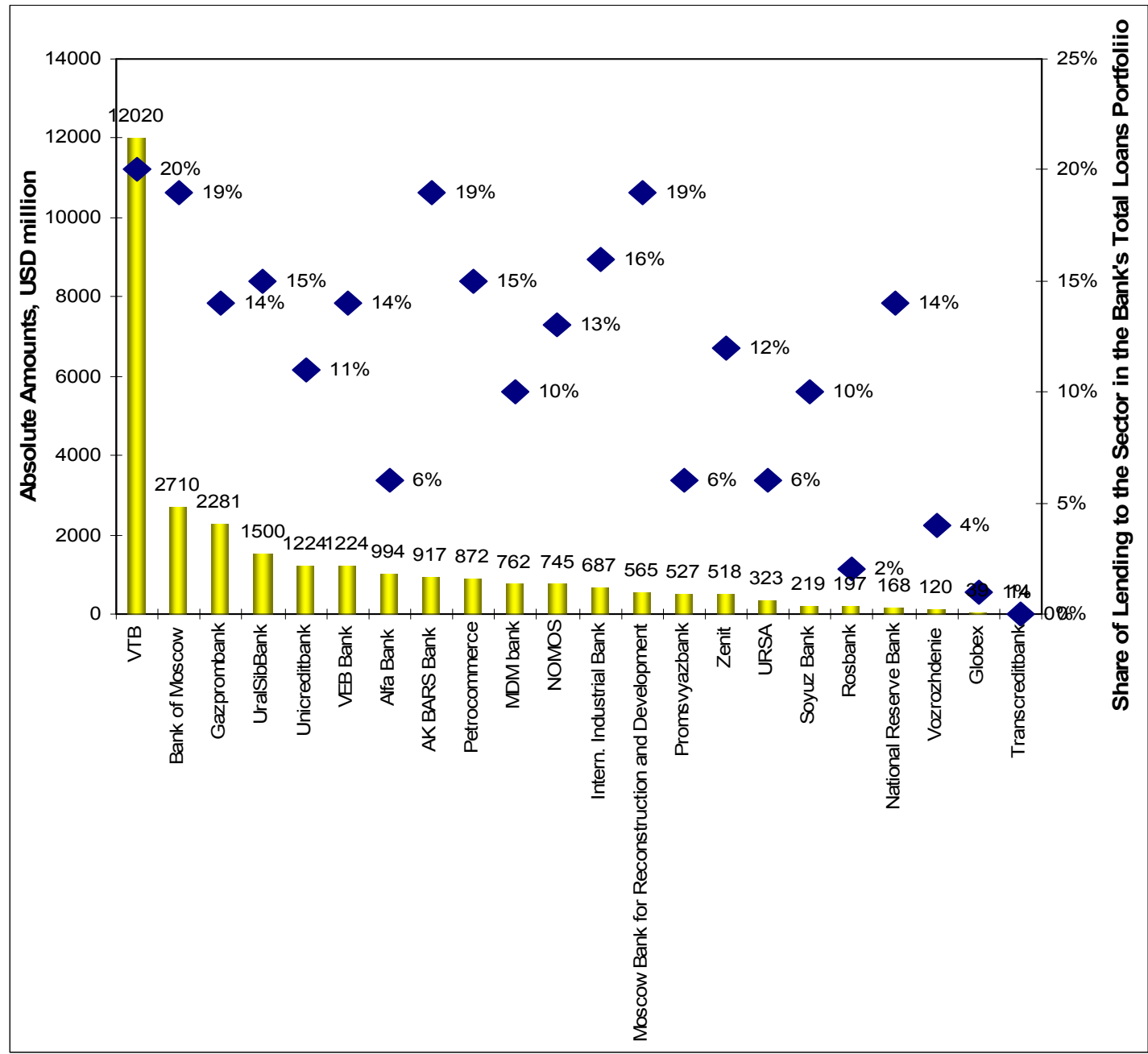

Source: Banks' IFRS financial statements.

Traditionally, a state-owned financial institution - VTB Bank - has been primarily responsible for injecting liquidity into the Russian financial system. By contrast, other two large state-owned banks Sberbank and the Russian Agricultural Bank - completely abstain from "intangible” lending.

The total loans volume extended into the Russian financial industry have significantly increased in 2008 and 2009, as the Russian government was forced by the credit crisis to support the national financial system via two intermediaries, namely not only VTB, but also the newly established Development Bank of Russia - VEB. In the circumstances of the credit crunch, these two institutions provide financing to a large number of Russian corporate borrowers and FIs in order to enable them to repay their foreign debt obligations.

Due to the increased proportion of lending into the Russian financial sector in $2008-2009$, Russian banks have significantly reduced their overall involvement with the environment-intensive industries. It has been reported elsewhere that the liquidity crisis has forced the postponement or cancellation of many projects with potentially damaging environmental impacts. At the same time, however, the lack of liquidity might also impact negatively on the implementation of environmentally beneficial projects, for example those in the renewable energy sector. 


\section{CHAPTER 3. TOWARD RESPONSIBLE FINANCE IN RUSSIA}

\subsection{Overview of the Existing Environmental Assessment Procedures in Russia}

\section{Renat Perelet and Ekaterina Khmeleva}

While international frameworks of FIs' environmental and social responsibility described in Chapter 1 are purely voluntary measures, they are, among other factors, a reflection of letter and spirit of the laws adopted in the countries of origin of the signatory FIs. For example, the EBRD environmental and social responsibility standards are closely intertwined with the corresponding requirements of the EU legislation, with the objective of extending most of the EU environmental and social responsibility requirements to projects financed by the EBRD outside the EU in cases where the EU legislation is more stringent than that of the state hosting the project. The same generalization applies to the OECD 'Common Approaches' to export credit agencies.

Likewise, any developments in environmental and social responsibility of Russian FIs are connected with relevant legal requirements in Russia as much as they are driven by business realities. Therefore this section gives a brief overview of the state of Russia' environmental legislation applicable to investment projects.

The process of Environmental Impact Assessment (EIA) is a requirement of the evaluation and decisionmaking process for any industrial or commercial project in Russia. Article 32 of the Federal Law "On Environmental Protection" states that an EIA should be carried out on any planned activity that may have a negative impact on the environment. The results of this EIA should then be submitted to a State Environmental (Expertise) Review (SER) or a State (Expertise) Review (SR) depending on the type of the project under consideration.

According to Federal Law "On Environmental (Expertise) Review" of 1995, a positive conclusion on the part of an expert commission approved by the relevant state agency, is a mandatory condition for the realisation of any project related to a particular area of expertise. Among these areas of expertise are activities to be implemented on Russia's continental shelf, within an Exclusive Economic Zone, within Protected Natural Areas, or related to the disposal of hazardous waste. In this regard, the objective of a SER is an evaluation of the compliance of planned activities with environmental standards and regulations.

All other activities and projects are subject to a State Review, according to the regulations of the City Planning Code. This regulation covers all planned activities, projects and construction, even those not located within cities and towns. Environmental impact is only one of a number of issues covered by such a Review; which implies that environmental considerations are sometimes not accorded the attention and level of detailed evaluation that they require. In particular, EIA under SR does not require stakeholders engagement and public consultations.

Thus EIA and SER/SR are two subsequent stages of pre-project and design analysis, with different mechanisms that do not apply at the stage of analysis of intent (feasibility study) and monitoring of the project's implementation. In general, the process of approval for an investment project, and its correlation with environmental evaluation, takes place according to the algorithm described in Table 19. 
Table 19. Environmental Decision-Making throughout Investment Project Life Cycle

\begin{tabular}{|c|c|c|}
\hline Investment Project Stages & \multicolumn{2}{|c|}{ Environmental Decision-Making Stages } \\
\hline \multirow[t]{7}{*}{ 1. Feasibility study } & \multicolumn{2}{|l|}{ 1.1. Investment and project idea } \\
\hline & \multicolumn{2}{|l|}{ 1.2. Preliminary impact assessment } \\
\hline & \multicolumn{2}{|c|}{ 1.3. Declaration of Intent submitted to relevant authorities } \\
\hline & \multicolumn{2}{|c|}{ 1.4. Preliminary agreement of authorities with proposed project } \\
\hline & \multicolumn{2}{|c|}{ 1.5. Public consultations, consultation with relevant officials and other parties } \\
\hline & \multicolumn{2}{|c|}{ 1.6. Decision regarding feasibility and acceptability of project / activity } \\
\hline & \multicolumn{2}{|c|}{ 1.7. Development of Terms of Reference for EIA } \\
\hline \multirow{3}{*}{$\begin{array}{l}\text { 2. Environmental Impact } \\
\text { Assessment }\end{array}$} & \multicolumn{2}{|c|}{ 2.1. Engineering and EIA work performance } \\
\hline & \multicolumn{2}{|c|}{$\begin{array}{l}\text { 2.2. Confirmation of planned activity and location; public consultation on } \\
\text { preliminary EIA }\end{array}$} \\
\hline & \multicolumn{2}{|c|}{ 2.3. Preparation of preliminary EIA documentation } \\
\hline \multirow{3}{*}{$\begin{array}{l}\text { 3. Development and } \\
\text { adoption of project } \\
\text { documentation }\end{array}$} & \multicolumn{2}{|c|}{$\begin{array}{l}\text { 3.1. Drafting of final EIA documentation, taking into account technical features } \\
\text { and environmental protection measures of project }\end{array}$} \\
\hline & \multicolumn{2}{|c|}{ 3.2. State reviews of project documentation (including EIA documentation) } \\
\hline & $\begin{array}{l}\text { SER - projects included in the } \\
\text { list of subjects / sectors where it } \\
\text { is required }\end{array}$ & $\begin{array}{l}\mathrm{SR} \text { - environmental element of a general } \\
\text { review, in cases where SER is not required }\end{array}$ \\
\hline \multirow[t]{2}{*}{$\begin{array}{l}\text { 4. Project / activity } \\
\text { implementation }\end{array}$} & \multicolumn{2}{|c|}{$\begin{array}{l}\text { 4.1. Implementation / construction of project, including environmental } \\
\text { protection measures }\end{array}$} \\
\hline & \multicolumn{2}{|c|}{$\begin{array}{l}\text { 4.2. Environmental monitoring and control during construction, commissioning } \\
\text { and operation }\end{array}$} \\
\hline
\end{tabular}

Source: Environmental Impact Assessment and Environmental Review. Russian-German Methodology Handbook. / Оценка воздействия на окружающую среду и экологическая экспертиза. Российско-германское методологическое пособие. Irkutsk-Berlin-Bonn, 2008. P. 18.

According to the Russian environmental legislation, Stage 4 described in Table 19, namely the project or activity implementation, is not included in the EIA/SER/SR process. Environmental control/monitoring is considered a separate process, independent of EIA/SER/SR and regulated by specific acts and regulations.

In general, the Russian legal framework for environmental assessment is relatively well-developed, but is considerably less integrated with regulations of business activities in other spheres (taxation, licensing, etc) than, for example, in the EU. Table 20 presents a comparative analysis of Russian environmental legislation and internationally recognised frameworks of FIs' environmental and social responsibility. 
Table 20. Comparative Analysis of Russian Environmental Legislation and IFC/EBRD/Equator Principles Frameworks of Environmental and Social Responsibility

\begin{tabular}{|c|c|c|}
\hline Area of Applicability & Russian Legislation & $\begin{array}{l}\text { IFC/EBRD/Equator Principles } \\
\text { Frameworks of Environmental and } \\
\text { Social Responsibility }\end{array}$ \\
\hline $\begin{array}{l}\text { Variance of } \\
\text { Environmental } \\
\text { Decision-Making } \\
\text { Procedures across } \\
\text { Different Investment } \\
\text { Projects }\end{array}$ & $\begin{array}{l}\text { All investment projects implemented } \\
\text { on Russia's continental shelf, within } \\
\text { an Exclusive Economic Zone, within } \\
\text { Protected Natural Areas, or related } \\
\text { to the disposal of hazardous waste } \\
\text { are subject to a State Environmental } \\
\text { Review, including a detailed EIA } \\
\text { procedure. All other projects are } \\
\text { subject to a State Review inclusive } \\
\text { of a 'light' version of EIA. }\end{array}$ & $\begin{array}{l}\text { All investment projects are subject to } \\
\text { an Environmental Assessment, } \\
\text { whereby they are classified into A, B, } \\
\text { and C categories depending on the } \\
\text { degree of their potential } \\
\text { environmental impact. All A Category } \\
\text { and some B Category projects require } \\
\text { EIA, containing development of an } \\
\text { Environmental Management (or } \\
\text { Action) Plan. }\end{array}$ \\
\hline $\begin{array}{l}\text { Environmental } \\
\text { Assessment and the } \\
\text { Investment Project's } \\
\text { Lifespan }\end{array}$ & $\begin{array}{l}\text { EIA and SER/SR are two } \\
\text { subsequent procedures applied at the } \\
\text { stage of pre-project and design } \\
\text { analysis. They come after and do not } \\
\text { apply to the stage of analysis of } \\
\text { intent (feasibility study). In a similar } \\
\text { manner, these two procedures do not } \\
\text { have mechanisms extending to the } \\
\text { later stages of project } \\
\text { implementation. Environmental } \\
\text { control and monitoring is considered } \\
\text { a separate process, regulated by } \\
\text { specific acts and regulations. The } \\
\text { SER/SR process assesses the } \\
\text { conformity of already developed } \\
\text { solutions with environmental } \\
\text { legislation and requirements. }\end{array}$ & $\begin{array}{l}\text { The process of completing an EIA is a } \\
\text { single continuous one through the } \\
\text { entire investment project's lifecycle, } \\
\text { namely the stages of feasibility study, } \\
\text { design, review and implementation. } \\
\text { EIA manifests "a preventive } \\
\text { environmental policy", with the } \\
\text { purpose of identifying project gaps } \\
\text { and taking actions to improve } \\
\text { environmental characteristics, both } \\
\text { before and during the project } \\
\text { implementation. }\end{array}$ \\
\hline $\begin{array}{l}\text { Opportunities for } \\
\text { Stakeholders } \\
\text { Engagement }\end{array}$ & $\begin{array}{l}\text { Opportunities for stakeholders } \\
\text { involvement into the decision- } \\
\text { making process are limited to the } \\
\text { EIA procedure under SER only. }\end{array}$ & $\begin{array}{l}\text { The process provides for active public } \\
\text { participation at all stages of } \\
\text { assessment and decision-making } \\
\text { regarding the project approval and } \\
\text { implementation, public } \\
\text { communication regarding the } \\
\text { assessment process and results, } \\
\text { consultation with relevant } \\
\text { stakeholders, and publication of the } \\
\text { outcomes of the EIA process. }\end{array}$ \\
\hline
\end{tabular}

Source: WWF-Russia analysis.

As evidenced by the experience of foreign FIs in Russia, Russian environmental legislation does not prevent them from implementing international environmental assessment procedures, but rather provides complementarities. Therefore the domestic legislation is neutral in terms of the opportunities for Russian FIs to integrate internationally recognised mechanisms of environmental and social responsibility. 
Usually, the cost of implementing environmental assessment procedures according to both domestic (as required by Russian legislation) and international (as required by foreign FIs as providers of finance to investment projects) standards is incurred on borrowers, i.e. Russian companies. Therefore, harmonisation of the Russian environmental assessment procedures with international FIs' requirements will help the Russian business to avoid financial and time costs of going through two similar processes. Further, such harmonisation will bring about economies of scale for Russian businesses, including banks, undertaking investment projects abroad, under international environmental assessment regime.

\subsection{Recommendations to the Russian Government}

\section{Evgeny Shvarts, Ivetta Gerasimchuk, Kamila Ilyumzhinova and Jürgen Lottmann}

Background. In terms of the subject matter of this study, the integration of internationally-recognised environmental and social responsibility practices in the Russian financial sector appears to be a question of "when" rather than "if", particularly in the context of Russia's pending accession to the Organisation for Economic Cooperation and Development (OECD).

Meanwhile, in the light of the 2008/9 global economic crisis, the role of the Russian government in integration responsibility considerations in the domestic financial sector is certain to increase significantly, as the government has markedly increased its level of direct participation in the country's economy. Furthermore, the government continues to play a very influential regulatory role in the Russian financial sector. As a result, the crisis might be seen as a window of opportunity for the Russian authorities to follow the global cutting-edge economic policies, and enhance the international competitiveness of the national economy through the implementation of appropriate ESG regulations and practices.

Many governments throughout the world have chosen to attempt to shield their economies from the worst effects of the crisis, and to begin the process of recovery, by direct investment of state funds into strategic industries. Russia is no exception in this respect, but whereas in many other countries, procedures relating to environmental impact assessments (EIAs) for new projects, as well as to other 'green' regulations and economic instruments, might already be in place to screen the targets of stimulus packages, Russia runs the risk of being unable to capitalise on certain attractive investment opportunities (such as those to be found in the area of renewable energy, for example), due to a lack of relevant legislation and enforcement.

Certain countries appear to have exhibited significant levels of initiative and thought leadership, in incorporating considerably 'green' components into their economic stimulus packages. These range from 33 percent of total expenditure in China's 'New Deal' of 9 November 2008, to 12 percent of US expenditure under the American Recovery and Reinvestment Act (ARRA) of 17 February 2009 (see Table 21 for more details). According to estimates made by the Center for American Progress (CAP), an investment of USD 100 billion in clean energy and efficiency would result in 2 million new jobs, whereas an investment of the same magnitude in conventional forms of energy would create only approximately 540,000 jobs. ${ }^{49}$

The Russian authorities have also set ambitious 'green' goals, including the following:

- Raising energy efficiency in the Russian economy by 40 percent by 2020 , as formulated in President Dmitry Medvedev's Decree of 4 June 2008 On Measures to make the Russian Economy More Energy and Environment Efficient, and

\footnotetext{
${ }^{49}$ Deutsche Bank (2008).'Economic Stimulus: The Case for 'Green' Infrastructure, Energy Security and 'Green' Jobs.' Deutsche Bank. P. 4. http://www.dbadvisors.com/deam/stat/globalResearch/1113 GreenEconomicStimulus.pdf
} 
- Increasing the share of energy generation from renewable sources, excluding hydroelectricity, to 4.5 per cent of Russia's total generation capacity by 2020 , as outlined in Main Directions of the State Policy in the Sphere of Raising Energy Efficiency Based on Renewable Energy Sources for the Period until 2020 signed by Chair of the Government Vladimir Putin on 20 January 2009.

In terms of achieving these targets, a significant degree of responsibility rests with Russia's various federal, regional, and municipal authorities, as well as with economic actors, including FIs, in order to ensure that meaningful measures in this regard are incorporated into the activities of the Russian business sector.

Proposed measures. WWF would propose that the following measures (amongst others) be implemented by the Russian government:

- The classification of environmental and social risks into a separate category in the Russian Central Bank's methodologies that will enable Russian banks to monitor environmental and social issues consistently and systematically assess and manage these risks;

- The development and enforcement of established procedures regarding environmental impact assessments (EIAs), that represent a revision of those applicable in Russia prior to 2007, and that correspond with international practices (such as those applied by OECD governments and leading multilateral and regional development banks including the World Bank, IFC, EBRD, Asian Development Bank etc). The role of these revised EIA procedures is to provide an effective instrument for protecting the interests of private businesses and individuals in circumstances where these interests might be negatively impacted due to environmental damage caused by the activities of other actors;

- The provision of state funds, including stimulus financing, for industrial projects only on condition of their compliance with the proposed EIA requirements described above;

- The creation of a state-owned 'green' venture fund that will act as an innovation fund to support the achievement of the energy efficiency and renewable energy targets mentioned above;

- Commencement of 'green' public procurement at various government levels and at state-owned companies, including banks, to support domestic producers of 'green' goods and services and their solvency as bank clients;

- Prioritisation of 'green' projects for receipt of state stimulus funds, for example by means of preferential loan structures created by Russian state-owned banks;

- The inclusion of representatives of the Ministry of Natural Resources and Ecology on the Boards of Directors of the major Russian state-owned banks that serve as conduits for stimulus funds (namely the Bank for Development and Foreign Economic Affairs (VEB), VTB, Sberbank and Gazprombank);

- The clear articulation of messages regarding the importance of incorporating environmental and social aspects into internal processes and financing decisions, at the level of core business and policy, to the major Russian state-owned banks (VEB, Sberbank, VTB, Russian Agricultural Bank, Gazprombank). In this regard, the social and environmental guidelines of leading multilateral and regional development banks, as well as those of relevant national development banks, both within and outside the OECD, can serve as banking industry benchmarks that can be modified to take into account prevailing economic conditions in Russia;

- The creation of public consultation councils to the Boards of Directors of the major Russian state-owned banks that serve as conduits for stimulus funds (VEB, VTB, Sberbank, Gazprombank), with the objective of discussing the social and environmental policies applied by 
these banks. These consultation councils should constitute representatives from academia, civil society, environmental NGOs, the international banking industry etc.

Table 21. Global Green Stimulus and Green Investments as of 1 July 2009

\begin{tabular}{|c|c|c|c|c|c|c|c|}
\hline \multirow[t]{2}{*}{ Country } & \multirow{2}{*}{$\begin{array}{l}\text { Total fiscal } \\
\text { stimulus } \\
\text { (USD } \\
\text { billion) }\end{array}$} & \multicolumn{3}{|c|}{ Green stimulus (USD billion) } & \multirow{2}{*}{$\begin{array}{l}\text { GDP, USD } \\
\text { billion, 2007 } \\
\text { (purchasing } \\
\text { power parity) }\end{array}$} & \multirow{2}{*}{$\begin{array}{l}\text { Green } \\
\text { stimulus as } \\
\text { percentage of } \\
\text { total stimulus }\end{array}$} & \multirow{2}{*}{$\begin{array}{l}\text { Green } \\
\text { stimulus as } \\
\text { percentage } \\
\text { of GDP }\end{array}$} \\
\hline & & $\begin{array}{l}\text { Low } \\
\text { carbon* }\end{array}$ & Other & Total & & & \\
\hline Argentina & 13,2 & 0.0 & 0.0 & 0.0 & 526.4 & $0.0 \%$ & $0.0 \%$ \\
\hline Australia & 43,8 & 9.3 & 0.0 & 9.3 & 773.0 & $21.2 \%$ & $1.2 \%$ \\
\hline Brazil & 3.6 & 0.0 & 0.0 & 0.0 & $1,849.0$ & $0.0 \%$ & $0.0 \%$ \\
\hline Canada & 31.8 & 2.5 & 0.3 & 2.8 & $1,271.0$ & $8.3 \%$ & $0.2 \%$ \\
\hline China & 647.5 & 175.1 & 41.3 & 216.4 & $7,099.0$ & $33.4 \%$ & $3.0 \%$ \\
\hline France & 33.7 & 7.1 & 0.0 & 7.1 & $2,075.0$ & $21.2 \%$ & $0.3 \%$ \\
\hline Germany & 104.8 & 13.8 & 0.0 & 13.8 & $2,807.0$ & $13.2 \%$ & $0.5 \%$ \\
\hline India & 13.7 & 0.0 & 0.0 & 0.0 & $2,966.0$ & $0.0 \%$ & $0.0 \%$ \\
\hline Indonesia & 5.9 & 0.0 & 0.0 & 0.0 & 843.7 & $1.7 \%$ & $0.0 \%$ \\
\hline Italy & 103.5 & 1.3 & 0.0 & 1.3 & $1,800.0$ & $1.3 \%$ & $0.1 \%$ \\
\hline Japan & 639.9 & 36.0 & 0,0 & 36.0 & $4,272.0$ & $5.6 \%$ & $0.8 \%$ \\
\hline Mexico & 7.7 & 0.8 & 0.0 & 0.8 & $1,353.0$ & $9.7 \%$ & $0.1 \%$ \\
\hline Russia & 20.0 & 0.0 & 0.0 & 0.0 & $2,097.0$ & $0.0 \%$ & $0.0 \%$ \\
\hline Saudi Arabia & 126.8 & 0.0 & 9.5 & 9,5 & 546.0 & $7.5 \%$ & $1.7 \%$ \\
\hline South Africa & 7.5 & 0.7 & 0.1 & 0.8 & 467.8 & $10.7 \%$ & $0.2 \%$ \\
\hline South Korea & 38.1 & 14.7 & 21.6 & 36.3 & $1,206.0$ & $95.2 \%$ & $3.0 \%$ \\
\hline Turkey & 0.0 & 0.0 & 0.0 & 0.0 & 853.9 & - & $0.0 \%$ \\
\hline United Kingdom & 34.9 & 3.7 & 0.1 & 3.7 & $2,130.0$ & $10.6 \%$ & $0.2 \%$ \\
\hline United States $* *$ & 787.0 & 78.5 & 15.6 & 94.1 & $13,780.0$ & $12.0 \%$ & $0.7 \%$ \\
\hline European Union*** & 38.8 & 22.8 & 0.0 & 22.8 & $14,430.0$ & $58.7 \%$ & $0.2 \%$ \\
\hline Total G20 & $2,702.2$ & 366.3 & 88.4 & 454.7 & 63.145 .8 & $16.8 \%$ & $0.7 \%$ \\
\hline Total Other $* * * *$ & 314.1 & 7.6 & 1.0 & 8.6 & $6,902.9$ & $2.7 \%$ & $0.1 \%$ \\
\hline Global Total & $3,016.3$ & 373.9 & 89.4 & 463.3 & $65,610.0$ & $15.4 \%$ & $0.7 \%$ \\
\hline
\end{tabular}

Source: Barbier, E. (2009). 'Rethinking the Economic Recovery: A Global Green New Deal.' Report prepared for the

Economics and Trade Branch, Division of Technology, Industry and Economics, UNEP. Geneva.

http://www.unep.org/greeneconomy/docs/GGND-Report-April2009.pdf (accessed on 30 Oct. 2009)

* Includes support for renewable energy, carbon capture and sequestration, energy efficiency, public transport and rail, and improving electrical grid transmission.

** From the February 2009 American Recovery and Reinvestment Act) only. The October 2008 Emergency Economic Stabilization also included USD 185 billion in tax cuts and credits, including USD 18.2 billion for investments in wind, solar and carbon capture and storage.

*** Only the direct contribution by the EU is included (exclusive of the individual members' contributions).

**** Includes the national stimulus packages of non-G20 countries: Austria, Belgium, Chile, Greece, Hungary, Israel, Malaysia, the Netherlands, are New Zealand, Norway, Philippines, Poland, Portugal, Spain, Sweden Switzerland, Thailand and Vietnam. 


\subsection{Recommendations to Russian Financial Institutions}

\section{Evgeny Shvarts, Kamila Ilyumzhinova, Ivetta Gerasimchuk, Kevin Smith and Georg Kraft}

Background. The 2008/9 financial crisis has provided a number of valuable lessons to both the international and Russian financial sectors, amongst others:

- the importance of having prudent and comprehensive risk management practices in place particularly in light of the fact that the crisis has to a significant degree resulted from a lack of understanding on the part of FIs of how to accurately consider, price and manage the risks to which they are subjected; this is especially true in the case of complex financial instruments;

- the importance of solid asset and liability management. In certain instances, there existed a mismatch between the maturity periods of assets and liabilities, with many banks having raised a significant amounts of short-term debt in foreign capital markets, with these debts secured primarily against long-term assets;

- the need for a substantial rebalancing of the debt profile of Russian banks and corporations, with a greater proportion of funding being raised within the country (or in other word, a requirement to significantly increase the domestic deposits base).

Although the correlation between environmental factors and the financial performance of both lenders and investors is complex, it is clear that Russia's FIs should strongly consider environmental factors for the following reasons:

- Environmental issues can damage a financial institution's reputation, brand and image;

- There exists a direct cause-effect relationship between environmental damage or contamination, and the default probability of a borrower responsible for such damage;

- Land contamination has traditionally led to the reduction in the collateral value of property;

- Climate change regulation may create significant new liabilities for FIs, as well as for the clients of these institutions that hold significant carbon exposure;

- Environmental damage can degrade the general quality of assets in the Russian economy.

The majority of lending institutions have recognised that sound environmental due diligence and impact assessment procedures provide an effective means to both evaluate and mitigate these types of risks, and many of these FIs rigorously apply these procedures at a company, project and investment target levels.

Leading FIs hold significant potential to assume a more proactive role than merely applying sound environmental impact assessment (EIA) procedures, and could in fact find themselves at the forefront of the required global transition to a low carbon economy. Increasingly, Russian banks are beginning to realise their indirect role in promoting the degradation of Russia's environment, through their activities in providing financing for large-scale environmentally unsustainable projects. Moreover, this indirect environmental impact is likely to increase significantly as a result of the current liquidity crisis, as Russian banks are directed to play a more active role in supporting real economy sectors.

This applies in particular to those banks that receive state aid. On 22 April 2009, at a meeting with representatives of the financial sector, Russia's Prime Minister, Vladimir Putin, made a clear statement regarding the importance of greater accountability of banks that receive state aid, in their lending activities in the real sectors of the economy.

Proposed measures. In terms of increased environmental responsibility and accountability on the part of Russian FIs, WWF would propose the following measures: 
- Harmonisation of internal guidelines and policies of Russian FIs with existing best practice, particularly as represented by various internationally recognised sustainability guidelines, such as the IFC Performance Standards, the social and environmental standards of the EBRD and Asian Development Bank, the OECD 'Common Approaches on Environment and Officially Supported Export Credits', Equator Principles, UN Principles for Responsible Investment and various others (see Section 1.3. of the report). These mechanisms could serve as banking industry benchmarks for lending and portfolio investment activities, and Russian banks could make use of these international sustainability practices in the development of their own policies;

- Disclosure of non-financial information to all stakeholders, for example, in the form of corporate social responsibility reporting in line with international standards;

- Establishment of transparent compliance and grievance mechanisms and platforms for an open dialogue with civil society and local communities, particularly in instances where these parties are identified as affected stakeholders in project financing transactions. Russia holds an extensive record of large-scale projects that are clearly identified by the local NGO community as environmentally destructive. Russian FIs are therefore urged to demonstrate an understanding of the issues related to the destruction of natural resources, ecosystems and habitats, that are often associated with corporate and project financing transactions;

- The introduction of differential lending regimes, in terms of interest rates and loan conditions applicable to various transactions, according to the environmental and social profiles of borrowers and projects; for example, preferential loan conditions (in terms of longer loan terms and/or lower financing charges) for energy- and resource-efficient projects, and higher rates for polluting and/or energy-intensive clients;

- The promotion of various 'green office' initiatives in the internal operations of Russian FIs, for example, the use of Forest Stewardship Council (FSC) certified and recycled paper, the implementation of energy (and cost) saving schemes such as teleconferencing instead of business travel, establishment of an internal environmental management system and its certification under ISO 14000, and the offsetting of carbon footprint from office activities and employees travel through the purchase of tradable renewable energy certificates or support for sustainable afforestation projects;

- The development of innovative 'green' financial products such as 'low-carbon' mutual funds, through which Russian FIs might become market leaders in the global transition to an energy-efficient economy;

- The pricing of carbon into proposed financing transactions, even as a scenario-planning exercise, possibly at an illustrative cost equivalent to the current market price of carbon credits in the EU, or some similar measure. ${ }^{50}$ This is particularly relevant for FIs involved in export credit financing, in terms of retaining the competitiveness of Russia's exports to the EU, especially in light of the high concentration of embedded GHG in Russian exports (over 21 percent of total export value), ${ }^{51}$ and the possibility of border tax adjustments for embedded carbon, as recently proposed by various EU members states.

\footnotetext{
50 The price of carbon credits on the European Union Emissions Trading System, during September 2009, was approximately EUR 13-15 / ton CO2 equivalent.

${ }_{51}$ Jiang K., A. Cosbey, and D. Murphy. 'Embedded Carbon in Traded Goods.' Paper presented at the Trade and Climate Change Seminar Copenhagen, Denmark, 18-20 Jun. 2008.
} 
[Pure Profit for Russia: Benefits of Responsible Finance]

\title{
3.4. What Does it Take for a Financial Institution to Become 'Green'?
}

\author{
Mark Eckstein and Ivetta Gerasimchuk
}

The question posed as a title of this section is a complex one, and the answer is multifaceted in nature. There is little doubt, however, that the first and possibly most important element that is required for a substantial shift towards environmental responsibility on the part of a FI is a commitment by its senior management to undertake such as shift, assisted by proactive roles of risk managers, corporate social responsibility teams and other staff. At the same time, however, the development of a sustainability framework and action plan cannot take place in a corporate 'ivory tower'. On the contrary, it requires participation and incorporation of internal stakeholders (e.g. risk and credit staff, deal/ transaction and relationship managers, legal staff), consultations with key clients and other affected external stakeholders (regulators, NGOs, industry associations, etc).

As evidenced by the experiences of various international FIs described in Chapter One, different FIs can take varying approaches to the integration of social and environmental responsibility mechanisms into their business practices. Some institutions will seek to design and implement internal responsibility structures and operate in relative isolation, while others might undertake ESG activities primarily through membership of internationally recognised peer networks such as the Equator Principles and UN PRI. While such policy choices have always to be flexible to reflect the differences in sizes, structures, ownerships and ambitions of FIs, the key factors for a successful responsibility performance remain consistent. These include a clear policy vision and an uncomplicated, but targeted responsibility action plan with measurable indicators, the availability of effective channels for internal and external communication regarding ESG issues, the existence of compliance and grievance mechanisms, and the integration of ESG issues unto all activities and components of the organisation rather than a situation in which these issues are confined to a particular business unit.

It would appear that a well-proven strategy for the adoption of environmental and social responsibility mechanisms on the part of FIs is through the application of these mechanisms in one particular industry sector, for example forestry or fisheries, and the subsequent expansion into somewhat more "risky" sectors. In a similar fashion, the initial focus would appear to favour "high risk" financial products such as project and export credit finance, with expansion to a broader range of financial products (initial public offerings, corporate loans, etc) at a later stage.

Some important considerations for FIs in the development of sustainability procedures include the following:

- The identification of particular sustainability "fields" (for example, mitigation of risks associated with clients concentrated in one environmentally-intensive industry, advisory services on emissions trading and energy-efficiency) that can contribute to the financial and other targets of the institution in terms of income generation or cost / risk reduction;

- Agreement on what sustainability standards will apply to which financial products;

- The development of policies and procedures to clarify and describe the sustainability approach chosen by the FI to its staff and other stakeholders, including owners, regulators, etc; and

- An assessment of resource, training and communication implications inherent to the adaptation of the chosen approach. 


\section{Figure 13. Integrating 'Green' Responsibility Standards from Scratch: a Generic Roadmap for Russian FIs}

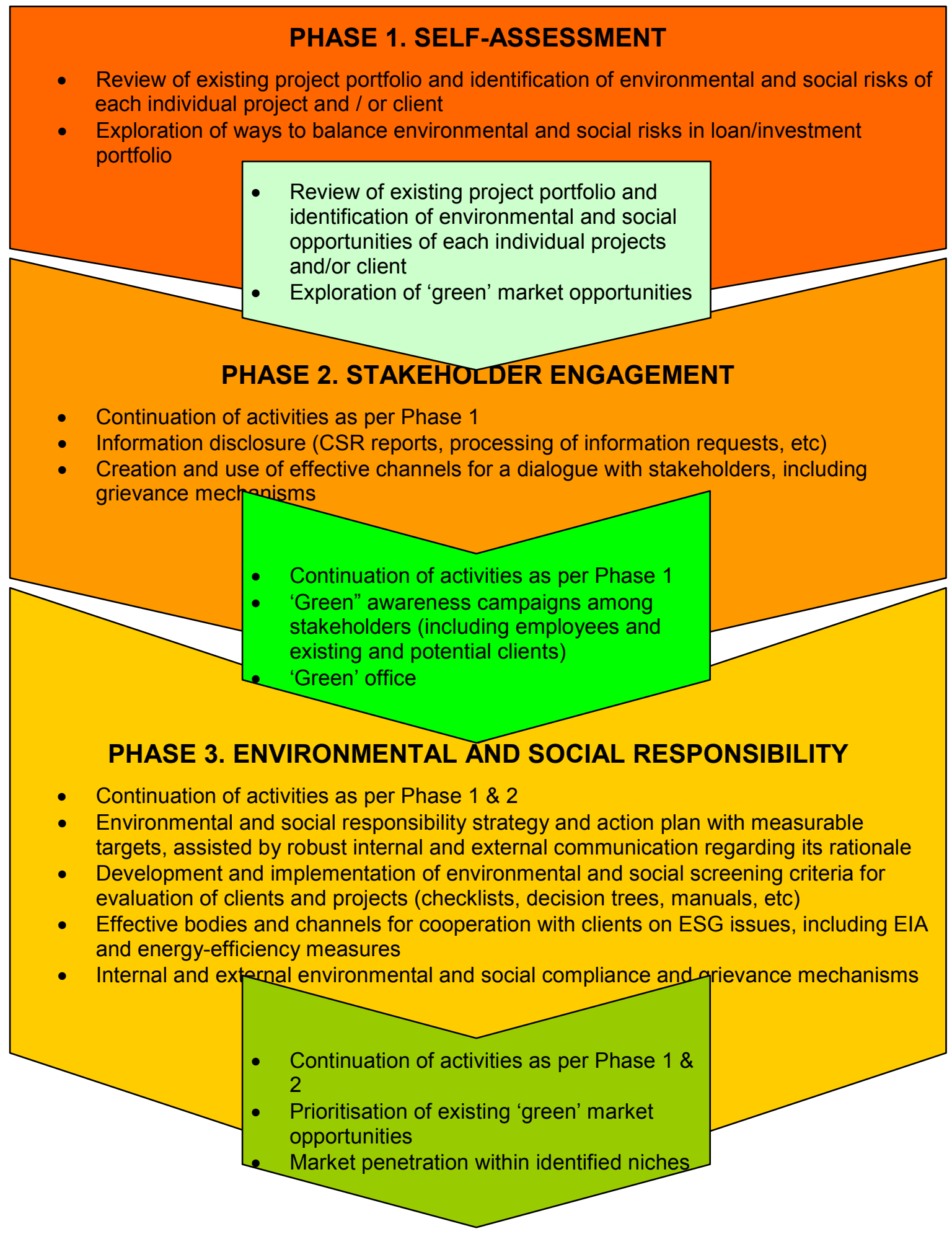

Source: WWF-Russia.

Note: Larger arrows stand for the social and environmental responsibility of FIs in a broad sense (recognition and management of the environmental and social risks inherent in projects to which finance is provided), while smaller arrows refer to the narrow definition of responsible finance (financing of specifically targeted socially and environmentally beneficial projects). 
As an example, HypoVereinsbank has analysed the additional time and costs implications related to the application of the Equator Principles in its loans categorised as Category A projects (projects with high extra-financial risk). According to the Bank's estimates, the additional time taken by a project officer to screen and structure these extra-financial risks made up four percent of the overall time dedicated to the deal. Furthermore, in Category A deals, the additional independent external advisory costs incurred (covering environmental, social and legal aspects), equated to less than 0.01 percent of the total project costs, which corresponds to an increase in technical due diligence costs of between 15 and 20 percent per a Category A deal. ${ }^{52}$ As discussed in Section 3.1 above, the cost of implementing environmental assessment procedures according to the FI standards is as a rule passed on borrowers.

In keeping with the distinction between broad and narrow scopes of social and environmental responsibility on the part of FIs, as described in Section 1.2 of the report, Figure 13 maps a logical framework for Russian FIs' integration of 'green' responsibility standards from scratch.

As a further illustration, the Addenda section of this report provides a first-hand description of the experience of adopting and implementing the EPs, written by Mr. Osamu Odawara, Senior Vice President and Head of the Sustainable Development Department at Mizuho Corporate Bank.

\section{Environmental and Social Risk Managers:}

\section{SHypoVereinsbank \\ Unicredit Group}

- Develop and maintain Bank Policies and Procedures - such as the Equator Principles Manual.

- Provide oversight of new business and portfolio risks and provide sustainability input into key decisions that are based on sustainability risks and opportunities.

- Develop and maintain files and document rationale for each transaction.

- Train staff, and develop sustainability materials for new staff, updates for existing staff on new rules, policies and trends such as carbon finance, etc.

- Develop a Sustainability Training Toolkit both for Business Origination and for Credit Risk Functions.

- Keep management updated on critical, high risk projects which may create reputational or investment risks.

- Undertake transparent environmental review and disclose findings to deal teams.

- Involvement in, and structuring of Action Plans and covenants in Loan Documentation.

- Liaison with clients, peers, NGO's and others.

- Provide input to Bank's Sustainability Report.

Source: WWF and China Outreach Partners (2009). 'Capacity Building and Best Practice Materials Developed for the Chinese Financial Sector by a Consortium of Financial Institutions and WWF.' ANZ, DEG, Euler Hermes, FMO, Standard Chartered, Unicredit/HCB, West LB and WWF.

\footnotetext{
${ }^{52}$ WWF and China Outreach Partners (2009). 'Capacity Building and Best Practice Materials Developed for the Chinese Financial Sector by a Consortia of Financial Institutions and WWF.' ANZ, DEG, Euler Hermes, FMO, Standard Chartered, Unicredit/HCB, West LB and WWF.
} 
Good practice suggests that designated sustainability teams play a crucial role in implementing sustainability policies in a FI. Such teams are usually staffed with between one and five employees and are often linked with the credit risk or legal departments. The skills represented in a sustainability team of a FI should include financial, environmental, social and legal capacities.

In general, sustainability teams take the lead on the development of environmental and social responsibility policies and procedures at a FI, but they are of course required to collaborate with other divisions in the implementation of these policies and procedures. These teams therefore need to be proactive in recognising the particular challenges that are being created for relationship managers and deal-makers, and actively assist in developing solutions to address those challenges. Sustainability staff should be available to provide relevant guidance and recommendations to relationship managers and credit risk teams but need not necessarily be involved in every deal signed by the FI. Depending on the scope and scale of environmental and social risks attached to a particular deal, sustainability teams might take a proportionally active role in client assessment, preparatory work and further through out the investment lifecycle. This role may vary from no involvement in cases of zero or insignificant environmental and social impact of the transaction, to ongoing consultation and involvement in the case of high-risk investments.

\section{EHI EULER HERMES}

Almost all client applications for Euler Hermes services are screened and reviewed by the Sustainability Team (DST). Only 'standard' applications where the underwriter knows that the application does not fall under the scope of the 'Common Approaches' or that the project type is environmentally not sensitive, are not screened by the DST.

The DST includes six full time staff members comprised of a head, an engineer, two environmental scientists, a lawyer and an economic expert. This organisational solution has proven to be effective and timely in terms of project support and as a result there have been positive outcomes such as:

- Increased environmental know-how despite increased work load, less delays in review process (as opposed to delays due to coordination between two units under an alternative organisational structure), more efficient review process.

- Direct contact person for environmental issues for exporters (before and during application), enabling clarification of questions on the technical level.

- Workshops organised by the DST with exporters in which requirements (scope of review, information requirements, applicable standards etc) were explained. This leads to a better understanding by clients (exporters) of what is required under the OECD 'Common Approaches' and to more engagement of exporters. Quality of information provided by clients has improved, resulting in a more efficient review process.

- More structured and clearer information on environmental aspects in reports to the Guardian Authorities (technical/environmental experts 'filtering' relevant information).

- Less criticism from NGOs on specific projects.

Source: WWF and China Outreach Partners (2009). 'Capacity Building and Best Practice Materials Developed for the Chinese Financial Sector by a Consortium of Financial Institutions and WWF.' ANZ, DEG, Euler Hermes, FMO, Standard Chartered, Unicredit/HCB, West LB and WWF. 
The text boxes contain firstly a job description for Environmental and Social Risk Managers at HypoVereinsbank, the second largest FI in Germany and a signatory of the Equator Principles, and secondly the organisational experience of Euler Hermes, a French credit insurance company applying the OECD 'Common Approaches'.

As mentioned above, the sustainability team of a FI might play a role over the entire life time of an investment, involving four stages, as follows:

1. Preliminary Screening. As soon as a potential client approaches a FI for funding, prospective transactions are screened by relationship managers and the sustainability team in order to identify risks and opportunities. In case where the risks attached to the transaction might be high, relevant consultations should be held not only between relationship and sustainability teams, but also with the credit risk teams and senior management (Figure 14). Categorisation of projects as having high, medium, or low environmental and social risks (A, B or $\mathrm{C}$ respectively according to the IFC/EBRD/Equator Principles classification) is a sensitive issue and might be a point of disagreement with stakeholders.

At this stage, FIs usually apply specially designed tools that assist them to make categorisation and other decisions, and assess compliance risk. These tools need not be complicated, and usually amount to sector checklists and decision trees. Industry sector checklists often include 10-15 questions regarding the key risks and issues: (a) sector risks and performance norms; (b) industry trends and drivers; (c) client capacity, commitment and track record; and (d) sector-specific guidance for investment teams. Examples of such industry sector checklists can, as a rule, be obtained from the websites of individual banks, where they are made available for the convenience of clients.

Figure 14. Internal Consultations among FI's Teams for Making Responsible Decisions

\begin{tabular}{|c|c|c|c|}
\hline & High & Medium & Low \\
\hline$\frac{\sqrt{0.00}}{\underline{.00}}$ & $\begin{array}{l}\text { Consult credit risk and } \\
\text { sustainability teams and senior } \\
\text { management }\end{array}$ & $\begin{array}{l}\text { Consult credit risk and } \\
\text { sustainability teams }\end{array}$ & $\begin{array}{l}\text { Delegate decision to } \\
\text { deal/investment team }\end{array}$ \\
\hline 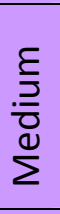 & $\begin{array}{l}\text { Consult credit risk and } \\
\text { sustainability teams }\end{array}$ & $\begin{array}{l}\text { Consult sustainability team } \\
\text { and seek advice on issues } \\
\text { before undertaking due } \\
\text { diligence }\end{array}$ & $\begin{array}{l}\text { Delegate decision to } \\
\text { deal/investment team }\end{array}$ \\
\hline 3. & Consult sustainability team & $\begin{array}{l}\text { Delegate decision to } \\
\text { deal/investment team }\end{array}$ & $\begin{array}{l}\text { Delegate decision to } \\
\text { deal/investment team }\end{array}$ \\
\hline
\end{tabular}

Source: WWF and China Outreach Partners (2009). 'Capacity Building and Best Practice Materials Developed for the Chinese Financial Sector by a Consortium of Financial Institutions and WWF.' ANZ, DEG, Euler Hermes, FMO, Standard Chartered, Unicredit/HCB, West LB and WWF.

Based on the outcomes of the preliminary screening, all the internal teams of the FI should agree on the approach to a particular client in terms of applicable standards and the case for requiring these as part of the transaction. The FI will then prepare a business offer for the client in order to help address the identified sustainability risks and opportunities according to the logic outlined in Figure 15. 
Figure 15. The Hierarchy of Options to Address Environmental and Social Risks.

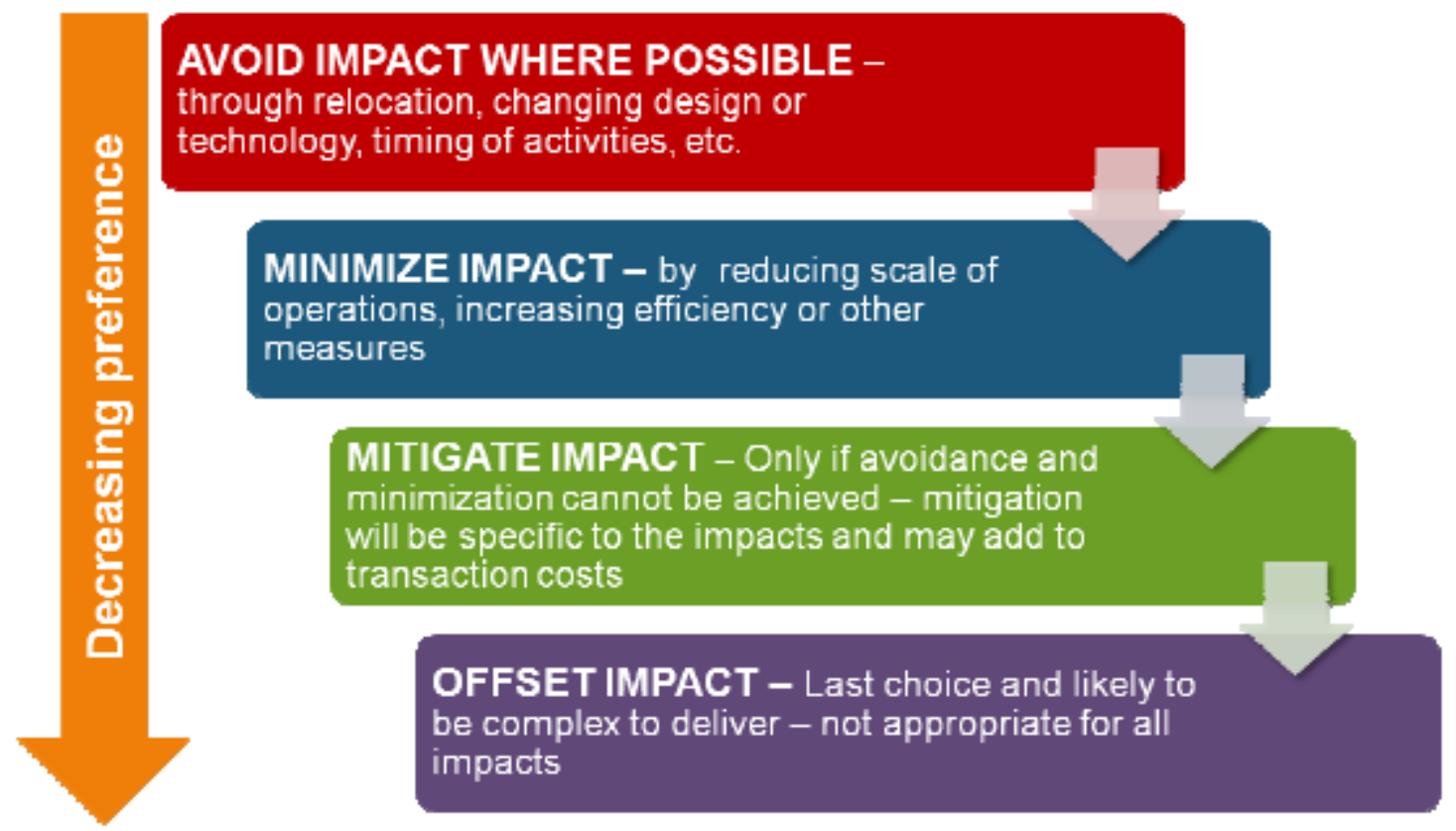

Source: WWF and China Outreach Partners (2009). 'Capacity Building and Best Practice Materials Developed for the Chinese Financial Sector by a Consortium of Financial Institutions and WWF.' ANZ, DEG, Euler Hermes, FMO, Standard Chartered, Unicredit/HCB, West LB and WWF.

\section{Figure 16. Four Criteria for an Efficient Public Consultation under a FI's Responsibility Framework}

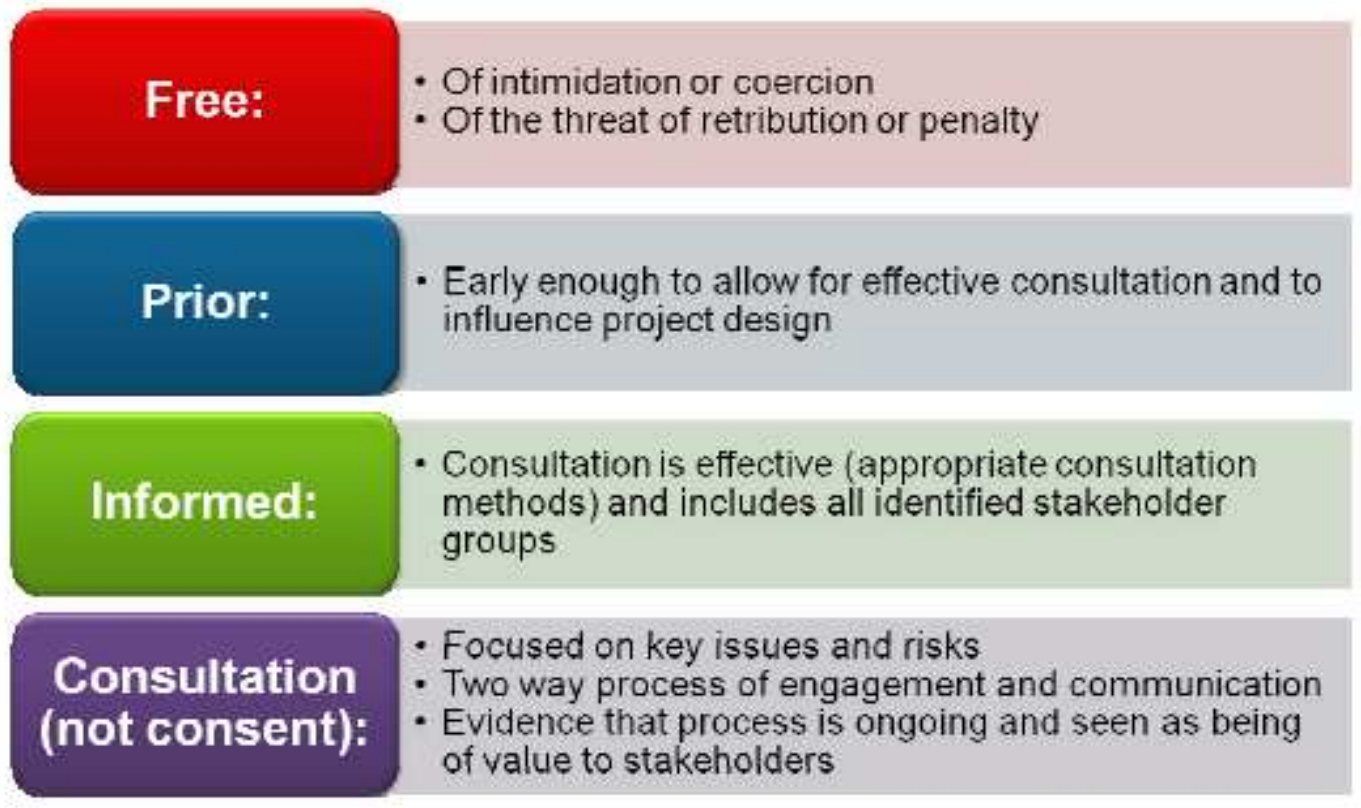

Source: WWF and China Outreach Partners (2009). 'Capacity Building and Best Practice Materials Developed for the Chinese Financial Sector by a Consortium of Financial Institutions and WWF.' ANZ, DEG, Euler Hermes, FMO, Standard Chartered, Unicredit/HCB, West LB and WWF. 
2. Due Diligence. The sustainability team will review the transaction according to the FI's environmental and social screening manual or a similar guideline and complete the necessary internal paperwork. The sustainability group will also evaluate the completeness of the client's environmental assessment / audit and determine the need, or lack thereof, for involving external consultants. At this stage, for projects with significant environmental and social risks and impacts, particular attention should also be paid to an assessment of the public consultation processes undertaken by the client, in line with the criteria described in Figure 16. In some cases additional public consultations may be required, with corresponding implications for flow and timeline of the deal. The sustainability team will also assess the client's capacity and commitment to achieve compliance, as well as discuss and agree with the client the manner in which any compliance deficiencies will be addressed. It is essential to ensure that these agreements are incorporated in the action plans developed for the deal, and also that the necessary leverage mechanisms to ensure compliance are built into the deal.

3. Structuring and Approval. The sustainability team will provide concise summary of the principal risks and requirements of the FI (in the form of environmental and social management systems, action plans, etc). Specific requirements in this regard must be incorporated into the deal contracts and leverage to ensure compliance must be maintained following the disbursement of funds.

4. Monitoring. Monitoring of existing projects is an equally important task for the sustainability team in spite of the persistent (and somewhat natural) tendency to focus on new business. It is important to ensure that clients are managing the sustainability risks associated with the financed projects, and are complying with the bank's requirements in terms of the agreed action plans and other measures. On an annual basis, the sustainability team reviews the environmental and social performance of the clients, who are obliged to relevant reporting and public information disclosure. The level and intensity of these follow-up and monitoring activities should be in direct proportion to the sustainability risks associated with a particular project.

Increasingly, sustainability teams are also required to service the "opportunities" aspect of a FI's business, such as investigating the potential of investment in carbon markets, or providing advice regarding the environmental soundness of foreign trade, improvement of energy-efficiency, etc. As a result, these teams need to possess a broad range of skills, in terms of both understanding risks and identifying new opportunities. 


\section{CONCLUSION}

\section{Ivetta Gerasimchuk and Kamila Ilyumzhinova}

This report attempts to quantify the scale of exposure on the part of both foreign and Russian FIs to environment-intensive sectors of the Russian economy and to explore the prospects for positioning finance as a driver of sustainable development in Russia, similar to the manner in which this process is underway in other emerging markets such as China, Brazil and South Africa.

While the analysis has succeeded in identifying a range of international and domestic FIs which lend into environment-intensive sectors in Russia, the task of finding effective ways to "green" the financial resources of the Russian economy has proven more difficult. The structure of the Russian financial sector and the resultant prerequisites for its environmental awareness have little in common with the situations in China, Brazil or South Africa.

In contrast to China, Russia lacks financial self-sufficiency and is as a result highly reliant on foreign capital markets - those in Europe, North America, Japan and, increasingly, China. Furthermore, unlike in China and South Africa, the Russian government has instituted relatively limited measures in terms of policy, legislation and enforcement capacity to ensure improvements in energy- and resource-efficiency of the national economy and the "greening" of the financial and corporate sectors. As discussed in Section 3.2, China is the world leader in terms of absolute levels of "green" investments (USD 216.4 billion) to be injected by the government into the national economy as part of a stimulus package to overcome the financial crisis. It addition to its primary functions, the People's Bank of China has taken up responsibility for improving the risk management practices by the country's FIs, including the management of environmental and social risks in their loans portfolios. By contrast, the Russian Central Bank is preoccupied with consolidating the Russian banking sector and maintaining the stability of the national currency, a particularly challenging task, given the externally driven fluctuations in the balance of payments. Finally, Russian FIs are far less active abroad than their Chinese counterparts, and are therefore far less exposed to international competitiveness pressures, which include the environmental and social profile of funded projects.

Unlike in Brazil and South Africa, Russian FIs are subject to a very low level of environmental requirements and demands from the country's citizens and foreign direct investors. As a result, the performance of FIs and their clients is generally less closely linked with their environmental and social practices than is the case in other countries. Whereas the Brazilian Stock Exchange, for example, plays a proactive role in promoting responsible investment, Russian stock exchanges and financial industry associations, by contrast, are for the most part ignorant of the potential for environmental and social considerations to improve the sector's competitiveness.

With regard to the environmental and social profile of the financial sector, the situation in Russia is somewhat similar to that in India, which also lags behind other emerging markets in the adoption of internationally recognised responsibility mechanisms. This parallel is even more obvious when considering the massive environmental challenges that remain to be addressed in both Russia and India by all actors in the economies of those countries, including the financial sector.

It would appear that in terms of the integration of environmental sustainability considerations into economic development policies in general, and into financial sector decision-making processes in particular, Russia can follow either the Chinese or Brazilian model. Adoption of the Chinese model will require a significant increase in the level of attention to environmental issues on the part of the Russian government, state-owned corporations and state-owned banks. It is however important that such attention is directed not only towards the nature protection function of the government per se, which is performed by one ministry, but rather towards the integration of sustainability drivers into the entire 
spectrum of economic policies, with the aim of promoting "green" development as a means to improve the country's international competitiveness. Such process implies a complete departure from the commonly held perceptions on the part of many Russian officials and businessmen that environmental requirements and responsibility hold only costs, trade-offs and no real synergies with economic advancements.

At the same time, in light of the increasing role of the state in the Russian economy, including by means of stimulus measures to counter the 2008/9 financial crisis, there exist a number of prerequisites for the implementation of this scenario. In particular, given the ambitions of some state-owned banks such as Sberbank, VEB and VTB to play a more significant role in the global arena, it seems likely that the adoption of international sustainability mechanisms will become increasingly important and appropriate for these institutions.

Implementation of the Brazilian scenario in Russia will require a higher level of integration of the country into the global economy and an increasing role for both national and international civil society institutions in decision-making processes. In this regard, the fact that Russia is already so much dependent on external capital markets, can provide positive impacts for integration of the environmental and social considerations in the country's business practices. Many Western and Japanese banks that provide loans to the Russian corporate sector are signatories of the Equator Principles and other responsibility benchmarks, and as these mechanisms evolve, their application in Russia will also become more stringent. The most lucrative clients in Russia, including oil and gas companies, tap into international financial markets and are therefore accustomed to applying the international responsibility mechanisms required by these investors. There is therefore no evidence to suggest that avoidance of international responsibility frameworks will make Russian FIs somehow more attractive to potential clients than their foreign competitors.

In line with international trends, it would appear that the first moves to adopt internationally recognised mechanisms of social and environmental responsibility in Russia are likely to come from Russian subsidiaries of foreign FIs and financial intermediaries of multilateral institutions such as EBRD and IFC. It would also appear likely that some regional and medium-sized Russian banks might be motivated to utilise the aspect of environmental and social responsibility as a distinguishing feature and thereby improve their access to international capital markets. This is particularly the case in the highly competitive "differentiate or die" post-crisis scenario, in which issuers with no sovereign support are competing with other private banking institutions from all over the world, and especially from other BRICS.

As discussed in Sections 1.6 and 3.2, however, the area of project finance, which is covered by the Equator Principles, accounts only for a small fraction of the capital raised by Russian companies that are active in environment-intensive sectors. Although there exists, as mentioned above, a trend towards harmonisation of existing international responsibility benchmarks for the financial sector, this process will require significant progress before these mechanisms can be applied in areas such as corporate finance, which is the principal source of capital in Russia. Furthermore, lending institutions providing project and corporate loans are not the sole providers of external financing in Russia. In fact, the Eurobonds' market in the country is comparable in size to that of the syndicated loans market. It would therefore be inappropriate to insist that only the foreign and domestic banking sectors should be accountable for the potential environmental damage resulting from the projects that they finance. Institutional investors, the majority of whom are loath to disclose information regarding their portfolios, have traditionally injected significant funding into emerging market economies. Due to the far more "intangible" nature of the asset management and portfolio investment sectors, existing socioenvironmental guidelines such as the UN PRI do not include any relatively straightforward measures of environmental and social responsibility such as Environmental Impact Assessment, in the manner that the Equator Principles do. 
Finally, the growing reliance within Russia on Chinese finance is sure to become an increasingly controversial issue. Although the Chinese financial sector is embracing responsibility standards under the guidance of the People's Bank of China, this process has to date primarily focused on loans provided by Chinese banks in the domestic market rather than abroad where Chinese institutions finance environment-intensive projects. In 2006 - 2009, China Development Bank provided financing of at least USD 25 billions to Russian oil companies in the form of corporate loans, which under current conditions are not subject to the Equator Principles even if this bank was a signatory of the Equator Principles, which it is not. Russian civil society institutions have yet to learn how to work with the increasingly more active Chinese players in the Russian economy.

A third possible scenario for Russia may be to avoid following either the Chinese or Brazilian models of ESG responsibility, and rather remain in its current environmental policy vacuum for a number of years. This might imply a prolonged delay of important decisions, as was the case for Russia's ratification of the Kyoto Protocol and subsequent development of the internal legal framework for participation in international trade in emissions quotas. Nevertheless, the cost of such inaction is particularly high not only for the government, but also for domestic and international companies operating in Russia without clear policy signals that would allow them to start plan strategically instead of their current myopic approach to business, the society and the environment. Such a policy vacuum might also imply significant reputational risk for Russia in the international arena, as it would signal a lack of willingness on the part of the government to engage in environmental and social issues.

However, sound environmental policies and application of FIs' responsibility benchmarks such as the OECD "Common Approaches" are adherent to membership in the Organisation for Economic Cooperation and Development currently sought by Russia. Therefore the integration of environmental and social responsibility standards into the Russian financial sector appears to be a question of "when" rather than "if".

At the same time, global experience would suggest that market leaders are never those who wait for guidance from authorities, but rather those who foresee emerging market opportunities and explore uncharted territories. In this context, the area of sustainable finance in Russia offers major opportunities. The experiences of IFC and EBRD are testament to the fact that environmentally responsible and progressive investments are possible in Russia, and that energy efficiency measures in particular can prove extremely attractive for FIs from a commercial point of view. One issue that reoccurs on an ongoing basis in the Russian context concerns a lack of awareness regarding the benefits of energy efficiency to the economy in general and to heavy industry in particular. It may therefore be assumed that if Russian banks begin incorporating the issue into their investment decisions and activities, awareness on the part of their clients in this regard is certain to increase in a corresponding fashion. According to the IFC's annual client survey conducted in 2006, the third most important factor for clients in terms of entering into a partnership with IFC was the assistance that the organisation provides in managing environmental and social issues (see Section 2.3 of the report for further details). The potential market for energy efficiency solutions in Russia is a huge one, and the benefits to be gained, in terms of carbon emissions reductions and the resulting benefits for the climate change agenda, are equally significant. There also exists significant potential for investments in renewable energy in Russia, particularly in wind power. Similarly, waste treatment is another area which will need to be addressed by Russian companies if they are to increase their international competitiveness.

From the viewpoint of WWF, the most realistic scenario for the development of responsible finance in Russia is for a few proactive FIs in the country to take the lead in the area of environmental and social sustainability, and thereby "turn the tables", making other players follow in order to retain competitiveness and market share. This report is intended to assist these anticipated market leaders in gaining the maximum benefit from a collective of international experience in responsible finance. 


\section{REFERENCES}

\section{Responsibility Frameworks and Policy Statements}

1. Basel Committee on Banking Supervision/Bank for International Settlements (2005). 'International Convergence of Capital Measurement and Capital Standards: A Revised Framework'. Basel Committee on Banking Supervision/Bank for International Settlements, Basel. http://www.bis.org/publ/bcbs118.pdf. (accessed on 30 Oct. 2009)

2. The Collevecchio Declaration (2003).

http://www.banktrack.org/download/collevecchio_declaration_2/0_030401_collevecchio_declaration.pdf (accessed on 30 Oct. 2009)

3. Equator Principles (2006). "The "Equator Principles": A Financial Industry Benchmark for Determining, Assessing and Managing Social and Environmental Risk in Project Finance'. www.equator-principles.com

4. The Gleneagles Communiqué (2005).

http://www.unglobalcompact.org/docs/about_the_gc/government_support/PostG8_Gleneagles_Communique.pdf (accessed on 30 Oct. 2009)

5. IFC/IBRD (2008). 'Energy Efficiency in Russia: Untapped Reserves'. World Bank Group, Washington D.C. http://www.ifc.org/ifcext/rsefp.nsf/AttachmentsByTitle/FINAL_EE_report_Engl.pdf (accessed on 30 Oct. 2009)

6. IFC (2006). 'International Finance Corporation's Policy on Social \& Environmental Sustainability.' IFC, Washington $\quad$ D.C. http://www.ifc.org/ifcext/sustainability.nsf/AttachmentsByTitle/pol_SocEnvSustainability2006/\$FILE/Sustainabilit yPolicy.pdf (accessed on 30 Oct. 2009)

7. IFC EHS Guidelines. www.ifc.org/enviro

8. OECD (2007). 'Recommendation on Common Approaches on the Environment and Officially Supported Export Credits.' OECD, Paris. http://www.olis.oecd.org/olis/2007doc.nsf/linkto/tad-ecg(2007)9 (accessed on 30 Oct. 2009)

9. World Bank and IFC (1999). 'Pollution Prevention and Abatement Handbook: Toward Cleaner Production.' World Bank and IFC, Washington D.C. http://www.ifc.org/ifcext/sustainability.nsf/AttachmentsByTitle/p_ppah/\$FILE/PPAH.pdf (accessed on 30 Oct. 2009)

10. World Bank’s Operational Manual (constantly updated). http://www.worldbank.org/opmanual

\section{Journal Articles, Working Papers and Presentations}

11. Central Bank of http://www.cbr.ru/eng/analytics/bank_system/print.asp?file=bank_laws_e.htm (accessed on 30 Oct. 2009)

Note.

12. Jiang K., A. Cosbey, and D. Murphy. 'Embedded Carbon in Traded Goods.' Paper presented at the Trade and Climate Change Seminar Copenhagen, Denmark, 18-20 Jun. 2008.

13. Ling A. et al. (2007). 'Introducing GS SUSTAIN'. N.-Y.: Goldman Sachs Global Investment Research. Note 1. http://www.unglobalcompact.org/NewsandEvents/event_archives/2007_Leaders_Summit/S1_GOLDMAN_Ling.pdf (accessed on 30 Oct. 2009)

14. McCallion, T. (2009). 'EBRD: Mainstreaming Energy Efficiency across Banking Operations'. Presentation given at the 'Promotion of Sustainable Finance Mechanism in Russia' conference, Moscow, 29 Apr. 2009. http://wwf.ru/data/events/3/tmccallion ebrd.pdf (accessed on 30 Oct. 2009)

15. Odawara, O. The Equator Principles - a Framework for Managing Social and Environmental Risk in Project Finance / International Rivers Network (2008). 'New Financiers and the Environment: Ten Perspectives on How Financial Institutions Can Protect the Environment.' International Rivers Network, Berkeley. Pp. 26 - 27. http://www.esocialsciences.com/data/articles/Document11102009360.3584864.pdf (accessed on 30 Oct. 2009)

16. Polishchuk, L. (2009). 'Corporate Social Responsibility vs. Government Regulation: Institutional Analysis with an Application to Russia.' Higher School of Economics Working Paper. Moscow. http://www.hse.ru/data/393/364/1237/CSR_paper_revised.PDF (accessed on 30 Oct. 2009) 
17. Porter, M. and M. Kramer (2006). 'Strategy and Society: the Link between Competitive Advantage and Corporate Social Responsibility’. Harvard Business Review, Issue 84(12). Pp. 78 - 92.

18. Robinson, M. (2008). 'International Banking. A Unique Opportunity for Russia'. Presentation given to the Graduate School of Management, St. Petersburg, 10 Apr. 2008.

19. Standard Bank fact sheet: http://www.standardbank.co.za/SB FILES/Investor/SBfactsheet.pdf (accessed on 30 Oct. 2009)

20. Standard \& Poor's (2007). 'Bank Industry Risk Analysis: Russian Banks Continue To Improve, But Still Burdened By Structural Vulnerabilities'. Standard \& Poors, Moscow.

21. Uralsib / Уралсиб (2008). 'Capital Markets’ Prospects. Credit Crisis is Changing the Game Rules. Перспективы рынков капитала. Кредитный кризис меняет правила игры.' Uralsib, Debt Capital Market Research Department. Presentation at the $5^{\text {th }}$ Federal Investment Forum, Moscow, 18 Nov. 2008. http://www.fif.rcb.ru/2008/prezentation/ginsbyrg.ppt (accessed on 30 Oct. 2009)

22. WWF and China Outreach Partners (2009). 'Capacity Building and Best Practice Materials Developed for the Chinese Financial Sector by a Consortium of Financial Institutions and WWF.' ANZ, DEG, Euler Hermes, FMO, Standard Chartered, Unicredit/HCB, West LB and WWF.

\section{Monographs and Reports}

23. Barbier, E. (2009). 'Rethinking the Economic Recovery: A Global Green New Deal.' Report prepared for the Economics and Trade Branch, Division of Technology, Industry and Economics, UNEP. Geneva. http://www.unep.org/greeneconomy/docs/GGND-Report-April2009.pdf (accessed on 30 Oct. 2009)

24. Deutsche Bank (2008).'Economic Stimulus: The Case for 'Green' Infrastructure, Energy Security and 'Green' Jobs.' Deutsche Bank. http://www.dbadvisors.com/deam/stat/globalResearch/1113_GreenEconomicStimulus.pdf

25. EBRD (2009). 'Sustainable Energy Initiative: Action and Results 2006-2009'. EBRD, London. http://www.ebrd.com/pubs/cs/sei.pdf (accessed on 30 Oct. 2009)

26. Environmental Impact Assessment and Environmental Review. Russian-German Methodology Наndbook. / Оценка воздействия на окружающую среду и экологическая экспертиза. Российско-германское методологическое пособие. Irkutsk-Berlin-Bonn, 2008.

27. Gerasimchuk, I./ Герасимчук, И. (2007). 'Environmental Practice of Transnational Corporations / Экологическая практика транснациональных корпораций.' WWF Russia, Moscow. http:/wwf.ru/data/pub/gerasimchuk.pdf (accessed on 30 Oct. 2009)

28. IFC (2007). 'Banking on Sustainability. Financing Environmental and Social Opportunities in Emerging Markets. IFC, Washington.' http://www.ifc.org/ifcext/enviro.nsf/AttachmentsByTitle/p_BankingonSustainability/\$FILE/FINAL_IFC_BankingO nSustainability web.pdf (accessed on 30 Oct. 2009)

29. Independent Evaluation Group (2008). 'Environmental Sustainability: An Evaluation of World Bank Group Support'. World Bank Group Independent Evaluation Group, Washington D.C. http://web.worldbank.org/WBSITE/EXTERNAL/EXTOED/EXTENVIRONMENT/0, contentMDK:21826882 men uPK:4681948 pagePK:64829573 piPK:64829550 theSitePK:4681890 isCURL:Y,00.html (accessed on 30 Oct. 2009)

30. 'New Financiers and the Environment: Ten Perspectives on How Financial Institutions Can Protect the Environment.' International Rivers Network, Berkeley. http://www.esocialsciences.com/data/articles/Document11102009360.3584864.pdf (accessed on 30 Oct. 2009)

31. PBoC and WWF (2008). 'Towards Sustainable Development: Reform and Future of China's Banking Industry'. People's Bank of China (PBoC) and the WWF, Beijing. http://www.panda.org/index.cfm?uNewsID=146221 (accessed on 30 Oct. 2009)

32. World Bank (2009). State and Trends of the Carbon Market 2009. http://wbcarbonfinance.org/docs/State_Trends_of the_Carbon_Market_2009-FINAL_26_May09.pdf (accessed on 30 Oct. 2009)

\section{Press Articles and Media Releases}


33. BusinessNewEurope, 20 Dec. 2008. http://businessneweurope.eu/story1414/RUSSIA_2009_Paused_before_a_rally (accessed on 30 Oct. 2009)

34. Business Report. 24 Apr. 2007. http://www.busrep.co.za/index.php?fSectionId=553\&fArticleId=4370487

35. EBRD feature story. 7 Apr. 2008. http://www.ebrd.com/new/stories/2008/080407.htm (accessed on 30 Oct. 2009)

36. EBRD feature story. 21 May 2007. http://www.ebrd.com/new/pressrel/2007/070521b.htm (accessed on 30 Oct. 2009)

37. Handelsblatt, 16 July 2008. http://www.handelsblatt.com/technologie/nachhaltig_wirtschaften/oekologie-praegtprojektfinanzierung;2012267 (accessed on 30 Oct. 2009)

38. Estado de S. Paulo, 23 Jul. 2008. http://www.equator-principles.com/brasil vialli.shtml (accessed on 30 Oct. 2009)

39. Private Equity Council media release. 10 Feb. 2009. http://www.privateequitycouncil.org/pressreleases/2009/02/10/private-equity-council-members-adopt-guidelines-for-responsible-investment/ (accessed on 30 Oct. 2009)

40. Responsible Investor, 28 Jul. 2009. http://www.responsible-investor.com/home/article/pri_ejects/

41. Reuters, 8 May 2008. http://www.reuters.com/article/pressRelease/idUS142792+08-May-2008+BW20080508 (accessed on 30 Oct. 2009)

42. Smart Money. 9 Oct. 2006. http://www.smoney.ru/article.shtml?2006/10/09/1476

43. UN PRI media release, 20 Aug. 2009. http://www.unpri.org/files/delisting_final.pdf 


\section{ADDENDA}

\section{Glossary of Terms}

Biocapacity refers to the productivity of a certain area of land and water, in other words. the capacity to produce an ongoing supply of biological resources. WWF International publishes a biannual 'Living Planet Report' with updates on trends in changes of both biocapacity and ecological footprint. Internet: http://www.panda.org/livingplanet

BRICS is an acronym that refers to the fast-growing emerging market economies of Brazil, Russia, India, China and South Africa. The acronym was first coined and prominently used by Goldman Sachs in 2001 in its Global Economics Paper No. 99 titled "Dreaming with BRICs". This paper argued that, since they are developing so rapidly, by 2050 the combined economies of Brazil, Russia, India and China could eclipse the combined economies of the current richest countries of the world. Because of the popularity of the Goldman Sachs thesis "BRIC", this term has sometimes been extended to "BRICS+" (including Malaysia and Indonesia), "BRIMC" (including Mexico), "BRICA" (including Arab countries - Saudi Arabia, Qatar, Kuwait, Bahrain, Oman and the United Arab Emirates) and "BRICET" (including Eastern Europe and Turkey). These have all become more generic terms to refer to these emerging markets.

Carbon credit is a concept that came into place in conjunction with the Kyoto Protocol. This international agreement allows the recipient of such carbon credits, which are obtained through the implementation of carbon saving practices or projects (e.g. re-forestation or the implementation of renewable energy projects), to sell these carbon credits to companies or other entities that are unable to remain below their prescribed carbon emissions quota.

Carbon Disclosure Project (CDP) represents a group of close to 500 institutional investors (as of mid 2009) that includes some of the world's largest and best-known FIs such as HSBC, JPMorgan Chase, Bank of America, Merrill Lynch, etc. Given these investors' increasing concerns regarding the risks related to climate change, since its launch in 2000 the CDP sends out information requests on their behalf to public and private organisations throughout the world requesting them to report their greenhouse gas emissions and relevant management actions and policies. Companies are encouraged to use the Greenhouse Gas Protocol to calculate their specific emissions. All Signatory Investors have access to all company reports sent to the CDP, even if these are not publicly available. Internet: http://www.cdproject.net

CERES (Coalition for Environmentally Responsible Economies) is a US-based network of investors, environmental organisations and other public interest groups working with companies and investors to address sustainability challenges such as climate change. The coalition was founded in 1989, and its signatories share ten principles related to engagement in environmentally responsible and sustainable business solutions. As of mid 2009, the CERES Principles have been adopted by over 50 companies including a dozen that appear on the Fortune 500 list. Internet: http://www.ceres.org

Corporate capital structure refers to the way a corporation finances its assets, usually through a combination of equity (investment), debt (loans from financial institutions and other organisations, bonds, etc), or hybrid securities (bonds convertible into shares, etc).

Corporate loan is a loan provided to a corporation usually for unspecified purposes as opposed to project loans that form part of project finance aimed at implementation of specific projects. 
Corporate Social Responsibility (CSR) refers to the activities of companies that are specifically aimed at improving their ESG performance in a manner that extends beyond legislative requirements. Another definition of CSR is the provision of public goods by private entities. There are different types of CSR, and these can, according to the business strategist Michael Porter, be grouped into a) reactive CSR, which often equates to "giving away money" on the part of a company that suffers losses at a result of benefiting stakeholders, and b) strategic CSR, which creates "win-win" situations for both companies and the society through the generation of long-term shared value.

Ecological footprint represents human demand on the Earth's ecosystem goods and services to produce the resources that an individual, population or activity consumes, and to absorb the waste it generates. While the term "ecological footprint" is widely used, its methods of calculation and measurement may vary. WWF International publishes a biannual 'Living Planet Report' with updates on trends in changes of both biocapacity and ecological footprint, including the carbon and water footprint of nations. Internet: http://www.panda.org/livingplanet

Ecosystem goods and services include products such as clean drinking water and forestry products and processes such as the decomposition of wastes and mitigation of negative climate change impacts.

Emerging market economies (EMEs or emerging markets) is the term financial analysts use to describe a group of $20-30$ developing and transition countries, characterised by rapid growth of production, consumption and financial market capitalisation. These usually include the so-called BRICS (Brazil, Russia, India, China and South Africa), Indonesia, Malaysia, Mexico, Thailand, Turkey and a number of others.

Environment-intensive industries are sectors of the economy that rely directly or indirectly on natural resources such as mineral deposits, ecosystem goods and services and energy, and/or are significant polluters of the environment. Examples of environment-intensive industries include extraction of oil, gas, coal and metal ores, forestry, fishery, transport, construction, etc.

Environmental Impact Assessment (EIA) is the formal procedure of assessing the potential positive and negative environmental impacts of a particular project. EIA procedures can be established by national governments through relevant legislation, or by financial institutions and corporate entities for their own risk mitigation purposes. For example, Russia's monopoly gas producer, Gazprom, undertakes EIAs according to its own internal guidelines, the requirements of the Russian legislation, and the demands of international financial institutions (in cases where Gazprom applies for foreign project finance loans).

Equator Principles (EPs) is a voluntary benchmark for the financial industry to manage social and environmental issues in project finance transactions. Launched in 2003 by 10 banks in co-operation with the IFC, the Equator Principles were revised in July 2006 to make them applicable to all projects with a total cost higher than USD 10 million. In 2007, 71 percent of newly provided project finance in emerging markets (USD 53 billion out of a total of USD 75 billion) was subject to EPs. As of mid 2009, the EPs have been adopted by over 60 banks from around the world. Internet: http://www.equatorprinciples.com

Equity is the value of an ownership interest in property, and is synonymous with shares or stock in publicly listed companies. Equity comprises a portion of the corporate capital structure. 
Eurobond is an international bond that is denominated in a currency not native to the country in which it is issued. London is one of the principal centres of the Eurobond market, but Eurobonds may be traded throughout the world - for example in New York, Singapore or Tokyo.

Financial institution is an institution that provides financial services for its clients or members. Financial institutions include banks, insurance companies, pension funds, asset managers, mutual funds, hedge funds and a number of other institutional forms.

Footprint - see Ecological footprint.

Global Compact - see UN Global Compact.

Global Reporting Initiative (GRI) is the world's most widely used sustainability reporting framework that sets out the principles and indicators that organisations can use to measure and report their economic, environmental, and social performance. The GRI started off as a joint initiative by CERES and UNEP, but has been an independent entity since 2002. In 2006, the GRI entered into a strategic alliance with UN Global Compact, with GRI acting as a tool for implementing the Principles of the Global Compact. The cornerstone of the GRI is the Sustainability Reporting Guidelines, the third version of which - known as the G3 (Third Generation) Guidelines - was launched in October 2006. As of mid 2009, approximately 1500 companies have declared their adoption of the G3 reporting standard. http://www.globalreporting.org

'Green', as in 'green' component in an economic stimulus package, 'green' finance, etc, describes a product or an action which prevents or avoids harm to the environment (in the narrow sense) or promotes efficient use and conservation of natural resources (in the broad sense).

Institutional investor is a financial institution which pools large sums of money and invests these sums in companies. The notion comes from the fact that these investors are institutions as opposed to private individuals (who can also act as investors).

Investor Network on Climate Risk (INCR) is a US-based network of institutional investors and other financial institutions that promotes a better understanding of the financial risks and investment opportunities associated with climate change. INCR was launched in November 2003 and is coordinated by CERES. Its membership has grown from 10 investors managing USD 600 billion in assets in 2003 to more than 70 investors managing over USD 7 trillion in assets in 2009. Internet: http://www.incr.com

Leveraged loans refer to loans used to supplement investment as a source of funding for companies and projects.

Millennium Development Goals (MDGs) are eight international development goals that over 190 United Nations member states and over 20 international organisations have agreed to achieve by 2015 . These goals address, poverty, health, environmental, and gender issues and were agreed by the UN member states in 2001 as part of the Millennium Declaration of 2000 . Internet: http://www.un.org/millenniumgoals

Multilateral Development Banks (MDBs) are financial institutions created by a group of countries to provide financing and professional advice for the purpose of development. MDBs include the World Bank and Regional Development Banks. 
Natural capital is the land, air, water, living organisms and all formations of the Earth's biosphere that provide the ecosystem goods and services imperative for the survival and well-being of humankind and that form the basis for all human economic activity. While human, financial and technological capitals have traditionally been used as a measure of economic performance, natural capital has in general been ignored. A new generation of development indicators (known as "full-cost" or "beyond GDP" approaches) takes account of natural capital in order to enable decision-making that promotes effective management, preservation and enhancement of natural environments.

Non-Governmental Organisation (NGO) is an organisation that is created by civil society and is not part of the public or private sectors.

Organisation of Economic Cooperation and Development (OECD), established in 1961, consists of 30 developed economies: namely Australia, Austria, Belgium, Canada, the Czech Republic, Denmark, Finland, France, Germany, Greece, Hungary, Iceland, Ireland, Italy, Japan, Luxembourg, Mexico, the Netherlands, New Zealand, Norway, Poland, Portugal, the Slovak Republic, South Korea, Spain, Sweden, Switzerland, Turkey, the United Kingdom, and the United States. In May 2007, the OECD countries agreed to invite Chile, Estonia, Israel, Russia and Slovenia to begin discussions regarding membership of the Organisation and offered enhanced engagement, with a view to possible membership, to Brazil, China, India, Indonesia and South Africa. OCED membership requires, amongst other considerations, application of sound environmental policies by the candidate country, which also serve as one of the referral standards for the Equator Principles. Export credit agencies of the OECD countries fulfil the "Recommendation on Common Approaches on the Environment and Officially Supported Export Credits" guidelines. Internet: http://www.oecd.org

Private equity consists of equity securities in operating companies that are not publicly traded on a stock exchange.

Project finance is a method of funding in which the lender considers primarily the revenues generated by a single project, both as the source of repayment and as security for the exposure. This type of financing is an alternative to corporate loans provided to corporations, usually for unspecified purposes. As a rule, project finance is employed for large, complex and expensive installations that might include for example power plants, chemical processing plants, mines, transportation infrastructure, and telecommunications infrastructure. The borrower is usually a Special Purpose Entity (SPE) that is not permitted to perform any function other than developing, owning, and operating the installation.

Reactive CSR is a type of CSR which often equates to "giving away money" on the part of a company that suffers losses at a result of benefiting stakeholders. Reactive CSR often takes place ad hoc and includes such activities as charitable donations and coerced or PR-driven social and environmental investments aimed at mitigating harms from value-chain activities. An alternative type of CSR is strategic CSR.

Regional Development Banks (RDBs) include, but are not limited to the European Bank of Reconstruction and Development, African Development Bank, Asian Development Bank, Black Sea Trade and Development Bank, Inter-American Development Bank, Islamic Development Bank, etc.

Responsible finance has a broad and narrow scope in environmental and social terms. The former stands for recognition on the part of FIs of environmental and social risks associated with the projects and clients to which they provide funding, and operation of an adequate system to manage these risks. The narrow definition of responsible finance applies to FIs which specialise in financing socially and 
environmentally targeted projects such as social housing, energy efficiency, sanitation, etc, and which often provide loans to these projects at an interest rate lower than the average.

Stakeholders are individuals, groups and organisations who affect or can be affected by a company's activities. In environmental and social terms, the stakeholders of FIs include their owners (shareholders in case of publicly listed companies), clients, employees, and government agencies as well as any other parties that can be affected by their loan or investment activities.

Strategic CSR, as opposed to reactive CSR, is a type of CSR which creates "win-win" situations for both companies and the society through the generation of long-term shared value. Strategic CSR transforms value-chain activities to benefit society while reinforcing corporate strategy and leveraging capabilities that exist within companies to improve their competitiveness.

Sustainable development (sustainability) is development that meets the need of the present without compromising the ability of future generations to meet their own needs (as defined by the UN's Bruntland Commission).

Sustainable finance is finance employed to achieve the goals of sustainable development, including the Millennium Development Goals.

Syndicated loans are large loans in which a group of banks provide funds for a borrower or borrowers. The primary motivation for such loan syndication is risk mitigation for the lenders. Syndicated loans involve one or more mandated lead arrangers and up to $20-30$ associated lenders.

United Nations Environment Programme (UNEP) coordinates the environmental activities of the United Nations and encourages sustainable development through the application of sound environmental practices. It was founded as a result of the United Nations Conference on the Human Environment in June 1972 and has its headquarters in Nairobi, Kenya. UNEP also has six regional offices and various country offices. Internet: http://unep.org

UNEP Financial Initiative (UNEP FI) is a global partnership between $U N E P$ and the financial sector, represented by more than 170 signatories as of mid 2009, comprised primarily of banks and insurance companies. UNEP FI's mission is to identify, promote, and realise the adoption of environmental and sustainability best practice at all levels of financial institution operations. Internet: http://www.unepfi.org

UN Global Compact (UNGC) is a United Nations initiative aimed at encouraging businesses across the globe to adopt sustainable and socially responsible policies, and to report on the implementation of these policies in support of broader UN goals such as the Millennium Development Goals. The Global Compact's participants voluntarily commit to comply with ten principles in the areas of human rights, labour, anti-corruption and the environment. Since its official launch on 26 July 2000, the initiative has grown to include more than 6700 participants as of Oct. 2009, including over 5200 businesses in 130 countries (as of mid 2009). In 2006 the UNGC entered into a strategic alliance with the GRI, in which the GRI acts as a tool for implementing the UNGC Principles. Internet: http://www.unglobalcompact.org

United Nations Principles for Responsible Investment (UN PRI) were launched in 2006, as a result of a joint effort by UNEP FI and the UN Global Compact, based on an initiative of former UN Secretary-General Kofi Anan. The UN PRI focus on promoting ESG issues in equity and investment funds. Signatories to the UN PRI commit to making ESG issues a central component of their analysis of 
potential investments and to incorporating ESG issues into their own operations. As of mid 2009, the UN PRI have been adopted by over 510 FIs with total assets under management of over USD 18 trillion. An increasing number of institutional asset owners include UN PRI membership as part of their fund manager selection criteria.

Value at Risk refers to the risk embedded in a financial institution's current asset base and business strategies associated with regulatory change, legacy assets, market disruption and emerging trends. These risks may crystallise within a relatively short time frame and "peak", for example, as the world responds to the climate change through carbon emissions restrictions. Unless these issues are considered seriously by financial institutions, they may negatively contribute to overall credit risks. Appropriate responses from financial institutions can lead to a significant reduction in the risk inherent in a client, industry or financial portfolio.

Value at Stake is the emerging opportunity associated with new business drivers, changing client demand, regulatory obligations and expanded geographic scope of business activities. This may offer significant long-term revenue potential for a financial institution and its clients, in which they can capitalise on opportunities that arise. Examples include assisting in and funding of clients transition to a low carbon economy.

World Bank is an international financial institution that provides leveraged loans to emerging market economies and other developing countries for capital programs with a primary objective of poverty alleviation. The World Bank is therefore involved into funding of a wide range of projects requiring EIAs. The World Bank comprises two institutions - the International Bank for Reconstruction and Development (IBRD) and the International Development Association (IDA). Internet: http://www.worldbank.org

World Bank Group (WBG) is a family of five international organisations that finance poverty alleviation in emerging market economies and other developing countries. Two of these organisations the International Bank for Reconstruction and Development (IBRD) and the International Development Association (IDA) - make up the World Bank, while the other three are the International Finance Corporation (IFC), the Multilateral Investment Guarantee Agency (MIGA) and the International Centre for Settlement of Investment Disputes (ICSID). Internet: http://www.worldbank.org 


\section{Collevecchio Declaration on Financial Institutions and Sustainability ${ }^{53}$}

Financial institutions (FIs) can and must play a positive role in advancing environmental and social sustainability. This declaration, endorsed by over 200 civil society organisations, calls on FIs to embrace six commitments, and take immediate steps to implement them as a way for FIs to retain their social license to operate. These commitments reflect civil society's expectations of the role and responsibilities of the financial services sector in fostering sustainability.

\section{THE ROLE AND RESPONSIBILITY OF FINANCIAL INSTITUTIONS}

The financial sector's role of facilitating and managing capital is important; and finance, like communications or technology, is not inherently at odds with sustainability. However, in the current context of globalization, financial institutions (FIs) play key roles in channelling financial flows, creating financial markets and influencing international policies in ways that are too often unaccountable to citizens, and harmful to the environment, human rights, and social equity.

FIs have played a role in irresponsibly channelling money to unethical companies, corrupt governments, and egregious projects. In the Global South, FIs' increasing role in development finance has meant that they bear significant responsibility for international financial crises, and the crushing burden of developing country debt. However, most FIs do not accept responsibility for the environmental and social harm created by their transactions, even though they may be eager to take credit for the economic development and benefits derived from their services. And relatively few FIs, in their role as creditors, analysts, underwriters, advisers, or investors effectively use their power to deliberately channel finance into sustainable enterprises, or encourage their clients to embrace sustainability.

Similarly, the vast majority of FIs do not play a proactive role in creating financial markets that value communities and the environment. As companies FIs concentrate on maximizing shareholder value, while as financiers they seek to maximize profit; this dual role means that FIs have played a pivotal role in creating financial markets that predominantly value short-term returns. These brief time horizons create intense pressure for companies to put short-term profits before longer-term sustainability goals, such as social stability and ecological health.

Finally, through the work of international public policy bodies such as the Bretton Woods institutions, the power of FIs has increasingly expanded as countries have deregulated, liberalized, and privatized their economies and financial markets. Financial institutions have not only actively promoted these policies and processes, but they have benefited from them through increased profit and influence.

In too many cases, FIs have unfairly benefited at the expense of communities and the environment. For example, during financial crises, many FIs charged high risk premiums to indebted countries, while at the same time benefiting from public bail-outs. Some FIs have spoken out against innovative solutions to the debt crisis, such as the sovereign-debt restructuring processes proposed by civil society groups and now being discussed in the International Monetary Fund. And FIs' voices have been absent in efforts to address tax havens, a problem that blocks progress towards equity and sustainability.

As a result, civil society is increasingly questioning the financial sector's accountability and responsibility, and challenging FIs' social license to operate. As major actors in the global economy, FIs should embrace a commitment to sustainability that reflects best practice from alone are not sufficient, and that they must support regulations that will help the sector advance sustainability.

\section{SIX COMMITMENTS TO KEY PRINCIPLES}

\footnotetext{
53 The Collevecchio Declaration was signed in January 2003. Downloadable in English at http://www.banktrack.org/download/collevecchio_declaration_2/0 030401_collevecchio_declaration.pdf (accessed on 30 Oct. 2009)
} 
Acknowledging that FIs, like all corporations, exist as creations of society to act in the public interest, FIs should promote the restoration and protection of the environment, and promote universal human rights and social justice. These principles should be inherent in the way that they offer financial products and services, and conduct their businesses.

Finance and commerce has been at the centre of a historic detachment between the world's natural resource base, production and consumption. As we reach the boundaries of the ecological limits upon which all commerce relies, the financial sector should take its share of responsibility for reversing the effects this detachment has produced. Thus, an appropriate goal of FIs should be the advancement of environmental protection and social justice rather than solely the maximization of financial return. To achieve this goal, FIs should embrace the following six commitments:

\section{Commitment to Sustainability}

FIs must expand their missions from ones that prioritize profit maximization to a vision of social and environmental sustainability. A commitment to sustainability would require FIs to fully integrate the consideration of ecological limits, social equity and economic justice into corporate strategies and core business areas (including credit, investing, underwriting, advising), to put sustainability objectives on an equal footing to shareholder maximization and client satisfaction, and to actively strive to finance transactions that promote sustainability.

\section{Commitment to 'Do No Harm'}

FIs should commit to do no harm by preventing and minimizing the environmentally and/or socially detrimental impacts of their portfolios and their operations. FIs should create policies, procedures and standards based on the Precautionary Principle to minimize environmental and social harm, improve social and environmental conditions where they and their clients operate, and avoid involvement in transactions that undermine sustainability.

\section{Commitment to Responsibility.}

FIs should bear full responsibility for the environmental and social impacts of their transactions. FIs must also pay their full and fair share of the risks they accept and create. This includes financial risks, as well as social and environmental costs that are borne by communities.

\section{Commitment to Accountability}

FIs must be accountable to their stakeholders, particularly those that are affected by the companies and activities they finance. Accountability means that stakeholders must have an influential voice in financial decisions that affect the quality of their environments and their lives - both through ensuring that stakeholders rights are protected by law, and through practices and procedures adopted by FIs themselves.

\section{Commitment to Transparency}

FIs must be transparent to stakeholders, not only through robust, regular and standardized disclosure, but also by being responsive to stakeholder needs for specialized information on FIs' policies, procedures and transactions. Commercial confidentiality should not be used as an excuse to deny stakeholders information.

\section{Commitment to Sustainable Markets and Governance}

FIs should ensure that markets are more capable of fostering sustainability by actively supporting public policy, regulatory and/or market mechanisms which facilitate sustainability and that foster the full cost accounting of social and environmental externalities.

\section{IMPLEMENTING THE COLLEVECCHIO DECLARATION}


This document provides guidance for financial institutions (FIs) on implementing the Collevecchio Declaration on Financial Institutions and Sustainability. The Declaration calls for broad commitments, and FIs may have differing interpretations regarding how to implement them. This document provides clarification of what civil society currently (2003) expects from FIs committed to implementing the six key principles of the Collevecchio Declaration.

FIs can work with stakeholders to take the following immediate steps:

\section{Commitment to Sustainability}

a) Measurement of environmental and social impacts

FIs should measure the environmental and social impacts of their portfolios in core business areas, including lending, investing, underwriting and advising.

\section{b) Continuous improvement based on environmental \& social impacts of portfolios}

Although some FIs embrace the concept of continuously improving their management systems, all FIs must assess the sustainability challenges and issues facing their portfolios; and create objectives, strategies, timetables and performance indicators to increase the sustainability profile of their portfolios.

\section{c) Fostering sustainability}

FIs must actively seek to shift their businesses to proactively sustainable practices which improve environmental and social conditions. This might include, for example, reducing the carbon footprint of their portfolios by shifting investments from fossil fuel to renewables; or the capitalization of sustainable enterprises. FIs should use their influence to ensure that companies and projects in which they invest or support act in line with best practice. FI should set clear timetables for improving their clients' sustainability performance, and if necessary, withdraw their support of non-performing clients.

\section{d) Implementation and capacity building}

FIs should take all necessary steps to ensure that staff are trained and capacity is built to ensure that sustainability objectives are met and that procedures, policies and standards are implemented. Staff performance reviews and bonuses should be linked to the achievement of sustainability targets and timetables.

\section{Commitment to 'Do No Harm'}

\section{a) Sustainability procedures}

On the basis of the Precautionary Principle, FIs should create transactions-based procedures that screen and categorize potential deals on the basis of environmental and social sensitivity. Based on a transaction's sensitivity, the FI should perform appropriate levels of due diligence, stakeholder consultation, and assessment. FIs should also create processes for influencing, legally enforcing and monitoring sensitive transactions.

\section{b) Sustainability standards}

FIs should adopt internationally recognized, sector-specific, best practice standards that can serve as the basis for financing or refusing to finance a transaction (e.g. World Commission on Dams guidelines, Forest Stewardship Council standards)

Banks should also establish supplementary sectoral standards with stakeholder input and guidance. Some such standards exist already for the forests sector and others are being developed for other issues/sectors such as Minerals and Dams projects. These standards will vary, but should as a minimum cover issues such as: respect for international conventions, no-go zones, gender equity issues, supply chain issues, human rights, etc.

\section{Commitment to Responsibility}




\section{a) Bear full responsibility for the impacts of transactions}

FIs must pay for their full and fair share of risks that they accept and create. This means FIs should not help engineer country bail-out packages that aggravate the debt burden of developing countries. It also means that FIs should bear full responsibility for the environmental and social costs that are created by their transactions but borne by communities. This includes using their influence and resources to address the needs of communities whose livelihoods and ways of life are compromised by the adverse environmental or social impacts of their transactions.

\section{b) Recognize their role in developing country debt crisis}

FIs should recognize that the ability of countries to service external debt depends on the maintenance of social and ecological systems, and that developing country debt burdens are socially, environmentally, and economically unsustainable. FIs should refrain from lobbying against innovative solutions to the developing country debt crisis, and support calls for significant debt relief/cancellation.

\section{Commitment to Accountability}

\section{a) Public Consultation}

FIs can advance accountability by consulting civil society groups when creating sustainability policies, objectives, procedures, and standards. FIs should incorporate the views of stakeholders affected by their credit, lending, underwriting or advisory functions. This includes respecting the right of affected communities to "say no" to a transaction.

\section{b) Stakeholder Rights}

FIs must also support regulatory efforts that increase the rights of stakeholders in having a more influential voice in the governance of FIs and their transactions.

\section{Commitment to Transparency}

a) Corporate Sustainability Reporting

FIs should publish annual sustainability reports according to an internationally recognized reporting format supported by civil society. FIs should further include disclosure on the sustainability profile of the FI's portfolio, a breakdown of core business activities by sector and region, and the implementation of the FI's sustainability policies and objectives.

\section{b) Information Disclosure}

FIs should make assumptions in favour of information disclosure. Particularly for completed transactions, but also for those in the pipeline, FIs should publicly provide information on companies and significant transactions in a timely manner, and not hide behind the excuse of business confidentiality.

\section{Commitment to Sustainable Markets and Governance.}

\section{a) Public policy and regulation}

FIs must recognise the role that governments must play in setting the market frameworks within which companies and FIs function. FIs should work to make markets are more capable of fostering sustainability by actively supporting public policy, regulatory or market mechanisms that foster the internalisation of social and environmental externalities.

\section{b) Financial practices}

FIs should avoid and discourage inappropriate use of tax havens or currency speculation that are unfair and that create instability. FIs should also strive to make financial decisions based on longer-term time horizons and reward clients that do the same. 


\section{The Equator Principles (revised text of July 2006) ${ }^{54}$ PREAMBLE}

Project financing, a method of funding in which the lender looks primarily to the revenues generated by a single project both as the source of repayment and as security for the exposure, plays an important role in financing development throughout the world. ${ }^{55}$ Project financiers may encounter social and environmental issues that are both complex and challenging, particularly with respect to projects in the emerging markets.

The Equator Principles Financial Institutions (EPFIs) have consequently adopted these Principles in order to ensure that the projects we finance are developed in a manner that is socially responsible and reflect sound environmental management practices. By doing so, negative impacts on project-affected ecosystems and communities should be avoided where possible, and if these impacts are unavoidable, they should be reduced, mitigated and/or compensated for appropriately. We believe that adoption of and adherence to these Principles offers significant benefits to ourselves, our borrowers and local stakeholders through our borrowers' engagement with locally affected communities. We therefore recognise that our role as financiers affords us opportunities to promote responsible environmental stewardship and socially responsible development. As such, EPFIs will consider reviewing these Principles from time-to-time based on implementation experience, and in order to reflect ongoing learning and emerging good practice.

These Principles are intended to serve as a common baseline and framework for the implementation by each EPFI of its own internal social and environmental policies, procedures and standards related to its project financing activities. We will not provide loans to projects where the borrower will not or is unable to comply with our respective social and environmental policies and procedures that implement the Equator Principles.

\section{SCOPE}

The Principles apply to all new project financings globally with total project capital costs of US\$10 million or more, and across all industry sectors. In addition, while the Principles are not intended to be applied retroactively, we will apply them to all project financings covering expansion or upgrade of an existing facility where changes in scale or scope may create significant environmental and/or social impacts, or significantly change the nature or degree of an existing impact.

The Principles also extend to project finance advisory activities. In these cases, EPFIs commit to make the client aware of the content, application and benefits of applying the Principles to the anticipated project, and request that the client communicate to the EPFI its intention to adhere to the requirements of the Principles when subsequently seeking financing.

\section{STATEMENT OF PRINCIPLES}

\footnotetext{
${ }^{54}$ Downloadable in English, French, Chinese, Japanese, Portuguese and Russian at http://www.equator-principles.com

55 Project finance is "a method of funding in which the lender looks primarily to the revenues generated by a single project, both as the source of repayment and as security for the exposure. This type of financing is usually for large, complex and expensive installations that might include, for example, power plants, chemical processing plants, mines, transportation infrastructure, environment, and telecommunications infrastructure. Project finance may take the form of financing of the construction of a new capital installation, or refinancing of an existing installation, with or without improvements. In such transactions, the lender is usually paid solely or almost exclusively out of the money generated by the contracts for the facility's output, such as the electricity sold by a power plant. The borrower is usually an SPE (Special Purpose Entity) that is not permitted to perform any function other than developing, owning, and operating the installation. The consequence is that repayment depends primarily on the project's cash flow and on the collateral value of the project's assets." (Basel Committee on Banking Supervision, International Convergence of Capital Measurement and Capital Standards ("Basel II")).
} 
EPFIs will only provide loans to projects that conform to Principles 1-9 below:

\section{Principle 1: Review and Categorisation}

When a project is proposed for financing, the EPFI will, as part of its internal social and environmental review and due diligence, categorise such project based on the magnitude of its potential impacts and risks in accordance with the environmental and social screening criteria of the International Finance Corporation (IFC) (Exhibit I).

\section{Principle 2: Social and Environmental Assessment}

For each project assessed as being either Category A or Category B, the borrower has conducted a Social and Environmental Assessment ("Assessment") process ${ }^{56}$ to address, as appropriate and to the EPFI's satisfaction, the relevant social and environmental impacts and risks of the proposed project (which may include, if relevant, the illustrative list of issues as found in Exhibit II). The Assessment should also propose mitigation and management measures relevant and appropriate to the nature and scale of the proposed project.

\section{Principle 3: Applicable Social and Environmental Standards}

For projects located in non-OECD countries, and those located in OECD countries not designated as High-Income, as defined by the World Bank Development Indicators Database, the Assessment will refer to the then applicable IFC Performance Standards (Exhibit III) and the then applicable Industry Specific EHS Guidelines ("EHS Guidelines") (Exhibit IV). The Assessment will establish to a participating EPFI's satisfaction the project's overall compliance with, or justified deviation from, the respective Performance Standards and EHS Guidelines.

The regulatory, permitting and public comment process requirements in High-Income OECD Countries, as defined by the World Bank Development Indicators Database, generally meet or exceed the requirements of the IFC Performance Standards (Exhibit III) and EHS Guidelines (Exhibit IV). Consequently, to avoid duplication and streamline EPFI's review of these projects, successful completion of an Assessment (or its equivalent) process under and in compliance with local or national law in High-Income OECD Countries is considered to be an acceptable substitute for the IFC Performance Standards, EHS Guidelines and further requirements as detailed in Principles 4, 5 and 6 below. For these projects, however, the EPFI still categorises and reviews the project in accordance with Principles 1 and 2 above.

The Assessment process in both cases should address compliance with relevant host country laws, regulations and permits that pertain to social and environmental matters.

\section{Principle 4: Action Plan and Management System}

For all Category A and Category B projects located in non-OECD countries, and those located in OECD countries not designated as High-Income, as defined by the World Bank Development Indicators Database, the borrower has prepared an Action Plan (AP) ${ }^{57}$ which addresses the relevant findings, and

\footnotetext{
56 Social and Environmental Assessment is a process that determines the social and environmental impacts and risks (including labour, health, and safety) of a proposed project in its area of influence. For the purposes of Equator Principles compliance, this will be an adequate, accurate and objective evaluation and presentation of the issues, whether prepared by the borrower, consultants or external experts. Depending on the nature and scale of the project, the assessment document may comprise a full-scale social and environmental impact assessment, a limited or focused environmental or social assessment (e.g. audit), or straight-forward application of environmental siting, pollution standards, design criteria, or construction standards. One or more specialised studies may also need to be undertaken.

57 The Action Plan may range from a brief description of routine mitigation measures to a series of documents (e.g., resettlement action plan, indigenous peoples plan, emergency preparedness and response plan, decommissioning plan, etc). The level of detail and complexity of the Action Plan and the priority of the identified measures and actions will be
} 
draws on the conclusions of the Assessment. The AP will describe and prioritise the actions needed to implement mitigation measures, corrective actions and monitoring measures necessary to manage the impacts and risks identified in the Assessment. Borrowers will build on, maintain or establish a Social and Environmental Management System that addresses the management of these impacts, risks, and corrective actions required to comply with applicable host country social and environmental laws and regulations, and requirements of the applicable Performance Standards and EHS Guidelines, as defined in the AP.

For projects located in High-Income OECD countries, EPFIs may require development of an Action Plan based on relevant permitting and regulatory requirements, and as defined by host-country law.

\section{Principle 5: Consultation and Disclosure}

For all Category A and, as appropriate, Category B projects located in non-OECD countries, and those located in OECD countries not designated as High-Income, as defined by the World Bank Development Indicators Database, the government, borrower or third party expert has consulted with project affected communities in a structured and culturally appropriate manner. ${ }^{58}$ For projects with significant adverse impacts on affected communities, the process will ensure their free, prior and informed consultation and facilitate their informed participation as a means to establish, to the satisfaction of the EPFI, whether a project has adequately incorporated affected communities' concerns. ${ }^{59}$

In order to accomplish this, the Assessment documentation and AP, or non-technical summaries thereof, will be made available to the public by the borrower for a reasonable minimum period in the relevant local language and in a culturally appropriate manner. The borrower will take account of and document the process and results of the consultation, including any actions agreed resulting from the consultation. For projects with adverse social or environmental impacts, disclosure should occur early in the Assessment process and in any event before the project construction commences, and on an ongoing basis.

\section{Principle 6: Grievance Mechanism}

For all Category A and, as appropriate, Category B projects located in non-OECD countries, and those located in OECD countries not designated as High-Income, as defined by the World Bank Development Indicators Database, to ensure that consultation, disclosure and community engagement continues throughout construction and operation of the project, the borrower will, scaled to the risks and adverse impacts of the project, establish a grievance mechanism as part of the management system. This will allow the borrower to receive and facilitate resolution of concerns and grievances about the project's social and environmental performance raised by individuals or groups from among project-affected

commensurate with the project's potential impacts and risks. Consistent with Performance Standard 1, the internal Social and Environmental Management System will incorporate the following elements: (i) Social and Environmental Assessment; (ii) management program; (iii) organisational capacity; (iv) training; (v) community engagement; (vi) monitoring; and (vii) reporting.

58 Affected communities are communities of the local population within the project's area of influence who are likely to be adversely affected by the project. Where such consultation needs to be undertaken in a structured manner, EPFIs may require the preparation of a Public Consultation and Disclosure Plan (PCDP).

59 Consultation should be "free" (free of external manipulation, interference or coercion, and intimidation), "prior" (timely disclosure of information) and "informed" (relevant, understandable and accessible information), and apply to the entire project process and not to the early stages of the project alone. The borrower will tailor its consultation process to the language preferences of the affected communities, their decision-making processes, and the needs of disadvantaged or vulnerable groups. Consultation with Indigenous Peoples must conform to specific and detailed requirements as found in Performance Standard 7. Furthermore, the special rights of Indigenous Peoples as recognised by host-country legislation will need to be addressed. 
communities. The borrower will inform the affected communities about the mechanism in the course of its community engagement process and ensure that the mechanism addresses concerns promptly and transparently, in a culturally appropriate manner, and is readily accessible to all segments of the affected communities.

\section{Principle 7: Independent Review}

For all Category A projects and, as appropriate, for Category B projects, an independent social or environmental expert not directly associated with the borrower will review the Assessment, AP and consultation process documentation in order to assist EPFI's due diligence, and assess Equator Principles compliance.

\section{Principle 8: Covenants}

An important strength of the Principles is the incorporation of covenants linked to compliance. For Category A and B projects, the borrower will covenant in financing documentation:

a) to comply with all relevant host country social and environmental laws, regulations and permits in all material respects;

b) to comply with the AP (where applicable) during the construction and operation of the project in all material respects;

c) to provide periodic reports in a format agreed with EPFIs (with the frequency of these reports proportionate to the severity of impacts, or as required by law, but not less than annually), prepared by in-house staff or third party experts, that i) document compliance with the AP (where applicable), and ii) provide representation of compliance with relevant local, state and host country social and environmental laws, regulations and permits; and

d) to decommission the facilities, where applicable and appropriate, in accordance with an agreed decommissioning plan.

Where a borrower is not in compliance with its social and environmental covenants, EPFIs will work with the borrower to bring it back into compliance to the extent feasible, and if the borrower fails to reestablish compliance within an agreed grace period, EPFIs reserve the right to exercise remedies, as they consider appropriate.

\section{Principle 9: Independent Monitoring and Reporting}

To ensure ongoing monitoring and reporting over the life of the loan, EPFIs will, for all Category A projects, and as appropriate, for Category B projects, require appointment of an independent environmental and/or social expert, or require that the borrower retain qualified and experienced external experts to verify its monitoring information which would be shared with EPFIs.

\section{Principle 10: EPFI Reporting}

Each EPFI adopting the Equator Principles commits to report publicly at least annually about its Equator Principles implementation processes and experience, taking into account appropriate confidentiality considerations. $^{60}$

\section{DISCLAIMER}

The adopting EPFIs view these Principles as a financial industry benchmark for developing individual, internal social and environmental policies, procedures and practices. As with all internal policies, these Principles do not create any rights in, or liability to, any person, public or private. Institutions are

\footnotetext{
${ }^{60}$ Such reporting should at a minimum include the number of transactions screened by each EPFI, including the categorisation accorded to transactions (and may include a breakdown by sector or region), and information regarding implementation.
} 
adopting and implementing these Principles voluntarily and independently, without reliance on or recourse to IFC or the World Bank.

\section{Exhibit I: Categorisation of projects}

As part of their review of a project's expected social and environmental impacts, EPFIs use a system of social and environmental categorisation, based on IFC's environmental and social screening criteria, to reflect the magnitude of impacts understood as a result of assessment.

These categories are:

- Category A - Projects with potential significant adverse social or environmental impacts that are diverse, irreversible or unprecedented;

- Category B - Projects with potential limited adverse social or environmental impacts that are few in number, generally site-specific, largely reversible and readily addressed through mitigation measures; and

- Category C - Projects with minimal or no social or environmental impacts.

\section{Exhibit II:}

Illustrative list of potential social and environmental issues to be addressed in the Social and Environmental Assessment documentation

In the context of the business of the project, the Assessment documentation will address, where applicable, the following issues:

a) assessment of the baseline social and environmental conditions

b) consideration of feasible environmentally and socially preferable alternatives

c) requirements under host country laws and regulations, applicable international treaties and agreements

d) protection of human rights and community health, safety and security (including risks, impacts and management of project's use of security personnel)

e) protection of cultural property and heritage

f) protection and conservation of biodiversity, including endangered species and sensitive ecosystems in modified, natural and critical habitats, and identification of legally protected areas

g) sustainable management and use of renewable natural resources (including sustainable resource management through appropriate independent certification systems)

h) use and management of dangerous substances

i) major hazards assessment and management

j) labour issues (including the four core labour standards), and occupational health and safety

k) fire prevention and life safety

1) socio-economic impacts

m) land acquisition and involuntary resettlement

n) impacts on affected communities, and disadvantaged or vulnerable groups

o) impacts on indigenous peoples, and their unique cultural systems and values

p) cumulative impacts of existing projects, the proposed project, and anticipated future projects 
q) consultation and participation of affected parties in the design, review and implementation of the project

r) efficient production, delivery and use of energy

s) pollution prevention and waste minimisation, pollution controls (liquid effluents and air emissions) and solid and chemical waste management

Note: The above list is for illustrative purposes only. The Social and Environmental Assessment process of each project may or may not identify all issues noted above, or be relevant to every project.

\section{Exhibit III:}

\section{IFC Performance Standards on Social and Environmental Sustainability}

As of April 30, 2006, the following IFC Performance Standards were applicable:

- Performance Standard 1: Social \& Environmental Assessment \& Management System

- Performance Standard 2: Labour and Working Conditions

- Performance Standard 3: Pollution Prevention and Abatement

- Performance Standard 4: Community Health, Safety and Security

- Performance Standard 5: Land Acquisition and Involuntary Resettlement

- Performance Standard 6: Biodiversity Conservation and Sustainable Natural Resource Management

- Performance Standard 7: Indigenous Peoples

- Performance Standard 8: Cultural Heritage

Note: The IFC has developed a set of Guidance Notes to accompany each Performance Standard. While not formally adopting the Guidance Notes, EPFIs or borrowers may use the Guidance Notes as useful points of reference when seeking further guidance on or interpretation of the Performance Standards. The IFC Performance Standards, Guidance Notes and Industry Sector EHS Guidelines can be found at www.ifc.org/enviro

\section{Exhibit IV:}

\section{Industry-Specific Environmental, Health and Safety (EHS) Guidelines}

EPFIs will utilise the appropriate environmental, health and safety (EHS) guidelines used by IFC which are now in place, and as may be amended from time-to-time.

IFC is using two complementary sets of EHS Guidelines available at the IFC website (www.ifc.org/enviro). These sets consist of all the environmental guidelines contained in Part III of the World Bank's Pollution Prevention and Abatement Handbook (PPAH) which went into official use on July 1, 1998 and a series of environmental, health and safety guidelines published on the IFC website between 1991 and 2003. Ultimately new guidelines, incorporating the concepts of cleaner production and environmental management systems, will be written to replace this series of industry sector, PPAH and IFC guidelines.

Where no sector specific guideline exists for a particular project then the PPAH's General Environmental Guidelines and the IFC Occupational Health and Safety Guidelines (2003) are applied, with modifications as necessary to suit the project.*

The table below lists both the World Bank Guidelines and the IFC Guidelines as of March 1, 2006. 
World Bank and IFC Sector-Specific Guidelines

\begin{tabular}{|c|c|}
\hline Industry Specific EHS Guidelines: & World Bank Guidelines (PPAH) IFC Guidelines \\
\hline 1. Aluminum Manufacturing & 1. Airports \\
\hline 2. Base Metal and Iron Ore Mining & 2. Ceramic Tile Manufacturing \\
\hline 3. Breweries & 3. Construction Materials Plants \\
\hline 4. Cement Manufacturing & 4. Electric Power Transmission and Distribution \\
\hline 5. Chlor-Alkali Plants & 5. Fish Processing \\
\hline 6. Coal Mining and Production & 6. Food and Beverage Processing \\
\hline 7. Coke Manufacturing & 7. Forestry Operations: Logging \\
\hline 8. Copper Smelting & 8. Gas Terminal Systems \\
\hline 9. Dairy Industry & 9. Geothermal Projects \\
\hline 10. Dye Manufacturing & 10. Hazardous Materials Management \\
\hline 11. Electronics Manufacturing & 11. Health Care \\
\hline 12. Electroplating Industry & 12. Life \& Fire Safety \\
\hline 13. Foundries & 13. Occupational Health and Safety \\
\hline 14. Fruit and Vegetable Processing & 14. Office Buildings \\
\hline 15. General Environmental Guidelines & 15. Offshore Oil \& Gas \\
\hline 16. Glass Manufacturing & 16. Polychlorinated Biphenyls (PCBs) \\
\hline 17. Industrial Estates & 17. Pesticide Handling and Application \\
\hline 18. Iron and Steel Manufacturing & 18. Plantations \\
\hline 19. Lead and Zinc Smelting & 19. Port and Harbour Facilities \\
\hline 20. Meat Processing and Rendering & 20. Rail Transit Systems \\
\hline 21. Mini Steel Mills & 21. Roads and Highways \\
\hline 22. Mixed Fertilizer Plants & 22. Telecommunications \\
\hline 23. Monitoring & 23. Tourism and Hospitality Development \\
\hline 24. Nickel Smelting and Refining & 24. Waste Management Facilities \\
\hline 25. Nitrogenous Fertilizer Plants & 25. Wastewater Reuse \\
\hline 26. Oil and Gas Development (Onshore) & 26. Wildland Management \\
\hline 27. Pesticides Formulation & 27. Wind Energy Conversion Systems \\
\hline 28. Pesticides Manufacturing & 28. Wood Products Industries \\
\hline 29. Petrochemicals Manufacturing & \\
\hline 30. Petroleum Refining & \\
\hline 31. Pharmaceutical Manufacturing & \\
\hline 32. Phosphate Fertilizer Plants & \\
\hline 33. Printing Industry & \\
\hline 34. Pulp and Paper Mills & \\
\hline 35. Sugar Manufacturing & \\
\hline 36. Tanning and Leather Finishing & \\
\hline 37. Textiles Industry & \\
\hline 38. Thermal Power Guidelines for New Plants & \\
\hline 39. Thermal Power Rehabilitation of Existing Plants & \\
\hline 40. Vegetable Oil Processing & \\
\hline 41. Wood Preserving Industry & \\
\hline
\end{tabular}

* Exception (the following are World Bank Guidelines not contained in the PPAH and currently in use)

Mining and Milling - Underground

Mining and Milling - Open Pit 


\section{Adopting and Implementing the Equator Principles: the Case of Mizuho Corporate Bank ${ }^{61}$}

\section{How Mizuho Corporate Bank implements the Equator Principles}

In October 2003, Mizuho Corporate Bank became the $18^{\text {th }}$ financial institution to sign the Equator Principles. It took us twelve months to prepare the implementation of the Principles. During this period, we translated IFC policies and guidelines into Japanese and prepared checklists for 38 industry sectors (with the IFC's pollution control limits and other IFC requirements). We created a manual and provided internal training, informed about our commitment on the Bank's website and in our corporate social responsibility report, and established a dialogue with NGOs.

All issues relating to the Equator Principles are centralized within Mizuho Corporate Bank's Sustainable Development Department, which was created in March 2006. This Department has six team members from four countries, including China. It works with 150 professionals in the Bank's project finance staff, located in our Tokyo headquarters and in five other countries. Based on information from the Business Promotion Division, we prepare an Equator screening report on individual transactions. This report is judged by the Credit Division as part of the credit approval process.

From April 2006 until March 2007, we screened 39 projects under the Equator Principles. Of these projects, one - a mining project - was considered a category A project, 37 were considered category $\mathrm{B}$ projects, and one, a category $\mathrm{C}$ project.

The Sustainable Development Department also entertains a dialogue with interested stakeholders. Since 2006, for example, it has given presentations at workshops and conferences organized by Chinese environmental NGOs, the China Enterprise Confederation, and the Chinese Banking Society.

In November 2006, Mizuho Corporate Bank became the secretariat bank for the EPFIs. As the secretariat bank, Mizuho is responsible for operating the official website of the Equator Principles and supports new EPFIs in their adopting process.

When Mizuho adopted the Equator Principles in 2003, we were ranked 18th among global banks in the project finance business, with transactions of about USD 1.1 billion. Since adopting the Principles, our ranking has steadily improved. In 2006, we were ranked 3rd, as the lead arranger of 54 deals with a total volume of more than USD 7.7 billion. The Equator Principles appear to have been a contributor to our increased success in the project finance business.

\section{A Case Study}

Tangguh LNG project is a prominent example of how the Equator Principles are being implemented in practice. Taking its name from the Indonesian word for "resilient", Tangguh is centered on the Bintuni Bay area of Papua - 3,200 kilometres from Jakarta. It involves two offshore platforms located in Bintuni Bay sub-sea pipelines, and a Liquefied Natural Gas (LNG) processing facility and tanker terminal on the south shore, scheduled to begin commercial operations in 2009. It costs USD 7 billion dollars and the loans to this project were provided in July 2006.

\footnotetext{
61 This business case has been sourced from the article prepared by Mr. Osamu Odawara, Senior Vice President and Head of the Sustainable Development Department at the Mizuho Corporate Bank: Odawara, O. The Equator Principles - a Framework for Managing Social and Environmental Risk in Project Finance / International Rivers Network (2008). 'New Financiers and the Environment: Ten Perspectives on How Financial Institutions Can Protect the Environment.' International Rivers Network, Berkeley. Pp. 26 - 27. http://www.esocialsciences.com/data/articles/Document11102009360.3584864.pdf (accessed on 30 Oct. 2009)
} 
Mizuho has categorized the Tangguh LNG project as A, because it has significant impacts on Biodiversity, Natural Habitat, and Local Communities including Indigenous People and Involuntary Resettlement. All of the IFC Performance Standards and IFC EHS Guidelines for three industrial sectors were applied to this project.

The LNG facilities are designed to meet the requirements of Indonesian Environmental Law and the IFC EHS Guidelines. The Project's Biodiversity programs provided valuable baseline information on the Bintuni Bay environment such as the fishery study and mangrove management study. Based on the study, the project has chosen the horizontal directional drilling method for pipeline construction at the offshore pipelines landfall to minimize impacts on mangroves. This method meets the requirements of the IFC Performance Standard for Biodiversity Conservation.

Equator banks also have to check the social impacts of the project. The Bintuni Bay area is sparsely populated by indigenous communities, living in numerous small villages. The local people have long been practicing agriculture, sago cultivation and fishing. Of these villages, the project identified eight villages as Directly Affected Villages including two Resettlement Affected Villages on the south shore, which are a resettlement village and a host village.

Villagers on the north shore of the bay were jealous of new houses provided for the resettlement affected villages. They believe the gas field in the bay also belongs to them under their own customs. The project created a system of Indigenous Peoples and the Integrated Social Programs and a Land Acquisition and Resettlement Action Plan for these villages. The project has been making efforts to ease tensions among the villages by these plans. Equator banks have been monitoring the implementation of these action plans.

The project is facing another challenge in the resettlement village. This project is going to hand over land titles for households and community assets. Community assets include the structures and land for village office, educational facilities, mosques and power and water utilities. The challenge is avoiding the risk of dependency, and keeping to a timetable for hand-over. Village people are becoming dependent on the project due to long running subsidies for assets and utilities, and do not like to assume the obligation for their operation, maintenance and repair. 


\section{About the Authors}

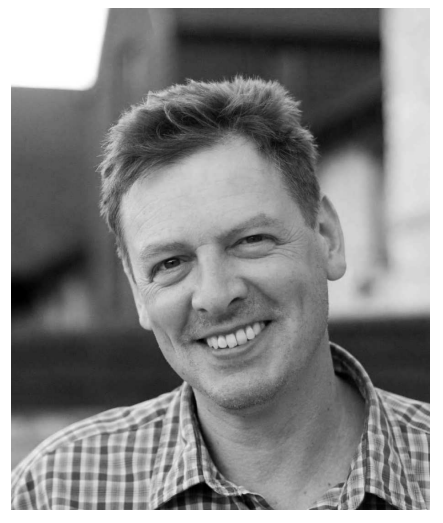

MARK ECKSTEIN is Managing Director of International Finance at WWF-US. He has over 20 years experience in developing sustainable development for financial institutions, private companies and government. His work at WWF has included capacity building and advisory work with a range of Chinese financial institutions and regulators, as well as WWF Financial Sector partners. He worked for IFC for seven years, during which time he was responsible for Environmental and Social due diligence as well as policy and procedures development. More recently (with Sustainable Finance Ltd) he has worked with a range of financial institutions (including DEG, FMO, ANZ, Citigroup, JPMorgan, Goldman Sachs and others) on the development of environmental and social management procedures and processes. He has trained over 500 financial institution staff on the Equator Principles/ IFC Performance Standards.

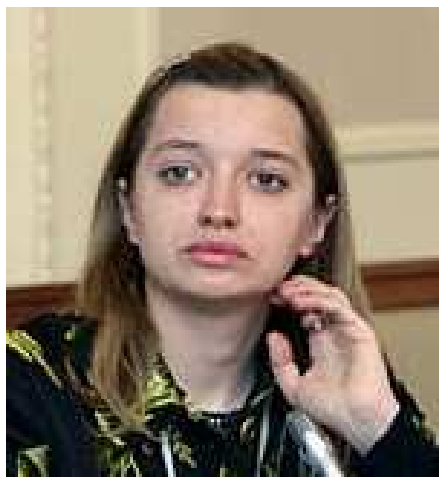

IVETTA GERASIMCHUK is Senior Advisor of the Trade and Investment Programme at WWF-Russia. She has more than ten years of experience in research and applied work on issues related to international development, economic policy and the environment. Prior to joining WWF-Russia, she carried out research for the Moscow State Institute of International Relations (MGIMO), from which she also holds her $\mathrm{PhD}$ degree in International Economics (Candidate of Sciences, 2006), as well as the Institute for African Studies of the Russian Academy of Sciences, the Centre for Current Politics of Russia, the Australian Embassy in Moscow, Kommersant Daily and a number of other leading business periodicals. She has authored over 50 publications on issues of environmental management and policy, including three monographs.

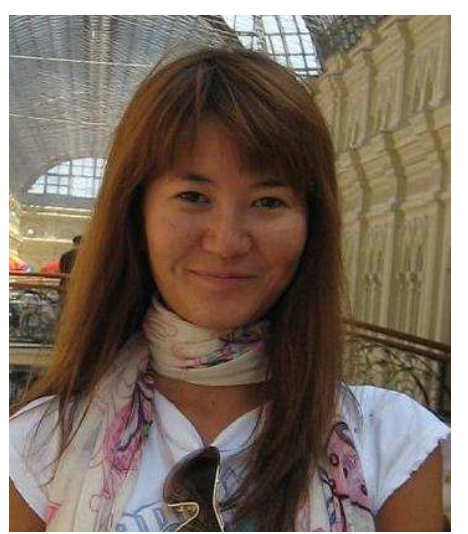

KAMILA ILYUMZHINOVA is Advisor of the Trade and Investment Programme at WWF-Russia. She has previously worked as an analyst in some of the world's largest financial institutions - Barclays (London, UK) and JPMorgan (London, UK). Subsequently, as the Coordinator of the Sustainable Lending Project at WWF-Russia she has been promoting, inter alia, initiatives such as Russian companies' reporting to the Carbon Disclosure Project. She received her BSc (Honours) degree in Investment and Financial Risk Management from the Cass Business School (London, UK) and is currently enrolled in the Master of Public Management programme at SDA Bocconi, Milan, Italy, from which she expects to graduate in 2010.

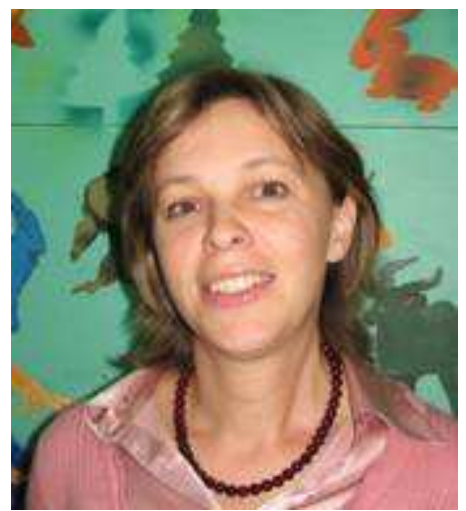

EKATERINA KHMELEVA is Environmental Law Advisor at WWFRussia. She has been working with environmental NGOs since 1992, including twelve years of experience in environmental law and litigation practice in protecting the environmental rights of citizens. Her other sphere of interest is the protection of indigenous peoples' rights to their traditional way of life and use of natural resources. She holds a $\mathrm{PhD}$ degree in Environmental Law (Candidate of Sciences, 1997) from the Institute of State and Law of the Russian Academy of Sciences. She is an author of over 20 academic and educational publications, including manuals for citizens and NGOs on court defense of environmental rights, access to information, and protection of indigenous peoples' rights. She is also one of the founders (in 1999) of the public interest law firm Rodnik. 


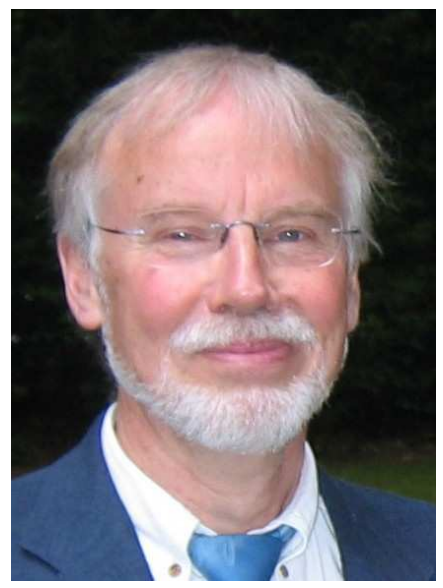

GEORG KRAFT is Managing Board Member of the Friedrichsdorfer Institut zur Nachhaltigkeit (IzN) e.V. He has 30 years of professional experience in investment management at German industrial companies and as a staff member of KfW, the German development bank. At KfW he was Senior Environmental Advisor to the Board of Management responsible for design and implementation of green credit lines with special focus on cleaner production, renewable energies and energy performance of buildings, environmental impact assessment of projects financed by $\mathrm{KfW}$ in Asia, Africa, Central and South America, financing projects for nature conservation and environmental protection. His tasks included appraisal, monitoring and evaluation of investment projects in various sectors such as small and medium industries, fertiliser, pulp and paper, hydropower, coalbased power plants, mining, roads and nature conservation projects.

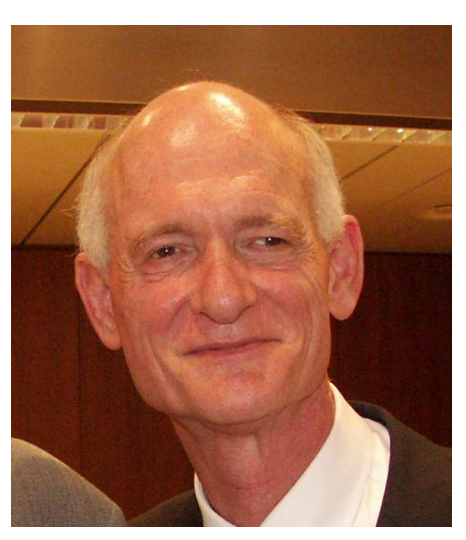

KfW Group in Frankfurt.

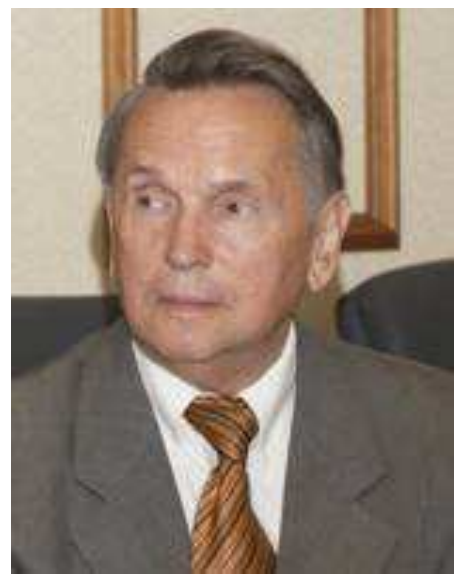

JÜRGEN LOTTMANN is Member of the Friedrichsdorfer Institut zur Nachhaltigkeit (IzN) e.V. and independent consultant in the fields of environment, energy and finance, working for clients in Germany and across the globe on issues such as environmental assessment of hydro and other power plants, development of bioenergy, industrial pollution control, adaptation to climate change, river basin management and accession to the environmental acquis communautaire of the EU. The main stations of his professional career in the field of environment have included his offices of Secretary General of the German Council of Environmental Advisors (Sachverständigenrat für Umweltfragen), Division Chief in the Ministry of Environment of the State of Hesse, and Chief Environmental Officer of

RENAT PERELET is Leading Research Fellow at the Institute for Systems Analysis of the Russian Academy of Sciences, and holds a $\mathrm{PhD}$ degree in Economics (Candidate of Sciences, 1971). His area of research and numerous publications is environmental economics and management, the economics of biodiversity and climate change. He worked for the United Nations Industrial Development Organisation (UNIDO) in the industrial management section responsible for Africa, Asia, Middle East, and Eastern Europe (1972-78). Subsequently, he served on the USSR Committee for UNEP (until 1985), and worked part time with the Moscow office of the Harvard University's Institute for International Development (1994-98). He was also Director of the Russian National Contact Point of the EU $6^{\text {th }}-7^{\text {th }}$ Framework R\&D Programmes (2003-07). He has served as a consultant for the Brundtland Commission (1984-97), UN ECE, UNESCO, UNDP, FAO, WWF, IUCN and other organisations. He also has been a member of a wide range of public and private sector advisory bodies in Russia, other CIS countries, and internationally.

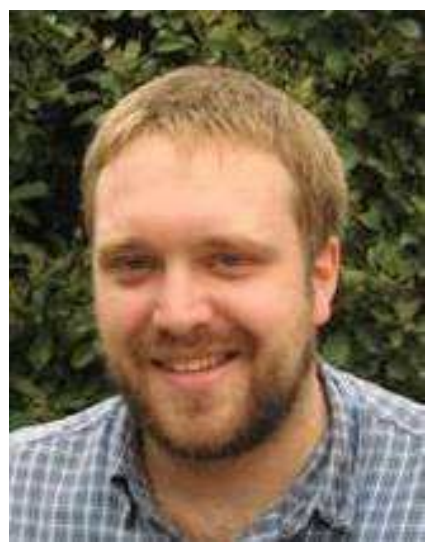

KEVIN SMITH is a freelance researcher and consultant with the Friedrichsdorfer Institut zur Nachhaltigkeit (IzN) e.V. This engagement has seen him travel to Russia, China and India to investigate the environmental sustainability of projects receiving loans from the German banking sector and the issue of energy efficiency in buildings. He holds a Bachelor degree in Development Studies from the University of East Anglia (UK). 


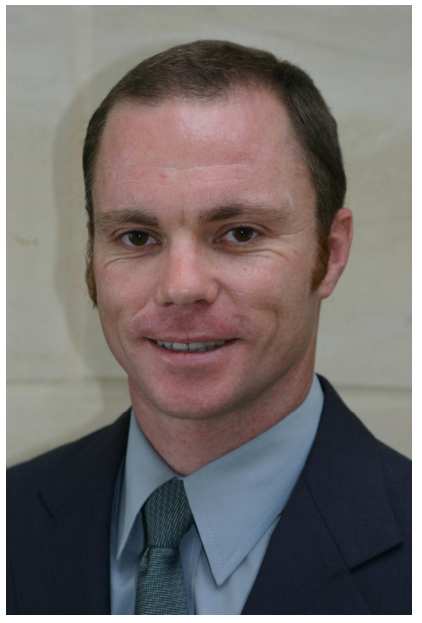

ALISTAIR SCHORN is Executive Manager of the WWF Trade and Investment Programme (TIP), which is responsible for promoting environmentally sound finance and business approaches in Russia, India and South Africa. Prior to joining WWF, he spent ten years at the South African Department of Trade and Industry, working in export and investment promotion. During this period, he served as Trade Commissioner at the South African Consulate General in Mumbai, India from 2001 - 2004. He has been the co-author and editor of various TIP publications, including a series of Corporate Social Responsibility reports for India, Russia, South Africa and the UAE, as well as reports on the subject of inward investment into Africa and bilateral investment between Russia and Africa. In addition, as an accomplished underwater photographer, he has had articles and photographs published in a number of South African outdoor and diving magazines. He holds a Masters Degree in International Economics from the University of Pretoria (South Africa).

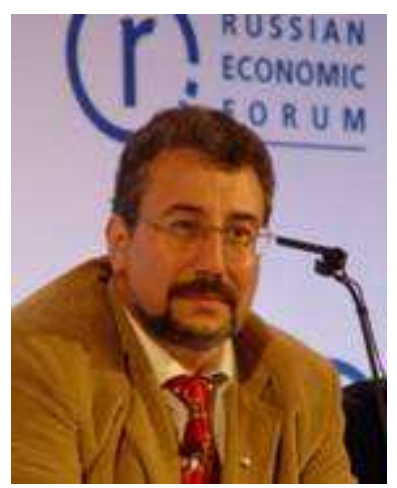

EVGENY SHVARTS is Director of Conservation Policy of WWF-Russia. He holds a $\mathrm{PhD}$ degree (Candidate of Sciences, 1987) and a Habilitation degree (Doctor of Sciences, 2003) in Geography. Prior to joining WWF-Russia, he was Senior Research Fellow and Member of the Academic Council of the Institute of Geography of the Russian Academy of Sciences (1990-98), founder and Chairman of the Board of the Biodiversity Conservation Center (1992-98), Manager of the Protected Areas Component of the GEF/World Bank "Russian Federation Biodiversity Conservation Project" (1996-98) and Co-Chairman of the International Socio-Ecological Union (1987-88, 1997-99). He has authored three books and more than 120 articles on issues of community ecology, biogeography, natural resource management, environmental policies and application of voluntary environmental commitments and certifications of business as a toolkit to raise the competitiveness of the Russian national economy and individual companies. In 2006 he received the "Distinguished Public Figure of Nature Conservation" title and honorary mark from the Russian Ministry of Natural Resources. 
[Pure Profit for Russia: Benefits of Responsible Finance]

WWF-Russia

http://www.wwf.ru

WWF-Germany

http://www.wwf.de

WWF-South Africa

http://www.wwf.org.za

WWF's mission is to stop the degradation of the planet's natural environment and to build a future in which humans live in harmony with nature, by:

- conserving the world's biological diversity

- ensuring that the use of renewable natural resources is sustainable

- promoting the reduction of pollution and wasteful consumption. 